\title{
Corporate cash shortfalls and financing decisions
}

\author{
Rongbing Huang and Jay R. Ritter*
}

August 31, 2017

\begin{abstract}
Firms raise external funds largely because they are squeezed for cash. Immediate cash needs, measured either ex post or ex ante, are the primary predictor for net debt issuances and a highly important predictor for net equity issuances. Furthermore, net debt issuers immediately spend almost all of the proceeds, but net equity issuers save much of the proceeds. Conditional on issuing a security, proxies for firm fundamentals and market conditions are important in explaining the debt versus equity choice, even for firms that are running out of cash.
\end{abstract}

Key Words: Cash Holdings, Security Issuance, SEO, Financing Decision, Capital Structure, Market Timing, Precautionary Saving, Corporate Lifecycle, Financial Flexibility, Static Tradeoff JEL: G32 G14

\footnotetext{
${ }^{*}$ Huang is from the Coles College of Business, Kennesaw State University, Kennesaw, GA 30144. Huang can be reached at rhuang1@ kennesaw.edu. Ritter is from the Warrington College of Business Administration, University of Florida, Gainesville, FL 32611. Ritter can be reached at jay.ritter@ warrington.ufl.edu. We also thank Harry DeAngelo, Ning Gao (our FMA discussant), David McLean, and the participants at the University of Arkansas, Harbin Institute of Technology, Hong Kong University of Science \& Technology, Penn State, the University of Sussex, Tsinghua PBC, the 2015 FMA Annual Meeting, and the 2016 University of Ottawa's Telfer Accounting and Finance conference for useful comments.
} 


\section{Corporate cash shortfalls and financing decisions}

\section{Introduction}

In this paper, we address three questions. First, do firms that raise funds do so mainly when they are squeezed for cash, defined as running out of cash if they didn't do external financing? The answer is yes: $67.1 \%$ of issuers would have run out of cash before the end of their fiscal year. Among firms that are running out of cash, $81.1 \%$ conduct a significant issue of debt or equity, whereas only $12.7 \%$ of other firms do so. ${ }^{1}$ Second, conditional on a cash squeeze, what determines the choice between debt and equity financing? We find that many equity issuers could have issued debt instead, and accounting and valuation information reliably predicts the choice of debt vs. equity financing. Third, do firms save much of the proceeds from the debt or equity financing in the fiscal year in which the financing occurs? Our regression analysis shows that, on average, net debt issuers spend 85.9 cents of each dollar raised before the end of the fiscal year, and save only 14.1 cents in cash. On average, after excluding firms with less than \$200 million in assets, net equity issuers immediately spend only 59.4 cents of each dollar raised, and save 40.6 cents in cash. Among smaller firms that issue equity, the savings rate is even higher.

In an extensively cited paper, Welch (2004, p. 107) states that "corporate issuing motives themselves remain largely a mystery." We show that cash needs based on publicly available accounting information are able to strongly predict which corporations will do external financing, and accounting information and valuation factors are able to reliably predict whether debt or equity will be issued. Using either simple univariate sorts or multinomial logit regressions, we

\footnotetext{
${ }^{1}$ We examine net debt issue and net equity issue decisions rather than gross debt issue and gross equity issue decisions. Unless explicitly stated as otherwise, "equity issue" and "net equity issue" are used interchangeably, and "debt issue" and "net debt issue" are used interchangeably in this paper. We focus on "significant" net issues, defined as greater than $5 \%$ of assets and $3 \%$ of the market value of equity.
} 
show that a firm is more likely to issue next year if it is small (as measured by sales), young, and, most importantly, is squeezed for cash. An issuer is more likely to use equity rather than debt if it has low internal cash flow, is small, and has a high Tobin's Q.

Recently, the economic importance of near-term cash squeezes as a motivation for issuing securities has started to receive much-deserved attention. In an influential paper, DeAngelo, DeAngelo, and Stulz (2010), henceforth DDS, find that $62.6 \%$ of firms conducting seasoned equity offerings (SEOs) would have run out of cash by the end of the following year if they did not raise capital. DDS also document that many mature firms conduct an SEO, and many firms with good equity market timing opportunities do not conduct an SEO. They thus conclude that neither corporate lifecycle nor market timing theories are sufficient to explain SEO decisions. DDS also find that the likelihood of an SEO is much higher for young firms than for old firms, suggesting that the lifecycle effect is more important than the timing effect. Taking their findings together, DDS conclude that "a near-term cash need is the primary SEO motive, with market-timing opportunities and lifecycle stage exerting only ancillary influences." We extend their analysis of SEOs to include other equity issues and debt financing, and find that a near-term cash need is an even more important motive for debt issues than for equity issues.

Cash needs can be defined using either actual revenue and spending (an ex post measure) or projected revenue and spending (an ex ante measure). While DDS (2010) focus on SEOs, Denis and McKeon (2012) document that immediate cash needs are the primary motive for 2,314 debt issues for which the resulting market leverage is substantially above the estimated target from 1971-1999. Both DDS and Denis and McKeon focus on ex post measures of cash needs, which could reflect a reverse-causality effect. Specifically, reverse-causality would be important if, when the cost of capital is low, firms raise capital and quickly spend the proceeds on projects 
that they would not otherwise take, using up the cash. Our paper examines both ex post and ex ante measures of cash needs. Our ex ante measures of cash needs are less subject to the reversecausality concern than our ex post measures. We find that although immediate cash needs that are measured ex ante are less predictive than ex post measures, they are still the most important predictor for debt issues and a highly important predictor for equity issues, alleviating the reverse-causality concern.

McLean and Palazzo (2017) also use an ex ante measure of cash needs, and find that cash squeezes are the primary trigger for debt issues that are not accompanied by debt repurchases, consistent with our finding on net debt issues. Their paper focuses on gross debt issues and disentangles motives for debt refinancing, whereas our paper studies net debt and equity issues.

Several theories have been proposed to explain securities issuance decisions. The pecking order theory posits that firms will issue only when they need to, and that they will raise external equity only when they have no alternative (Myers (1984)). The precautionary saving theory posits that firms facing more uncertainties are more likely to issue equity (Bates, Kahle, and Stulz (2009) and McLean (2011)). The static tradeoff theory emphasizes adjustment toward leverage targets. If there are economically important fixed costs of issuing, a dynamic tradeoff model can explain why some firms may delay issuing until running out of cash. The corporate lifecycle theory posits that young firms rely more on external equity than old firms (DDS), perhaps due to precautionary savings and static tradeoff motivations. The market timing theory posits that firms issue equity when the relative cost of equity is low and issue debt when the relative cost of debt is low. There are three versions of market timing. Unconditional timing theories view relative costs as important and economic fundamentals (e.g., funding needs as well as lifecycle, precautionary saving, and tradeoff motives) as unimportant or negligible for 
securities issuance decisions (Loughran and Ritter (1995) and Baker and Wurgler (2002)). In contrast, conditional timing theories recognize the importance of both relative costs and fundamentals (Huang and Ritter (2009)). Reverse-causality timing theories emphasize causality that runs from timing opportunities to investment decisions (Baker, Stein, and Wurgler (2003)).

Our paper makes several contributions to the securities issuance literature. First, we evaluate the relative economic significance of funding- and non-funding-related factors in explaining debt and equity issue decisions. ${ }^{2}$ We also explicitly distinguish among immediate (year $\mathrm{t}$ ), near-future (year $\mathrm{t}+1$ ), and remote-future (year $\mathrm{t}+2$ ) funding needs. Many theories of capital structure help explain firm financing patterns. The pecking order model with adverse selection costs, dynamic tradeoff models with issuing costs, and market timing models with reverse causality can explain why firms wait until they are running out of cash to raise external capital. Firms, however, also issue debt and equity for other purposes, such as leverage adjustments, market timing, and precautionary savings, even when they do not have immediate funding needs. Therefore, it is important to evaluate the relative economic significance of the funding- and non-funding-related factors suggested by various theories.

Second, we examine several alternative measures of cash squeezes to alleviate the endogeneity or reverse-causality concern that the explanatory power of ex post cash needs is largely due to the tendency to spend more money because more money has been raised.

Third, we test both, rather than just one, of the predictions of the pecking order theory. The pecking order theory predicts that firms will issue only when they need to, and that when they issue, debt will be used unless they have no choice. While existing papers (e.g., Fama and

\footnotetext{
${ }^{2}$ Neither Hovakimian (2004) nor Huang and Ritter (2009) emphasize the importance of cash needs in their analysis of the security issuance decision. DDS (2010) do not include a cash shortfall measure as an independent variable in their logit regressions for SEOs. Denis and McKeon (2012) focus on debt issues but do not examine the decision to issue debt.
} 
French $(2002,2005)$ and Huang and Ritter (2009)) document that many firms that could issue debt instead issue equity, we document that $32.9 \%$ of issuers would not have run out of cash, and thus are not predicted by the pecking order theory. We document that $41.3 \%$ of equity issuers have no choice, because they are running out of cash but already have high leverage or negative operating cash flow (or both). These results are generally consistent with those of Fama and French (2005, Table 5), although their sample of equity issues includes many small equity issues and they do not explicitly examine cash depletion.

Fourth, we relate cash changes associated with securities issues to funding- and nonfunding-related proxies. We find that debt issuers spend almost of all of the issuing proceeds in the same year. In contrast, equity issuers save a large fraction of the proceeds for future uses, especially when equity valuation is high.

Finally, we do a comprehensive evaluation of the importance of proxies for corporate lifecycle, pecking order, precautionary saving, timing, and tradeoff motives in explaining the debt vs. equity choice, conditional on issuing a security and running out of cash. ${ }^{3}$

In this paper, we define securities issues by U.S. firms from 1972-2010 using information from cash flow statements. A firm is defined as a debt issuer or an equity issuer if net debt or net equity proceeds in a year are at least $5 \%$ of the book value of assets and $3 \%$ of the market value of equity at the beginning of the year. In our definition, equity issuers include firms receiving cash from SEOs (also known as follow-ons), private investment in public equity (PIPEs) transactions, large employee stock option exercises, and preferred stock issues. ${ }^{4}$ Our sample

\footnotetext{
${ }^{3}$ In contrast, Kim and Weisbach (2008), DDS (2010), and McLean (2011) focus exclusively on equity issues, while Denis and McKeon (2012) focus exclusively on debt issues associated with large leverage increases. Lewis and Tan (2015) focus on the ability of the debt vs. equity choice to predict future stock returns, but do not address motives for financing decisions other than market timing.

${ }^{4}$ Since we require a one-year stock return prior to the current fiscal year, initial public offerings (IPOs) and SEOs shortly after the IPO are not included in our sample. Because cash flow statements are used, stock-financed acquisitions are not counted as equity issues.
} 
includes 12,442 equity issues. Debt issuers in our sample include firms receiving cash from straight and convertible bond offerings and increases in bank loans. Our sample includes 24,859 debt issues, almost 11 times as many as in the sample of Denis and McKeon (2012).

We identify firms that are running out of cash by the end of year $t$ using hypothetical cash balances. Cash ex post, an ex post measure, denotes what the cash balance at the end of $\mathrm{t}$ would have been if actual revenue and spending occurred and there was no external financing. Cash $\mathrm{ex}_{\mathrm{x}}$ post is equal to $\mathrm{Cash}_{\mathrm{t}-1}+\mathrm{NCF}_{\mathrm{t}}$, where $\mathrm{Cash}_{\mathrm{t}-1}$ denotes the amount of cash at the end of year $\mathrm{t}-1$, and $\mathrm{NCF}_{\mathrm{t}}$ denotes the net cash flow in $\mathrm{t}$. Using Cash ex post, $76.1 \%$ of debt issuers would have run out of cash and $90.3 \%$ of them would have had a subnormal cash ratio at the end of the year. If the equity issuers in our sample did not raise external capital, 54.4\% of them would have run out of cash and $79.0 \%$ of them would have had a subnormal cash ratio at the end of the year. Our findings on the likelihood of cash depletion using Cash ex post for equity issuers are generally consistent with those of DDS.

When using Cash ex post to predict financing decisions in year $\mathrm{t}$, we assume that $\mathrm{NCF}_{\mathrm{t}}$ is exogenous. However, ex post measures are subject to the endogeneity concern that a firm is likely to spend more if it raises external capital than if it didn't. To avoid this concern, we use several alternative measures of cash depletion, which continue to be the most important predictors of debt issues and important predictors of equity issues. Using Cash ex ante, defined as $\mathrm{Cash}_{\mathrm{t}-1}+\mathrm{NCF}_{\mathrm{t}-1}$, which assumes that the net cash flow in year $\mathrm{t}$ will be the same as in year $\mathrm{t}-1$, $43.1 \%$ of debt issuers and $44.8 \%$ of equity issuers would have run out of cash at the end of year $t$ if they had not issued.

Rather than looking at the likelihood of running out of cash for firms that issue, we can instead examine the security issuance of firms that are running out of cash. We estimate 
multinomial logit regressions to evaluate the economic significance of various determinants for the decision to issue debt, equity, both debt and equity, or no security. Using Cash ex post, immediate cash squeezes are the primary trigger for both debt and equity issuances. Firms that are running out of cash at the end of year $t$ are 11 times more likely to issue debt in year $t$ than firms that are not (69.8\% vs. $6.3 \%)$ after controlling for other variables. The likelihoods of equity issuance by firms that are running out of cash in year $t$ and firms that are not differ by a factor of four, at $24.5 \%$ and $6.1 \%$, respectively. Using an ex post measure, near-future cash needs are also important, but less important than immediate cash needs in predicting securities issuance.

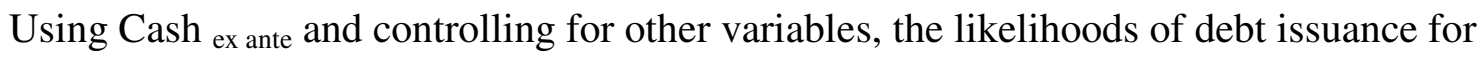
firms that are running out of cash and firms that are not differ by a factor of two, at $30.8 \%$ vs. $17.4 \%$, respectively, and their likelihoods of equity issuance also differ by a factor of two, at $16.0 \%$ vs. $8.5 \%$, respectively. Reverse-causality timing theories could explain the importance of our ex post measures of cash depletion, but they do not explain why our ex ante measures of cash depletion are important in predicting the decision to issue debt or equity.

When there is an immediate cash need, firms must choose between debt and equity if they seek external financing. Conditional on issuing a security, the most important predictors of the debt vs. equity choice are lagged measures of internal cash flow, firm size, the default spread, and Tobin's Q. A two standard deviation increase in the four variables is associated with a change in the likelihood of an equity issue of $-12.5 \%,-9.3 \%, 8.6 \%$, and $8.4 \%$, respectively. Thus, both fundamentals and timing proxies are important, consistent with conditional market timing. The results are similar when using a subsample of issuers that are running out of cash.

We also relate debt and equity issues to changes in cash, and examine how these relations depend on cash needs and non-funding-related motives. As mentioned in our first paragraph, on 
average, net debt issuers immediately spend 85.9 cents of an incremental dollar in their issuing proceeds, and save only 14.1 cents in cash, whereas net equity issuers with at least \$200 million in assets immediately spend only 59.4 cents of an incremental dollar in their issuing proceeds, and save 40.6 cents in cash. The fact that equity issuers save a large fraction of the proceeds in cash has been interpreted as supportive of market timing theories (Kim and Weisbach (2008)). We caution that timing is not responsible for all of the high savings rate. As Fama and French (2005) and DDS (2010) also note, many equity issuers are small and unprofitable and experience substantial growth in non-cash assets, thus it is reasonable for them to increase cash balances and prepare for future cash needs. We present evidence that both fundamentals and market timing proxies can explain much of the savings.

To summarize, we show that accounting information about whether a firm has a cash squeeze is the most important predictor of external financing activity. This finding is consistent with the pecking order theory, with dynamic tradeoff models for firms with large fixed adjustment costs, and with reverse-causality timing models, but indicates a limit on theories that focus on adjusting leverage, stockpiling cash, or precautionary savings being the primary motive for issuing securities. ${ }^{5}$ As has been documented by previous research, however, the pecking order theory does a poor job at predicting which issuers will choose equity financing. Valuation information is an important predictor of the debt vs. equity choice, consistent with conditional market timing. Precautionary savings, life cycle, and static tradeoff theories also all have a role to play.

\footnotetext{
${ }^{5}$ This finding is consistent with the pecking order theory developed on the basis of information asymmetry. A dynamic tradeoff theory with leverage adjustment costs can also explain this finding, although the sources of the costs are not easy to determine and can also be related to information asymmetry. Underwriters, lenders, and investors incur both fixed costs and variable costs when they acquire and analyze information about issuers and borrowers, and such costs can be larger when information asymmetry is higher.
} 


\section{Data, variables, summary statistics, and univariate sorts}

\subsection{Data and variables}

We use Compustat to obtain financial statement information and CRSP to obtain stock prices for each U.S. firm. We require the statement of cash flow information for fiscal years $t$ and t-1. Since the cash flow information is only available from 1971, our final sample starts from 1972. ${ }^{6}$ Since we also examine stock returns in the three years after each financing decision, our sample period ends at 2010. We also drop firm-year observations for which frequently used variables in our paper have a missing value, the net sales is not positive, the book value of assets at the end of fiscal year $\mathrm{t}-1$ or $\mathrm{t}$ is less than $\$ 10$ million (expressed in terms of purchasing power at the end of 2010), the book value of assets at the end of year t-2 is missing, the cash flow identity is violated in $\mathrm{t}$ and $\mathrm{t}-1$, or there is a major merger in $\mathrm{t}^{7}{ }^{7}$ To avoid the effect of regulations on financing choices, we remove financial and utility firms from our analysis. Our final sample includes 116,488 firm-year observations from 1972-2010.

As market timing proxies, we use Tobin's Q, the stock return in year t-1, the stock return from $t+1$ to $t+3$, the term spread, and the default spread. As lifecycle proxies, while DDS use only firm age, we favor the corporate lifecycle theory by using both firm size (the logarithm of net sales) and age. As precautionary saving proxies, following McLean (2011), we use R\&D expense, industry cash flow volatility, and a dividend payer dummy variable. For the tradeoff theory, we use lagged leverage as a proxy. Detailed definitions of the variables used in this paper are provided in the Appendix. We use statements of cash flow information, so equity issued for

\footnotetext{
${ }^{6}$ We use the number of years that a firm has been listed on CRSP as a measure for the firm's age. CRSP first included NASDAQ stocks in December 1972. As DDS point out, the number of years on CRSP is not a reliable measure for firm age for these firms. Our major results are essentially the same if we add five years to the age of these firms or simply exclude these firms from our sample.

${ }^{7} \mathrm{~A}$ violation of the cash flow identity in year $\mathrm{t}$ is identified as where the absolute value of $\left(\Delta \mathrm{D}_{\mathrm{t}}+\Delta \mathrm{E}_{\mathrm{t}}+\mathrm{ICF}_{\mathrm{t}}-\right.$ Investments $_{\mathrm{t}}-\Delta \mathrm{NWC}_{\mathrm{t}}-\mathrm{Cash}_{\text {Dividends }}$ ) $\div$ Assets $_{\mathrm{t}-1}>0.005$ (see the Appendix for detailed variable definitions). A major merger is identified by the Compustat footnote for net sales being AB, FD, FE, or FF. Our data requirements result in the dropping of firms that solved their cash shortfall problems by being acquired during year $t$.
} 
stock-financed acquisitions is not counted as an equity issue. To minimize the influence of outliers, all non-categorical variables except for the stock returns are winsorized at the $0.5 \%$ level at each tail of our sample.

\subsection{Summary statistics and univariate sorts}

Figure 1A reports the likelihood of cash depletion on the basis of $\mathrm{Cash}_{\mathrm{ex}}$ post, defined as Cash $_{\mathrm{t}-1}+\mathrm{NCF}_{\mathrm{t}} . \mathrm{NCF}_{\mathrm{t}}$ equals $\mathrm{ICF}_{\mathrm{t}}-$ Investments $_{\mathrm{t}}-\Delta$ Non-Cash $\mathrm{NWC}_{\mathrm{t}}-$ Cash Dividends $_{\mathrm{t}}$, where $\mathrm{ICF}_{\mathrm{t}}$ is the internal cash flow, and $\triangle \mathrm{Non}-\mathrm{Cash} \mathrm{NWC}_{\mathrm{t}}$ is the change in non-cash net working capital (see the Appendix for details). Due to the sources = uses of funds identity, $\mathrm{Cash}_{\text {ex post }}$ also equals Cash $\mathrm{C}_{t}-\Delta \mathrm{D}_{\mathrm{t}}-\Delta \mathrm{E}_{\mathrm{t}}$, where $\Delta \mathrm{D}_{\mathrm{t}}$ is the net debt issue in $\mathrm{t}$, and $\Delta \mathrm{E}_{\mathrm{t}}$ is the net equity issue in $\mathrm{t}^{8}$ Inspection of the figure shows that larger issue sizes are associated with a higher probability of running out of cash, with this relation being much stronger for debt issues than equity issues. The finding that firms that raise more capital often have larger cash needs undercuts the importance of active leverage adjustment, precautionary saving, and unconditional market timing motives.

Figure 1B shows the likelihood of cash depletion on the basis of $\mathrm{Cash}_{\mathrm{ex}}$ ante, defined as $\mathrm{Cash}_{\mathrm{t}-1}+\mathrm{NCF}_{\mathrm{t}-1}$. Cash $\mathrm{ex}$ ante only uses information prior to year $\mathrm{t}$. It uses the realized $\mathrm{NCF}_{\mathrm{t}-1}$ as the expected $\mathrm{NCF}_{\mathrm{t}}$. There is still a positive relation between issue size and the likelihood of cash depletion in Figure 1B, although the relation is weaker than in Figure 1A. For firms with an issue size greater than $5 \%$ of beginning-of-year assets, the cash depletion likelihoods on the basis of

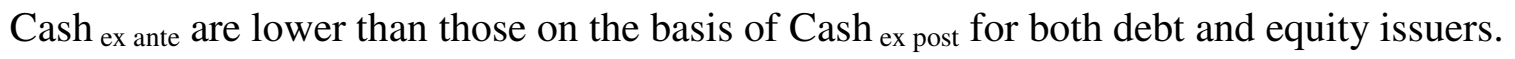

Table 1 reports the sample distribution by security issue activities. If firms actively target a desired capital structure, firms with cash shortfalls could issue both debt and equity to stay

\footnotetext{
${ }^{8}$ Our cash need measures are different from the financing deficit that many papers focus on (e.g., Frank and Goyal (2003)). As DDS point out, a firm with a large financing deficit and a high cash balance does not necessarily have an immediate need to raise external capital.
} 
close to their target leverage (Hovakimian, Hovakimian, and Tehranian (2004)). Therefore, we distinguish among pure debt issues, pure equity issues, and dual issues of both debt and equity.

Panel A of Table 1 reports the distribution by the issuance and choice of securities.

Issuance years are defined as years in which either the net debt or net equity proceeds on the cash flow statement is at least $5 \%$ of book assets and $3 \%$ of market equity at the beginning of the year. There is no security issue, using this definition, in $70.7 \%$ of firm-years. Debt issues occur more often than equity issues. A pure debt issue, a pure equity issue, and dual issues of debt and equity occur in $18.7 \%, 8.0 \%$, and $2.7 \%$ of firm-years, respectively. One argument against the market timing theory is that many firms with good equity market timing opportunities do not issue equity. In our sample, an equity issue occurs in $10.7 \%$ of the firm-years. ${ }^{9}$ In comparison, DDS document that the probability of an SEO in a given year is $3.4 \% .{ }^{10}$ Conditional on issuing, the likelihoods of debt and equity issues are $72.7 \%$ and $36.4 \%$, respectively.

Panel B of Table 1 reports the distribution by cash depletion (using either Cash ex post or Cash $_{\text {ex ante }}$ ) and issuing a security or not. Firms are running out of cash at the end of $t$ on the basis of Cash ex post in $24.3 \%$ of the years and on the basis of Cash ex ante in $28.5 \%$ of the years. For firms that do not issue a security, the likelihood of cash depletion is $6.5 \%$ on the basis of

\footnotetext{
${ }^{9}$ Fama and French (2005) document that although SEOs are not common, on average 54\% of their sample firmyears make net equity issues during 1973-1982, and the proportion increases to $62 \%$ for $1983-1992$ and $72 \%$ for 1993-2002. Our equity issue probabilities are lower than those reported in Fama and French, who do not impose a minimum requirement of 5\% of assets and 3\% of market equity, and who include share issues that do not generate cash, such as stock-financed acquisitions and contributions to employee stock ownership plans (ESOPs). Although exercises of employee stock options generate cash for the company, they are passive, rather than active, actions by the issuing firm, and they occur following stock price increases, although not necessarily after an increase in t- 1 . McKeon (2015) reports that a 3\% of market equity screen removes from the equity issuance category almost all firm-years with only stock option exercises.

${ }^{10}$ To understand why our frequency of equity issues is so much higher than the DDS frequency, we investigated 50 random equity issuers using the Thomson Reuters' SDC database, Sagient Research's Placement Tracker database, and annual reports on the S.E.C.'s EDGAR web site. We found that PIPEs were almost as frequent as SEOs, and that SDC missed some SEOs. PIPEs are more common among smaller issuers, so our sample of equity issuers is tilted towards smaller firms relative to the DDS issuers. Gustafson and Iliev (2017) document that PIPEs have become less common following a 2008 S.E.C. regulatory change allowing small reporting companies (those with a public float of less than $\$ 75$ million) to conduct shelf registrations.
} 


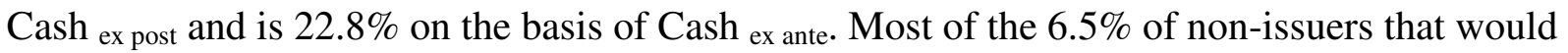
run out of cash actually did some external financing, but not enough to meet our 5\% thresholds. For security issuers, the likelihood of cash depletion is $67.1 \%$ on the basis of Cash ex post and is $42.4 \%$ on the basis of Cash ex ante. These results suggest that security issuers are much more likely to run out of cash at the end of $t$ than non-issuers, even when Cash $\mathrm{ex}_{\text {ante }}$ is used.

Panel $\mathrm{C}$ of Table 1 reports the distribution by cash depletion and security choice. The likelihoods of cash depletion using Cash ex post are $74.4 \%$ and $43.1 \%$ for pure debt issuers and pure equity issuers, respectively.

Panel D of Table 1 reports the probability of issuing securities, conditional on either running out of cash or not. As mentioned in the introduction, $81.1 \%$ of firms that are running out of cash on the basis of Cash ex post conduct a significant issue of debt or equity, but only $12.7 \%$ of other firms do so. When Cash ex ante is used, the probabilities are $43.6 \%$ and $23.7 \%$, respectively. These results suggest that a cash squeeze is a very important motive for external financing. Using an ex ante measure of cash needs, McLean and Palazzo (2017) find that about half of cash squeezed firms issue debt or equity, consistent with our results.

Panel $\mathrm{E}$ of Table 1 shows that, among firms that do significant external financing in the presence of a cash squeeze, $82.5 \%$ of firms issue debt and $29.5 \%$ issue equity, with $12.0 \%$ of these firms issuing both.

Figure 2 shows for each fiscal year during 1972-2010 the fraction of debt or equity issuers that have an equity issue and the average Tobin's $Q$ at the end of the year. The fraction varies substantially between 5\% in 1974 (when equity valuations were low) and 65\% in 2009 (when credit spreads were high). To understand whether time-varying growth opportunities and costs of equity help explain the variation in the debt vs. equity choice across time, we plot the 
average Tobin's Q of our sample firms in the same figure. The large variation over time in the choice of debt vs. equity combined with the strong positive correlation $(\rho=0.74)$ between the equity issuance fraction and Tobin's Q suggests that market timing is quantitatively important.

Panel A of Table 2 reports the means and medians for the cash flow components sorted by security issues. On average, pure equity issuers and dual issuers have the lowest $\mathrm{ICF}_{\mathrm{t}}$ $\div$ Assets $_{\mathrm{t}-1}$, suggesting that many are unable to borrow because of a lack of profitability. Dual issuers have the largest Investment $\mathrm{t}_{\mathrm{t}} \div$ Assets $_{\mathrm{t}-1}$, followed by pure debt issuers and pure equity issuers. The mean of Cash Dividends $\mathrm{s}_{\mathrm{t}} \div$ Assets $_{\mathrm{t}-1}$ is no greater than $1.2 \%$ for all four categories of firms, suggesting that dividend cuts and omissions play a limited role in meeting large short-term cash needs. The overall mean of $1.1 \%$ is low because we are equally weighting firms, and most small firms pay no dividends. The mean $\Delta \mathrm{NWC}_{\mathrm{t}} \div \mathrm{Assets}_{\mathrm{t}-1}$ varies from $0.3 \%$ for firms that issue no security to $17.9 \%$ for dual issuers. ${ }^{11}$

Panel B of Table 2 reports statistics on the cash change as a percent of the net equity issue amount for equity issuers and as a percent of the net debt issue amount for debt issuers. On average, net equity issuers increase cash by $31.5 \%$ of the net equity issue proceeds, and net debt issuers increase cash by only $5.9 \%$ of the net debt issue proceeds.

Table 3 reports the summary statistics for cash, excess cash, and hypothetical likelihoods of cash depletion. To control for the effects of industry, growth opportunities, and firm size, we compute the excess cash ratios as the difference between the cash ratio of the firm and the median cash ratio in the same year of firms in the same industry, the same tercile of Tobin's Q,

\footnotetext{
${ }^{11}$ Our Figure 1 shows that firms that have a larger issue are more likely to run out of cash if they did not issue. To further understand this finding, Internet Appendix Table IA-1 reports the means and medians of the cash flow components for firms sorted by net equity issue size and net debt issue size, respectively, as a percent of beginningof-year assets. Not surprisingly, firms with a larger equity issues generally invest more and have lower profitability. Interestingly, this group of firms not only has the largest cash need, but also has the largest increase in cash holdings in the same year.
} 
and the same tercile of total assets. Panel A reports the means and medians of cash and excess cash at the end of each year from $t-1$ to $t+1$, all expressed as a percent of assets. Pure equity issuers have much higher cash ratios in the year before, the year of, and the year after the issue than the other categories of firms, suggesting a stockpiling effect, consistent with the precautionary saving theory. A higher cash ratio can be optimal for small growth firms, as noted by DDS. For example, a money-losing biotech company will find it easier to attract and retain employees if it has cash on the balance sheet.

To measure the likelihood of cash depletion of an SEO firm, DDS initially focus on an ex post measure of the issuer's pro forma cash balance at the end of the subsequent fiscal year $(\mathrm{t}+1)$ after the SEO year ( $t$ ), assuming zero SEO proceeds in year $t$ and that the firm's actual operating, investing, and other financing activities in $t$ and $t+1$ would be the same whether or not the firm had the SEO in year t. To alleviate potential reverse-causality concerns, they do robustness tests by assuming no capital expenditure increases in $t$ and $t+1$, no increases in debt in $t$ and $t+1$, or no dividends in $t$ and $t+1$, and still find that many SEO issuers would have run out of cash.

Following DDS, we present the likelihoods of cash depletion in Panel B, both unconditionally (the "All” column) and conditional on actual security issuance, under a variety of assumptions. In row (1), the probabilities of an ex post cash squeeze $\left(\right.$ Cash ex post $=\operatorname{Cash}_{t}-\Delta D_{t}$ $\left.-\Delta \mathrm{E}_{\mathrm{t}}<0\right)$ at the end of $\mathrm{t}$ are $76.1 \%$ for debt issuers and $54.4 \%$ for equity issuers, suggesting that debt issuers are much more likely to have immediate cash needs than are equity issuers. ${ }^{12}$

In rows (2)-(4), we use three alternative assumptions for the expected $\mathrm{NCF}_{\mathrm{t}}$ that do not use actual spending, to alleviate a reverse-causality concern associated with Cash ex post. Using Cash ex ante $\left(\mathrm{Cash}_{\mathrm{t}-1}+\mathrm{NCF}_{\mathrm{t}-1}\right)$, the likelihoods of cash depletion at $\mathrm{t}$ if they didn't issue are much

\footnotetext{
${ }^{12}$ Denis and McKeon (2012) document that for 2,314 firm years with large leverage increases between 1971-1999, the likelihood of cash depletion is between $70.8 \%$ and $93.4 \%$.
} 
lower at $43.1 \%$ and $44.8 \%$, respectively, for the firms that actually did issue debt or equity.

$\mathrm{NCF}_{\mathrm{t}-1}$ is not, however, an ideal measure of next year's net cash flow. Managers have more information about cash needs in $\mathrm{t}$ than $\mathrm{NCF}_{\mathrm{t}-1}$, and mean reversion in the net cash flow is also possible. To alleviate these concerns, our second alternative measure is $\operatorname{Cash}_{\mathrm{t}-1}+\operatorname{Median} \mathrm{NCF}_{\mathrm{t}}$, where Median $\mathrm{NCF}_{\mathrm{t}}=$ Assets $_{\mathrm{t}-1}$ of the firm $\times$ the median of $\mathrm{NCF}_{\mathrm{t}} \div$ Assets $_{\mathrm{t}-1}$ of firms in the same industry, the same tercile of Tobin's Q, and the same tercile of assets. Using this measure, the likelihoods of cash depletion at $\mathrm{t}$ for the firms that actually did issue debt or equity in row (3) are $35.5 \%$ and $29.2 \%$, respectively, if they had not issued. We also estimate regressions, reported in Internet Appendix Table IA-2, using a list of ex ante variables to predict $\mathrm{NCF}_{\mathrm{t}} \div \mathrm{Assets}_{\mathrm{t}-1}$, and then use $\mathrm{Cash}_{\mathrm{t}-1}+$ Assets $_{\mathrm{t}-1} \times$ the fitted value of $\mathrm{NCF}_{\mathrm{t}} \div$ Assets $_{\mathrm{t}-1}$ to identify cash depletion in $\mathrm{t}$. Using this third alternative measure, the likelihoods of cash depletion at $t$ for debt and equity issuers in row (4) are $35.8 \%$ and $38.9 \%$, respectively. The likelihoods of cash depletion are much lower using these three counterfactuals than using the actual $\mathrm{NCF}_{\mathrm{t}}$.

The next six rows [rows (5)-(10)] present the probabilities of having a cash squeeze if alternative financing policies were implemented in year t. For example, row (7) asks what the likelihoods are if an issuer still issues but cuts the issue size by half. Using $\operatorname{Cash}_{t}-0.5 \times\left(\Delta D_{t}\right.$ $+\Delta \mathrm{E}_{\mathrm{t}}$ ), the likelihoods of cash depletion at $\mathrm{t}$ for a debt and an equity issuer are $58.4 \%$ and $34.7 \%$, respectively. ${ }^{13}$ These findings suggest that many issuers could have cut their net issue size by half without running out of cash in the immediate future.

Rows (8) and (9) address how important dividends and increases in interest payments are for the probability of a firm running into a cash squeeze. Inspection of the rows shows that the

\footnotetext{
${ }^{13}$ A careful reader might note that in row (7) the probability of running out of cash is $3.6 \%$ for firms that did not issue, which is not the same as the $6.5 \%$ probability in row (1). These numbers are not identical because not all of the nonissuing firms had $\Delta \mathrm{D}_{\mathrm{t}}=\Delta \mathrm{E}_{\mathrm{t}}=0$. Many had an issue of less than $5 \%$, and some had an issue of more than $5 \%$ of assets but less than $3 \%$ of the market value of equity at the beginning of the year.
} 
likelihoods are similar to those in row (1) using $\operatorname{Cash}_{t}-\Delta D_{t}-\Delta E_{t}$, suggesting that dividends and interest expense changes have no material effects on the likelihoods of cash depletion.

McLean (2011) assumes zero equity issuance instead of zero net equity issuance in computing the likelihood of cash depletion. Following his approach of using $\mathrm{Cash}_{t}-$ Gross Equity Issue $_{t}$, in row (10) the likelihood of cash depletion at the end of $t$ is $59.9 \%$ for equity issuers in our sample and a much smaller $10.6 \%$ for all firms in our sample, suggesting that firms with a significant net equity issue have a larger immediate cash need. McLean's equity issue sample includes all firm years with a positive equity issue amount on the cash flow statements, including small amounts from employee stock option exercise. Our untabulated results show that the likelihood of cash depletion in a year for our subsample of firms with a positive (rather than $5 \%$ ) equity issuance amount is $14.9 \%$, which is close to the $17 \%$ that McLean reports and the $15.6 \%$ that McKeon (2015) reports. ${ }^{14}$ When McLean defines equity issuers as firms in the top yearly issue tercile, with the terciles being made among firms with a positive issue amount, the likelihood of cash depletion is $44 \%$.

Even if a firm is not running out of cash, raising capital can be justified if its cash ratio is subnormal. DDS document that $81.1 \%$ of SEO firms would have had subnormal cash balances without the SEO proceeds. Following DDS, we compute the likelihoods of having a cash ratio below the median cash ratio of similar firms, defined as firms in the same year, the same industry, the same tercile of Tobin's Q, and the same tercile of assets. Using the ex post net cash flow, in row (11) the likelihoods of having a subnormal cash ratio at the end of $t$ with zero net external capital are $90.3 \%$ and $79.0 \%$ for debt and equity issuers, respectively. Using the ex ante net cash

\footnotetext{
${ }^{14}$ Note that the $14.9 \%$ likelihood is not directly comparable to the likelihoods in Figure 1A, which use net equity issuance. Firms frequently repurchase shares to reduce the dilutive effect of employee stock option exercises.
} 
flow, in row (12) the likelihoods are $68.1 \%$ and $69.1 \%$, respectively. If they cut the issue size by half, in row (13) the likelihoods are $84.1 \%$ and $66.5 \%$, respectively.

We also compute the likelihood of cash depletion at the end of either $t$ or $t+1$ (near-term) if a firm does not issue equity or debt in both $t$ and $t+1$. The likelihoods of near-term cash depletion in row (14) are $84.2 \%$ and $72.3 \%$ for debt and equity issuers, respectively. Using an ex ante measure, in row (15) the likelihoods become $52.0 \%$ and $58.2 \%$, respectively. The results using the ex ante measure are similar to those when the cash depletion measures are based on the median NCF ratio and the fitted-value NCF ratio.

DDS examine the likelihood of cash depletion at the end of $t+1$ for firms with an SEO in $\mathrm{t}$, assuming zero SEO proceeds in $\mathrm{t}$ and holding other cash uses and sources at their actual values. To make our results more comparable to theirs, in row (18) we compute the likelihood of $\mathrm{Cash}_{\mathrm{t}+1}$ $-\Delta \mathrm{E}_{\mathrm{t}} \leq 0$. For our sample of equity issuers, the likelihood of cash depletion at the end of $t+1$ is $60.0 \%$, which is close to their $62.6 \%$. However, it is possible that a firm is running out of cash at $t$ but will not run out of cash at $t+1$. Consistent with this possibility, in row (19) the likelihood of cash depletion at $\mathrm{t}$ or $\mathrm{t}+1\left(\mathrm{Cash}_{\mathrm{t}}-\Delta \mathrm{E}_{\mathrm{t}} \leq 0\right.$ or $\left.\operatorname{Cash}_{\mathrm{t}+1}-\Delta \mathrm{E}_{\mathrm{t}} \leq 0\right)$ is a higher $70.8 \%$.

Table 3 also reports the likelihoods of near-future cash depletion (running out of cash at the end of $t+1$ but not at the end of $t$ ) in rows (20-23), and the likelihoods of remote-future cash depletion (running out of cash at the end of $t+2$ but not at the end of $t$ or $t+1$ ) in rows (24-27). Generally, the likelihoods of near-future cash depletion are much lower than the likelihoods of immediate cash depletion and the likelihoods of remote-future cash depletion are even lower, regardless of whether ex post measures of cash needs or alternative measures are used.

Table 4 presents the means and medians for the control variables that are used in our regressions. For the full sample in Panel A, among the four subsets of firms, pure equity issuers 
have the highest Tobin's Q, consistent with earlier studies that show that firms with growth opportunities and a high stock valuation are more likely to issue equity. Pure equity issuers and dual issuers have the highest average prior-year stock returns of $44.8 \%$ and $46.7 \%$, respectively, and the lowest 3-year buy-and-hold stock returns of $14.9 \%$ and $10.5 \%$ from year $t+1$ to $t+3$, consistent with the market timing literature. The stock return from $t+1$ to $t+3$ is much higher for pure debt issuers than for equity issuers, consistent with Huang and Ritter (2017). Pure equity issuers and dual issuers are smaller and younger than other firms. Pure equity issuers also have lower lagged leverage than debt issuers. Pure equity issuers have the highest $R \& D$, and are in industries with the highest cash flow volatility and are the least likely to be a dividend payer in the prior year, consistent with prior studies. ${ }^{15}$

Cash needs are not incompatible with market timing motives because firms that are running out of cash can still choose between debt and equity. Panel B of Table 4 reports the mean and median characteristics for firms that are running out of cash and issuing a security. Firms that are running out of cash and issuing only equity have an average 3-year buy-and-hold stock return from $t+1$ to $t+3$ of only $2.8 \%$, suggesting that these firms are still able to time the market. It is difficult to justify this extremely low mean return as an equilibrium return, although the issuers that are running out of cash are tilted towards low profitability and heavy investment, characteristics associated with low returns in the asset pricing literature (Hou, Xue, and Zhang, 2015). These findings suggest that some firms successfully time the market to issue equity and quickly spend the proceeds. Even if the low returns can be accounted for in a multifactor model, the lack of a significantly negative alpha may be due to successful factor timing, e.g., with some

\footnotetext{
${ }^{15}$ Internet Appendix Table IA-3 reports the mean and median characteristics for young and old firms separately. Younger firms are generally smaller and have higher Tobin's Q than old firms. Young equity issuers have slightly lower future stock returns than old equity issuers.
} 
money-losing firms issuing before these issuers and other firms with similar characteristics underperform (Greenwood and Hanson (2012)).

Table 5 uses univariate sorts to evaluate the relations of our cash need measures and control variables with the propensities to issue securities. For each of the subgroups sorted by a variable, we compute the proportion of firm-years that fall into one of the four categories of security issue choices (or six categories when dual issuers are added to pure debt and pure equity issuers). Firms with more cash are less likely to issue debt, but are more likely to issue equity. Among the net cash flow measures for different years, $\mathrm{NCF}_{\mathrm{t}} \div$ Assets $_{\mathrm{t}-1}$ stands out in explaining the likelihood of a debt issue in year t. For firms in the variable's lowest and highest quartiles, the likelihoods of debt issues are $55.6 \%$ and $2.9 \%$, respectively, with the low NCF firms almost 20 times more likely to issue debt. $\mathrm{NCF}_{\mathrm{t}-1} \div$ Assets $\mathrm{t}_{\mathrm{t}-1}$ is far less important, and future ratios $\mathrm{NCF}_{\mathrm{t}+1} \div$ Assets $_{\mathrm{t}-1}$ and $\mathrm{NCF}_{\mathrm{t}+2} \div$ Assets $_{\mathrm{t}-1}$ have little ability for explaining debt issues. The net cash flow measures from $\mathrm{t}-1$ to $\mathrm{t}+2$ are important in explaining an equity issue in $\mathrm{t}$. For firms in the first and fourth $\mathrm{NCF}_{\mathrm{t}} \div$ Assets $_{\mathrm{t}-1}$ quartiles, the probabilities of equity issues are $27.3 \%$ and $4.8 \%$, respectively, a difference of $22.5 \%$. For firms in the lowest and highest quartiles of $\mathrm{NCF}_{\mathrm{t}-1}$, $\mathrm{NCF}_{\mathrm{t}+1}, \mathrm{NCF}_{\mathrm{t}+2}$, all scaled by Assets $\mathrm{t}_{-1}$, the probabilities of equity issues differ by $16.2 \%, 16.8 \%$, and $13.3 \%$, respectively. These findings suggest that debt is issued almost exclusively for immediate cash needs, while equity issuers have large funding needs not only in the issuance year, but also before and after the issuance year.

Cash $_{\text {ex post }} \div$ Assets $_{\mathrm{t}-1}$ is the predominant predictor for debt issues. For firms in this variable's first and fourth quartiles, the likelihoods of a debt issue are $63.9 \%$ and $3.9 \%$, respectively. Cash ex post $\div$ Assets $_{\mathrm{t}-1}$ is also important for equity issues, but much less important 
than for debt issues. Cash ex ante $\div$ Assets $_{\mathrm{t}-1}$ is less important than Cash $_{\text {ex post }} \div$ Assets $_{\mathrm{t}-1}$, but still highly important for predicting debt and equity issues.

Inspection of Table 5 shows that firms with low internal cash flow, whether $\mathrm{ICF}_{\mathrm{t}-1}$ $\div$ Assets $_{\mathrm{t}-2}$ or $\mathrm{OIBD}_{\mathrm{t}-1}$, are frequent equity issuers, and firms with high investment are frequent issuers of both debt and equity. Tobin's Q is also an important predictor for equity issues. For firms in the first and fourth quartiles of Tobin's Q, the likelihoods of an equity issue in a given year are $4.3 \%$ and $19.5 \%$, respectively, a pattern qualitatively similar to that reported in Table 2 of DDS. In contrast, Tobin's Q is not strongly related to the likelihood of a debt issue. These results are consistent with Figure 2 . The stock return in year t-1 is positively related to the likelihood of both debt and equity issues. Unlike most of the sorts, the relation between lagged equity returns and equity issuance is non-monotonic, with small, unprofitable firms with negative prior returns frequently resorting to PIPEs. The stock return from $t+1$ to $t+3$ is more related to the likelihood of an equity issue than of a debt issue. For a firm in the lowest quartile of future stock returns, the likelihood of an equity issue is $18.7 \%$, suggesting that a significant proportion of firms with poor future stock performance are able to successfully time the market.

Table 5 shows that the term spread and the default spread are not important in predicting debt or equity issues, although we will show in Table 9's multinomial logit regressions that a higher default spread does discourage debt issuance. Larger and older firms are less likely to issue equity, consistent with the corporate lifecycle theory. Firms in the lowest leverage quartile are the least likely to issue debt, consistent with the findings of Strebulaev and Yang (2013). Consistent with the precautionary saving theory, higher R\&D firms, firms in an industry with higher cash flow volatility, and firms that do not pay dividends are more likely to issue equity. 
In Table 6, we classify firm-years on the basis of whether a firm is overleveraged relative to the median leverage of the firms in its industry and whether it has positive operating income before depreciation (OIBD) in year $\mathrm{t}-1$. Thus, firm-years are placed into one of four panels based on this $2 \times 2$ sort of profitability and leverage. Of equity issuers that are running out of cash, those with negative $\mathrm{OIBD}_{\mathrm{t}-1}$, and those with positive $\mathrm{OIBD}_{\mathrm{t}-1}$ but leverage that is already above the industry median, are considered to have no choice. ${ }^{16}$ Inspection of the table shows that 5,137 out of $12,427(41.3 \%)$ equity issuers have no choice, in that they have Cash ex post $\leqslant 0$ but do not have positive $\operatorname{OIBD}_{\mathrm{t}-1}$ and below median leverage. The other $58.7 \%$ of equity issuers presumably have a choice, and thus appear to violate the pecking order prediction. The 7,290 $(12,427-5,137)$ firm-years that violate the pecking order are only $6.3 \%$ of the 116,326 firm-years, considerably less than the $20.8 \%$ to $31.0 \%$ of firm-years in different subperiods that Fama and French (2005, Table 5) identify as violating the pecking order. The difference in results is primarily due to their inclusion of small equity issuers, many of which involve employee stock option exercise, in their counts. Table 6 also shows that $76.1 \%$ of debt issuers are consistent with the pecking order.

\section{Regression results}

\subsection{The decision to issue a security and the choice between debt and equity}

Our summary statistics and univariate sorts suggest that it is important to estimate the marginal effects of our immediate and future cash need measures and other variables on security issue decisions. Table 7 reports the multinomial logit results for the decision to issue a security in year $t$ and the choice between debt and equity. The base category consists of firms that have no security issue. Panel A reports the coefficients and z-statistics, and Panel B reports the economic

\footnotetext{
${ }^{16}$ Internet Appendix Table IA-4 reports the results using an ex ante measure of cash depletion.
} 
effects. Because the multinomial logit model is nonlinear, we focus our discussions on the economic effects.

In regression (1), cash depletion is defined using beginning cash balances and ex post net cash flows. Current Depletion Dummy, our measure for immediate cash depletion, equals one if $\mathrm{Cash}_{\mathrm{t}-1}+\mathrm{NCF}_{\mathrm{t}} \leqslant 0$ and zero otherwise. Near Depletion Dummy, a near-future cash depletion measure, equals one if $\mathrm{Cash}_{\mathrm{t}-1}+\mathrm{NCF}_{\mathrm{t}}>0$ and $\mathrm{Cash}_{\mathrm{t}-1}+\mathrm{NCF}_{\mathrm{t}}+\mathrm{NCF}_{\mathrm{t}+1} \leqslant 0$, and equals zero otherwise. Remote Depletion Dummy, a remote-future cash depletion measure, equals one if $\mathrm{Cash}_{\mathrm{t}-1}+\mathrm{NCF}_{\mathrm{t}}>0, \mathrm{Cash}_{\mathrm{t}-1}+\mathrm{NCF}_{\mathrm{t}}+\mathrm{NCF}_{\mathrm{t}+1}>0$, and $\mathrm{Cash}_{\mathrm{t}-1}+\mathrm{NCF}_{\mathrm{t}}+\mathrm{NCF}_{\mathrm{t}+1}+\mathrm{NCF}_{\mathrm{t}+2} \leqslant 0$, and equals zero otherwise. ${ }^{17}$ Panel B of Table 7 shows that Current Depletion Dummy is a prominent predictor for debt and equity issues. Firms that are running out of cash at the end of $\mathrm{t}$ are $63.5 \%$ more likely to issue debt in the same year than firms that are not running out of cash $(69.8 \%$ vs. $6.3 \%) .{ }^{18}$ Near Depletion Dummy is also highly important but much less important than Current Depletion Dummy. Firms that will run out of cash at $t+1$ are $11.2 \%$ more likely to issue debt than firms that will not run out of cash at $\mathrm{t}+1$ (31.2\% vs. $20.0 \%)$. For equity issues, both Current Depletion Dummy and Near Depletion Dummy are highly important predictors. Firms that are running out of cash in a fiscal year are $18.4 \%$ more likely to issue equity in the same year than firms that are not running out of cash $(24.5 \%$ vs. $6.1 \%)$. Firms that will run out of cash at $\mathrm{t}+1$ are $10.6 \%$ more likely to issue equity than firms that will not (19.9\% vs. $9.3 \%)$. Remote Depletion Dummy also has some predictive power for both debt and equity issuances.

\footnotetext{
${ }^{17}$ Note that by definition, $\operatorname{Cash}_{\mathrm{t}-1}+\mathrm{NCF}_{\mathrm{t}}=\mathrm{Cash}_{\mathrm{t}+1}-\Delta \mathrm{D}_{\mathrm{t}}-\Delta \mathrm{E}_{\mathrm{t}}, \mathrm{Cash}_{\mathrm{t}-1}+\mathrm{NCF}_{\mathrm{t}}+\mathrm{NCF}_{\mathrm{t}+1}=\mathrm{Cash}_{\mathrm{t}+1}-\Delta \mathrm{D}_{\mathrm{t}}-\Delta \mathrm{E}_{\mathrm{t}}-\Delta \mathrm{D}_{\mathrm{t}+1}-$ $\Delta \mathrm{E}_{\mathrm{t}+1}$, and $\mathrm{Cash}_{\mathrm{t}-1}+\mathrm{NCF}_{\mathrm{t}}+\mathrm{NCF}_{\mathrm{t}+1}+\mathrm{NCF}_{\mathrm{t}+2}=\mathrm{Cash}_{\mathrm{t}+2}-\Delta \mathrm{D}_{\mathrm{t}}-\Delta \mathrm{E}_{\mathrm{t}}-\Delta \mathrm{D}_{\mathrm{t}+1}-\Delta \mathrm{E}_{\mathrm{t}+1}-\Delta \mathrm{D}_{\mathrm{t}+2}-\Delta \mathrm{E}_{\mathrm{t}+2}$.

${ }^{18}$ The standard deviation of Current Depletion Dummy for the sample is 0.43 . A two standard deviation increase in this variable increases the likelihood of a debt issue by $31.4 \%$ and the likelihood of an equity issue by $11.5 \%$.
} 
A two standard deviation increase in Tobin's $\mathrm{Q}_{\mathrm{t}-1}$ decreases the likelihood of a debt issue by $2.7 \%$ and increases the likelihood of an equity issue by $2.1 \% .{ }^{19}$ A two standard deviation increase in the stock return in year t-1 increases the likelihood of a debt issue and the likelihood of an equity issue by $1.0 \%$ and $1.9 \%$, respectively. A two standard deviation increase in the stock return from $t+1$ to $t+3$ increases the likelihood of a debt issue by $0.4 \%$ and decreases the likelihood of an equity issue by $3.0 \%$, consistent with the market timing literature. Firms are less likely to issue debt and more likely to issue equity when the default spread is high, consistent with debt market timing. These economic effects are quantitatively much smaller than the effect of running out of cash for predicting external financing decisions.

Larger and older firms are less likely to issue equity, consistent with the lifecycle theory. A two standard deviation increase in firm size and age decreases the likelihood of equity issues by $5.6 \%$ and $2.9 \%$, respectively. High leverage firms are more likely to issue equity, consistent with the tradeoff theory. The economic effect of lagged leverage on equity issues is $3.2 \%$. Inconsistent with the tradeoff theory, however, the effect of lagged leverage on debt issues is negligible. This finding, together with our earlier finding of the primary importance of immediate cash needs for debt issues, is consistent with the findings in Denis and McKeon (2012), who conclude that most debt issues are motivated by an immediate need for cash rather than a desire to rebalance capital structure. $R \& D$ intensive firms, firms in industries with high cash flow volatility, and non-dividend payers are more likely to issue equity, consistent with the precautionary saving theory and with the static tradeoff theory.

\footnotetext{
${ }^{19}$ As discussed earlier, we require net issue size to be at least $5 \%$ of assets and $3 \%$ of market equity when defining a security issue. The economic effects of Tobin's $\mathrm{Q}_{\mathrm{t}-1}$ here are smaller than those in the literature (e.g., Huang and Ritter (2009)) that only require net issue size to be at least $5 \%$ of assets. For better comparison, we report the results that only require net issue size to be at least $5 \%$ of assets in Tables IA-5 and IA-6 in the Internet Appendix.
} 
Reverse-causality timing theories could also explain the importance of our ex post net cash flow measures (Baker, Stein, and Wurgler (2003)). That is, companies that raise external capital have lower $\mathrm{NCF}_{\mathrm{t}}$ because they spend more and are less aggressive at controlling costs, compared to if they had not raised external capital. To alleviate the reverse-causality concern, we replace $\mathrm{NCF}_{t}, \mathrm{NCF}_{\mathrm{t}+1}$, and $\mathrm{NCF}_{\mathrm{t}+2}$ with $\mathrm{NCF}_{\mathrm{t}-1}$ to define three dummy variables of cash depletion. In regression (2) of Table 7, Current Depletion Dummy ${ }_{\text {ex ante }}$ equals one if $\mathrm{Cash}_{\mathrm{t}-1}+\mathrm{NCF}_{\mathrm{t}-1} \leqslant 0$

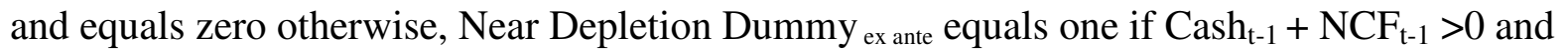
Cash $_{\mathrm{t}-1}+2 \times \mathrm{NCF}_{\mathrm{t}-1} \leqslant 0$ and equals zero otherwise, and Remote Depletion Dummy ex ante equals one if $\mathrm{Cash}_{\mathrm{t}-1}+\mathrm{NCF}_{\mathrm{t}-1}>0, \mathrm{Cash}_{\mathrm{t}-1}+2 \times \mathrm{NCF}_{\mathrm{t}-1}>0$, and $\mathrm{Cash}_{\mathrm{t}-1}+3 \times \mathrm{NCF}_{\mathrm{t}-1} \leqslant 0$ and equals zero otherwise. The ex ante measures of cash depletion in regression (2) are much less predictive than the ex post measures in regression (1), so we cannot rule out the effect of reverse causality on our ex post cash need measures. However, it is also likely that $\mathrm{NCF}_{\mathrm{t}-1}$ is not as good as $\mathrm{NCF}_{\mathrm{t}}$ in capturing expected cash needs. ${ }^{20}$ Reassuringly, the regression (2) results suggest that Current Depletion Dummy ex ante and Near Depletion Dummy ex ante are the primary predictors for debt issues and are important predictors for equity issues. The economic effects of Current Depletion Dummy $_{\text {ex ante }}$ on debt and equity issues are $13.4 \%$ and $7.5 \%$, respectively. The economic effects of Near Depletion Dummy ex ante on debt and equity issues are $7.2 \%$ and $6.6 \%$, respectively. These results suggest that the economic significance of our ex post measures of cash depletion is not simply due to reverse causality.

\footnotetext{
${ }^{20}$ Firms could raise capital later in a year to fund cash needs that become apparent earlier in the year. Our focus on Compustat annual data does not allow us to capture such effects. We thus check Compustat quarterly data to see if cash needs measured in the early quarters of a year increase the likelihood of issuing debt or equity in the later quarters of the year. We find that it is true, although the lagged quarter cash needs are less important than the current quarter cash needs in predicting debt and equity issues. The results using the quarterly data are otherwise qualitatively similar to the results using the annual data, and are reported in Tables IA-7 and IA-8 in the Internet Appendix.
} 
The economic effects of our control variables are sometimes quite different in regressions (1) and (2). For example, the economic effect of the year t-1 stock return on a debt issue is $1.0 \%$ in regression (1), and 5.5\% in regression (2). Such changes are partly because the correlations between our ex post cash depletion measures and the controls are different from the correlations between our ex ante measures of cash depletion and the controls.

Cash shortfalls can be the result of low beginning cash balances, low profitability, large investment expenditures, large increases in net working capital, or large cash dividends. Internet Appendix Table IA-9 examines whether the components of net cash flow have different relations with financing decisions. We find that $\mathrm{Cash}_{\mathrm{t}-1}, \mathrm{ICF}_{\mathrm{t}}$, Investments $\mathrm{t}$, and $\Delta \mathrm{Non}-\mathrm{Cash}_{\mathrm{NWC}}$, all scaled by Assets $\mathrm{t}_{\mathrm{t}-1}$, dominate other firm characteristics and market conditions in predicting the decision to issue debt. $\mathrm{ICF}_{\mathrm{t}}$, Investments $\mathrm{t}_{\mathrm{t}}$, and $\Delta \mathrm{Non}-\mathrm{Cash} \mathrm{NWC}_{\mathrm{t}}$, all scaled by Assets $\mathrm{t}_{\mathrm{t}-1}$, are also the most important predictors for the decision to issue equity. When only ex ante variables are used as independent variables, Cash $_{\mathrm{t}-1} \div$ Assets $_{\mathrm{t}-1}$ and Investments $_{\mathrm{t}-1} \div$ Assets $_{\mathrm{t}-1}$ are the two most important predictors for debt issues, and $\mathrm{ICF}_{\mathrm{t}-1} \div$ Assets $_{\mathrm{t}-1}$ is the most important predictor for equity issues. The Table IA-9 results are generally consistent with the Table 7 results, suggesting that cash needs are important motives for debt and equity issues.

$\mathrm{NCF}_{\mathrm{t}-1}$ is not an ideal measure for the expected net cash flows in $t, t+1$, and $t+2$. Firms are likely to use additional information to forecast net cash flows, and mean reversion in the net cash flow is also possible. Therefore, we use two alternative measures of expected net cash flows to define cash depletion, as we did in Panel B of Table 3, in the absence of external financing. First, we assume that a firm's expected net cash flows in $t, t+1$, and $t+2$, respectively, scaled by Assets $_{\mathrm{t}-1}$, are the same as the median net cash flow ratios of those in the same industry, the same tercile of Tobin's Q, and the same tercile of assets. Second, we estimate regressions using only 
ex ante information to predict the net cash flows, and use the fitted values as the expected net cash flows. Like the ex ante measures, the additional measures of cash depletion are less subject to a reverse-causality concern than the ex post measures. Internet Appendix Table IA-10 shows that these additional measures are still the most important determinants of debt issues. The median-based dummy variable for immediate cash depletion is more predictive for debt issues than Current Depletion Dummy ex ante, but other results are generally similar to those in regression (2) of Table 7.

\subsection{Securities issuances and cash changes}

Kim and Weisbach (2008) find that firms save 53.4 cents in cash for every dollar raised in the SEO (for every dollar raised, on average cash balances increase by 53.4 cents at the end of the fiscal year of the SEO), suggesting a timing-related stockpiling effect. They conclude that market timing plays an important role in SEO decisions. McLean (2011, Table 6) finds that one dollar of equity raised results in a saving of 56.4 cents, suggesting that precautionary savings are an important motive. Our number, in Panel $\mathrm{C}$ of Table 8, is a little higher, at 65.4 cents saved for every dollar of equity raised. In this subsection, we decompose the cash change into three components on the basis of fundamentals, timing opportunities, and other factors. We then relate the cash change and its components to securities issue proceeds in Table 8 .

Panel A of Table 8 reports regression results using the cash change in year $t \div$ Assets $_{\mathrm{t}-1}$ as the dependent variable, with fundamentals as the independent variables. We use $\mathrm{Cash}_{\mathrm{t}-1}, \Delta \mathrm{Non}-$ Cash Assets, $\mathrm{NCF}_{\mathrm{t}+1}$, and $\mathrm{NCF}_{\mathrm{t}+2}$, all scaled by Assets $\mathrm{t}-1$, as proxies for current and future cash self-sufficiency. We include $\Delta$ Non-Cash Assets $\div$ Assets $_{\mathrm{t}-1}$ instead of $\mathrm{NCF}_{\mathrm{t}} \div$ Assets $_{\mathrm{t}-1}$ to reduce the temporary effects of concurrent internal cash flow and cash uses on the optimal cash change. $\operatorname{Ln}(\text { Assets })_{\mathrm{t}-1}, \operatorname{Ln}(\text { Sales })_{\mathrm{t}-1}$, and $\operatorname{Ln}(\text { Age })_{\mathrm{t}}$ are lifecycle proxies. Leverage $\mathrm{t}_{\mathrm{t}-1}$ is a tradeoff proxy. 
$R \& D_{t-1}$, industry cash flow volatility $\mathrm{t}_{\mathrm{t}-1}$, and Dividend Payer $\mathrm{t}_{\mathrm{t}-1}$ are both precautionary saving and tradeoff theory proxies. We also include firm fixed effects and year dummy variables to capture other effects of fundamentals. The regressions are estimated for the full sample, equity issue sample, and debt issue sample, respectively.

Our results in Panel A are consistent with the literature on optimal cash holdings (Opler, Pinkowitz, Stulz, and Williamson (1999)). In all three regressions, firms with a higher Cash $_{t-1}$ $\div$ Assets $_{\mathrm{t}-1}$ and a smaller increase in non-cash assets are associated with a smaller cash increase. These results suggest that firms that need more cash increase cash by more, although reversecausality timing could also explain the results. Our proxies for future cash self-sufficiency, $\mathrm{NCF}_{\mathrm{t}+1} \div$ Assets $_{\mathrm{t}-1}$ and $\mathrm{NCF}_{\mathrm{t}+2} \div$ Assets $\mathrm{t}_{\mathrm{t}-1}$, are negatively related to the cash increase.

In all three regressions, the coefficients on $\mathrm{R} \& \mathrm{D}_{\mathrm{t}-1}$ are positive and statistically significant. In the debt issuing sample, regression (3), the coefficient on industry cash flow volatility is positive and statistically significant at the ten percent level. The findings are generally consistent with the precautionary saving theory.

The regressions in Panel B of Table 8 use the residuals from the regressions in Panel A as the dependent variable and timing proxies as the independent variables. Even after purging the effects of the proxies for fundamentals and reverse-causality timing, the timing proxies are important predictors for cash changes. Firms are more likely to increase cash when investors are optimistic about their future prospects. In all three regressions, the coefficients on Tobin's $\mathrm{Q}_{\mathrm{t}-1}$ are positive and statistically significant, with the coefficient on Tobin's $\mathrm{Q}_{\mathrm{t}-1}$ the largest for the equity issue sample. The coefficient on the stock return in year t-1 is positive and statistically significant in regression (1). The coefficients on the stock return from $t+1$ to $t+3$ are significantly negative in all three regressions. The coefficient is the largest for the equity issue sample, 
consistent with the literature on equity market timing. The coefficients on the default spread are positive and statistically significant in all regressions, suggesting that firms increase cash by more when the default spread is higher. For the debt issue sample, this positive relation is inconsistent with conditional market timing. Overall, the Panel B results suggest that conditional market timing is important in explaining equity issuance, but less so for debt issuance.

In Panel $\mathrm{C}$ of Table 8, we present the results of 12 regressions, expressed as rows rather than columns. Following Kim and Weisbach (2008) and McLean (2011), we first relate debt and equity issue proceeds to the cash change in regressions (1), (5), and (9). We then go one step further by linking debt and equity issue proceeds to three components of the cash change. The dependent variables in regressions (2), (6), and (10) are the fitted values from the Panel A regressions, capturing the effects of fundamentals and reverse-causality timing. The dependent variables in regressions (3), (7), and (11) are the fitted values from Panel B, capturing other market timing effects. The dependent variables in regressions (4), (8), and (12) are the residuals from Panel B, capturing other effects.

Regression (1) of Panel C for our full sample suggests that firms save 59.8 cents out of an extra dollar in the net equity issue proceeds. Regression (5) for the equity issue sample suggests that firms save 65.4 cents of a dollar of proceeds, and immediately spend 34.6 cents. The 59.8 and 65.4 cents numbers are not identical because the full sample includes firm-years in which an equity issue of less than $5 \%$ of assets or $3 \%$ of equity occurred.

In regressions (5a) and (5b), however, we split the sample of equity issuers into those with greater than or less than $\$ 200$ million in inflation-adjusted assets. The small firm issuers have a savings rate of 69.3 cents of an incremental dollar in proceeds, whereas the larger firm issuers have a savings rate of 40.6 cents. These results suggest that small firms, many of which 
are young and unprofitable, have a much greater tendency to save much of the proceeds of an equity issue, consistent with life cycle and precautionary savings motives, as well as the fixed costs of equity issuances that are not merely from employee stock option exercise.

Regression (6) suggests that a saving of 18.0 cents of an incremental dollar raised from equity is associated with the proxies for fundamentals and reverse-causality timing. So 52.6 cents (34.6 cents in spending +18.0 cents) can be attributed to immediate spending, the optimization of cash holdings, future cash needs, lifecycle and precautionary motives, and reverse-causality timing. Regression (7) suggests that our other timing proxies explain a saving of 9.1 cents of an incremental dollar. Reverse-causality timing does not explain the 9.1 cents because the effects of current and near-future cash needs have been purged. These findings are consistent with conditional market timing theories, which view both relative costs of capital and fundamentals as important. The unexplained saving of 38.2 cents in regression (8) could reflect market timing and fundamentals that we are unable to capture, or it could be the outcome of value-neutral forces. ${ }^{21}$

The finding that equity issuers save a large fraction of the issue proceeds is not inconsistent with the finding that near-term cash needs are a highly important trigger for equity issues. Although cash squeezes drive the decision to issue equity, by raising more than is immediately needed, equity issuers can save a large portion of the proceeds as cash.

Firms save a much smaller amount of a dollar in net debt issue proceeds. According to regressions (9)-(12) for the debt issue sample, firms save 14.1 cents of an extra dollar in net debt issue proceeds, with the proxies for fundamentals and reverse-causality timing explaining only 0.8 cents and our other timing proxies explaining only 2.3 cents of savings, respectively. These findings suggest that net debt issue proceeds are primarily used for immediate spending rather

\footnotetext{
${ }^{21} \mathrm{We}$ also examine whether the cash savings rate differs across firm characteristics and market conditions. We find that, for equity issuers, the savings rate of issuing proceeds is strongly related to proxies for precautionary savings and market conditions. The results are reported in Internet Appendix Table IA-11.
} 
than increasing cash balances, confirming our multinomial logit findings. Similarly, McLean and Palazzo (2017) find that debt issues are not associated with large cash increases, although they focus on gross debt issues rather than net debt issues.

\subsection{The choice between debt and equity, conditional on issuing and running out of cash}

Many firms that need cash can choose between issuing debt or equity. The market timing theory predicts that firms issue debt or equity depending upon their relative costs. The literature suggests that the cost of equity is low when Tobin's Q is high, the stock return in year t-1 is high, and the stock return from $t+1$ to $t+3$ is low; and the cost of debt is low when term spreads and default spreads are low (see Baker and Wurgler (2002), Huang and Ritter (2009), and DDS (2010)). In particular, the post-issue long-run stock performance has been extensively studied. ${ }^{22}$ The lifecycle theory predicts that younger firms are more likely to issue equity rather than debt. We use both firm sales and age as lifecycle proxies. The precautionary saving theory predicts that firms that face more uncertainties about future cash needs are more likely to issue equity rather than debt (Bates, Kahle, and Stulz (2009) and McLean (2011). Following the literature, we use $R \& D$ expense, industry cash flow volatility, and a dividend payer indicator as precautionary saving proxies. The tradeoff theory focuses on adjustments towards target leverage, and predicts that high leverage firms prefer equity issues over debt issues, other things being held equal.

Several papers examine the relation between financing deficits and surpluses and external financing, positing that firms with large deficits and surpluses will have lower adjustment costs and thus will move towards a target capital structure faster than other firms. In particular, Byoun (2008) and Faulkender, Flannery, Hankins and Smith (2012) report higher speeds of adjustment

\footnotetext{
${ }^{22}$ Daniel and Titman (2006), Hou, Xue, and Zhang (2015), and Lewis and Tan (2015) document that long-run stock performance is poor following composite equity issues, including SEOs, equity issues to employees, and equity issues in stock-financed acquisitions. Brophy, Ouimet, and Sialm (2009) document poor long-run stock performance following PIPEs.
} 
for firms with large financing deficits or surpluses. Unlike our paper, they do not focus on the decision to issue. Although these two papers do find that firms with large financing needs adjust their debt ratios more quickly, DeAngelo, DeAngelo, and Whited (2011) report that firms with investment spikes frequently issue debt that they then retire once the investment spike ends.

Table 9 reports multinomial logit regression results for the choice between a pure debt issue, a pure equity issue, and dual issues of debt and equity. Regression (1) uses the subsample of firms that issue a security. In regression (1), $\mathrm{ICF}_{\mathrm{t}-1}, \mathrm{Ln}(\mathrm{Sales})_{\mathrm{t}-1}$, Default Spread $_{\mathrm{t}-1}$, and Tobin's $\mathrm{Q}_{\mathrm{t}-1}$ are the most important predictors for the choice between debt and equity. ${ }^{23}$ As shown in Panel B of Table 9, a two standard deviation increase in the four variables is associated with a change in the likelihood of an equity issue of $-12.5 \%,-9.3 \%, 8.6 \%$, and $8.4 \%$, respectively. The negative coefficient on $\mathrm{ICF}_{\mathrm{t}-1}$ shows that firms with low internal cash flow are less likely to issue debt, consistent with the tradeoff theory, which predicts that high profitability firms issue debt rather than equity for tax benefits, and that firms with low profits are unlikely to issue debt, possibly due to the value-destroying risk-shifting incentives that would be created.

Consistent with the lifecycle theory, smaller and younger firms are more likely to issue equity instead of debt. Consistent with equity market timing, firms with a higher Tobin's Q, a higher stock return in $t-1$, and a lower stock return from $t+1$ to $t+3$ are more likely to issue equity rather than debt. Firms are less likely to issue debt when the default spread is high, consistent with debt market timing. But we should not overstate the importance of timing based on Tobin's Q, which could also capture other effects. The default spread result is at odds with the univariate sort results in Table 5, where there is no pattern. The economic effect of the stock return from

\footnotetext{
${ }^{23}$ Firms with a low ICF in $t-1$ could also have a low ICF in $t, t+1$, and $t+2$, so $\mathrm{ICF}_{\mathrm{t}-1}$ could capture not only year $\mathrm{t}$ cash needs, but also future cash needs and precautionary saving effects. However, inconsistent with the tax benefit of debt, we find that higher $\mathrm{ICF}_{\mathrm{t}-1} \div$ Assets $_{\mathrm{t}-1}$ firms are less likely to issue debt in a model for the joint decision of whether to issue and what security to issue (see Internet Appendix Table IA-8).
} 
$\mathrm{t}+1$ to $\mathrm{t}+3$, arguably the cleanest proxy for market timing, is only $-3.9 \%$. Consistent with the precautionary saving theory, firms with higher $R \& D$, firms in industries with higher cash flow volatility, and firms that do not pay dividends are more likely to issue equity rather than debt. Highly levered firms are more likely to issue equity rather than debt, consistent with the tradeoff theory. These findings are consistent with conditional timing theories that recognize the importance of both timing and fundamentals in the debt vs. equity choice.

To examine whether a cash squeeze limits a firm's ability to time the market, regression (2) is conditional on immediate cash depletion and issuing a security, where immediate cash depletion is identified using Cash ex post. $\operatorname{Ln}(\text { Sales })_{\mathrm{t}-1}$, Tobin's $\mathrm{Q}_{\mathrm{t}-1}$, and $\mathrm{R} \& \mathrm{D}_{\mathrm{t}-1}$ are the top three predictors in regression (2). The findings suggest that timing, lifecycle, precautionary saving, and static tradeoff theories are important in explaining the debt vs. equity choice even for firms that are running out of cash, whereas the pecking order theory predicts debt finance whenever possible. Reverse-causality timing may be partially responsible for the findings.

To alleviate the reverse-causality concern that firms spend more only because they have successfully raised capital, regression (3) relies on Cash ex ante to identify cash depletion. ${ }^{24}$ Reverse-causality timing theories predict that some firms are running out of cash on the basis of ex post spending but are not running out of cash on the basis of expected spending. This regression excludes such firms and uses only firms that are expected to run out of cash at $\mathrm{t}$ on the basis of ex ante information. $\operatorname{Ln}(\text { Sales })_{t-1}$, Tobin's $\mathrm{Q}_{\mathrm{t}-1}$, and $\mathrm{R} \& \mathrm{D}_{\mathrm{t}-1}$ are still the top three predictors for the debt vs. equity choice. The findings in regression (3) are consistent with

\footnotetext{
${ }^{24}{\text { Regression (1) includes } \text { Cash }_{\mathrm{t}-1} \div \text { Assets }_{\mathrm{t}-1}, \mathrm{ICF}_{\mathrm{t}-1} \div \text { Assets }_{\mathrm{t}-1} \text {, and Investments }}_{\mathrm{t}-1} \div$ Assets $_{\mathrm{t}-1}$ to control for immediate and near-future cash needs. Since regressions (2) and (3) use only firms that are running out of cash, the three control variables are not included. Our major results from regressions (2) and (3), however, are not qualitatively sensitive to whether they are included or not.
} 
conditional timing theories, but cannot be easily attributed to reverse-causality timing. ${ }^{25} \mathrm{~A}$ comparison of the results of regressions (2) and (3) suggest that reverse-causality timing does not have a material influence on the economic effects of the independent variables.

To further understand the relative importance of various determinants of the debt vs. equity choice, we also estimate regressions by removing either year dummy variables, industry dummy variables, timing proxies, lifecycle proxies, precautionary saving proxies, or the tradeoff proxy from the set of all independent variables. The pseudo $\mathrm{R}^{2}$, $\mathrm{s}$ of the regressions are reported at the bottom of Panel A of Table 9. The pseudo $\mathrm{R}^{2}$ is higher for a model with greater explanatory power. ${ }^{26}$ In each column, the specification without the timing proxies has a slightly lower pseudo $\mathrm{R}^{2}$ than the specification without the lifecycle proxies, suggesting that after controlling for funding needs, the market timing theory is slightly more important than the lifecycle theory in explaining the debt vs. equity choice. The pseudo $\mathrm{R}^{2 \text { s }} \mathrm{s}$ also suggest that the precautionary saving proxies are less predictive than either the timing proxies or the lifecycle proxies, and the tradeoff proxy has the lowest predictive power.

\section{Conclusions}

Welch (2004, p. 107) states that "corporate issuing motives themselves remain largely a mystery." In this paper, we show that a cash squeeze is the primary reason that U.S. firms raise cash externally, as predicted by the pecking order theory. Without raising external capital, $67.1 \%$ of issuers would have run out of cash before the end of the fiscal year. The pecking order theory

\footnotetext{
${ }^{25}$ To further alleviate the reverse-causality concern, we also estimate a regression using 12,174 debt or equity issuers with both Cash ex post $\leq 0$ and Cash ex ante $\leq 0$, and the results are similar to the results in regression (3).

${ }^{26}$ We report McFadden's pseudo $\mathrm{R}^{2}$. This statistic for a multinomial logit model does not mean what $\mathrm{R}^{2}$ means for an OLS model (the proportion of variance of the dependent variable that is explained by the independent variables). Although a $\mathrm{R}^{2}$ of 0.2 may indicate a poor fit of an OLS model, a McFadden's pseudo $\mathrm{R}^{2}$ ranging from 0.2 to 0.4 indicates a very good model fit. McFadden's pseudo $\mathrm{R}^{2}$ is best used to compare different specifications of the same model.
} 
explains $41.3 \%$ of equity issues, although other equity issues violate the pecking order because the firms either have cash or are running out of cash but plausibly could have issued debt instead. The static tradeoff model cannot explain why firms frequently wait until running out of cash to issue, although dynamic models with large issuance costs and reverse-causality timing models can. Even dynamic tradeoff models, however, have trouble explaining the low stock returns following equity issues. Market timing, lifecycle, and precautionary savings proxies explain a large portion of the choice between debt and equity financing when there is a choice.

DeAngelo, DeAngelo, and Stulz (2010) (DDS in this paper) report that $62.6 \%$ of SEO firms would have run out of cash at the end of year $t+1$ without the SEO proceeds in year $t$. If the net equity issuers in our sample, which includes firms raising equity capital using private placements, did not issue debt or equity, $54.4 \%$ of them would have run out of cash and $79.0 \%$ of them would have had a subnormal cash ratio at the end of the year. If they cut the net issuance size by half, rather than raising nothing, $34.7 \%$ would still have run out of cash. These findings support the importance of immediate cash needs for equity issuance.

Net debt issuers are even more likely to run out of cash than net equity issuers. If the net debt issuers in our sample did not issue a security, $76.1 \%$ of them would have run out of cash at the end of the year, and $90.3 \%$ of them would have had a subnormal cash ratio. If they cut the net issue size by half, rather than raising nothing, $58.4 \%$ of them would have run out of cash at the end of the year.

The above numbers are based on ex post actual internal cash flows and capital expenditures. The likelihoods of cash depletion are lower when using ex ante rather than ex post measures of cash needs. If the net cash flow in $\mathrm{t}$ is the same as that in $\mathrm{t}-1,44.8 \%$ of equity issuers and $43.1 \%$ of debt issuers would have otherwise run out of cash at the end of year $\mathrm{t}$. 
Even after controlling for other variables, immediate cash needs are the dominant predictor for debt issues. Using an ex post measure, firms that are running out of cash in a fiscal year are 11 times more likely to issue debt in the same year than firms that are not $(69.8 \%$ vs. 6.3\%). Using an ex ante measure avoids a reverse-causality concern, and we find that several alternative measures of immediate cash depletion are still the most important determinants of debt issues. Consistent with DDS (2010), we also find that immediate cash needs are highly important for equity issues, even after controlling for other variables. Using an ex post measure, the likelihoods of equity issuance by firms that are running out of cash and firms that are not differ by a factor of four, at $24.5 \%$ and $6.1 \%$, respectively. Using an ex ante measure instead, the likelihoods are $16.0 \%$ and $8.5 \%$, respectively. A predicted cash squeeze in year $\mathrm{t}+1$ also partly explains whether a firm will issue equity in year $\mathrm{t}$.

Net debt issuers immediately spend 85.9 cents of an incremental dollar in their net issuing proceeds. A desire to increase the firm's cash balances is simply not an important motive for debt issues. In comparison, net equity issuers immediately spend 34.6 cents of an incremental dollar in their net issuing proceeds, and those with at least $\$ 200$ million in assets spend 59.4 cents. Reverse-causality timing (firms spend more money because they have successfully raised money when the cost of capital is low) may be partly responsible for the spending. Our proxies for fundamentals and market timing can explain a large fraction of the savings, consistent with the conditional market timing theory.

Firms that are running out of cash and seeking external funding still choose between debt and equity. Conditional on issuing a security, firms with negative internal cash flow, small firms, R\&D intensive firms, and firms with a low cost of equity are the most likely to issue equity rather than debt, even for firms that are expected to run out of cash using ex ante information. In 
predicting the choice of debt vs. equity financing conditional on running out of cash, our proxies for market timing and lifecycle motives have comparable explanatory power, with our proxies for precautionary saving motives being less predictive. A caveat is in order, however, since some of our proxies for the various theories overlap or have multiple interpretations. For example, we use Tobin's Q as a proxy for market timing, but it also has been argued that in a static tradeoff framework, firms with a high Tobin's Q should use more equity to be able to exercise growth options.

In summary, most external financing occurs when a firm would otherwise have run out of cash, indicating a limit on theories which predict that adjusting leverage, stockpiling cash, or precautionary savings are the primary motive for issuing securities. Firms almost never borrow unless they will spend the money immediately. Equity issues are less frequent than debt issues, but when firms do issue equity they frequently raise enough to fund both immediate needs and needs for the next year or two. In explaining the choice between debt and equity financing, both economic fundamentals and market timing proxies are important, even for firms that are running out of cash. 


\section{References}

Baker, M., Stein, J., and Wurgler, J., 2003. When does the stock market matter? Stock prices and the investment of equity-dependent firms. Quarterly Journal of Economics 118, 969-1005.

Baker, M., and Wurgler, J., 2002. Market timing and capital structure. Journal of Finance 57, 132.

Bates, T., Kahle, K., and Stulz, R., 2009. Why do U.S. firms hold so much more cash than they used to? Journal of Finance 64, 1985-2021.

Brophy, D.J., Ouimet, P.P., and Sialm, C., 2009. Hedge funds as investors of last resort? Review of Financial Studies 22, 541-574.

Byoun, S., 2008, How and when do firms adjust their capital structures toward targets? Journal of Finance 63, 3069-3096.

Daniel, K., and Titman, S., 2006. Market reactions to tangible and intangible information. Journal of Finance 61, 1605-1643.

DeAngelo, H., DeAngelo, L., and Stulz, R. M., 2010. Seasoned equity offerings, market timing, and the corporate lifecycle. Journal of Financial Economics 95, 275-295.

DeAngelo, H., DeAngelo, L., and Whited, T. M., 2011. Capital structure dynamics and transitory debt. Journal of Financial Economics 99, 235-261.

Denis, D. J., and McKeon, S. B., 2012, Debt financing and financial flexibility: evidence from proactive leverage increases, Review of Financial Studies 25: 1897-1929.

Fama, E. F., and French, K. R., 2005. Financing decisions: Who issues stock? Journal of Financial Economics 76, 549-582.

Faulkender, M., Flannery, M. J., Hankins, K. W., and Smith, J. M., 2012, Cash flows and leverage adjustments. Journal of Financial Economics 103, 632-646.

Frank, M. Z., and Goyal, V. K., 2003. Testing the pecking order theory of capital structure. Journal of Financial Economics 67, 217-248.

Greenwood, R., and Hanson, S. G., 2012. Share issuance and factor timing, Journal of Finance 67, 761-798.

Gustafson, M., and Iliev, P., 2017. The effects of removing barriers to equity issuance. Journal of Financial Economics 124, 580-598. 
Hou, K., Xue, C., and Zhang, L., 2015. Digesting anomalies: An investment approach. Review of Financial Studies 28, 650-705.

Hovakimian, A., 2004. The role of target leverage in security issues and repurchases. Journal of Business 77, 1041-1071.

Hovakimian, A., Hovakimian, G., and Tehranian, H., 2004. Determinants of target capital structure: the case of dual debt and equity issuers. Journal of Financial Economics 71, 517540.

Huang, R., and Ritter, J. R., 2009. Testing theories of capital structure and estimating the speed of adjustment. Journal of Financial and Quantitative Analysis 44, 237-271.

Huang, R., and Ritter, J. R., 2017 The puzzle of frequent and large issues of debt and equity. Unpublished SSRN working paper.

Kim, W., and Weisbach, M. S., 2008. Motivations for public equity offers: an international perspective. Review of Financial Studies 87, 281-307.

Lewis, C. M., and Tan, Y., 2016. Debt-equity choices, R\&D investment and market timing. Journal of Financial Economics, 119, 599-610.

Loughran, T., and Ritter, J. R., 1995. The new issue puzzle. Journal of Finance 50, $23-51$.

McKeon, S. B., 2015, Employee option exercise and equity issuance motives. Unpublished SSRN working paper.

McLean, R. D., 2011, Share issuance and cash savings. Journal of Financial Economics 99, 693715 .

McLean, R. D., and Palazzo, B., 2017, The motives for long-term debt issues. Unpublished SSRN working paper.

Myers, S. C., 1984, The capital structure puzzle. Journal of Finance 39, 575-592.

Opler, T., Pinkowitz, L., Stulz, R., and Williamson, R., 1999. The determinants and implications of corporate cash holdings. Journal of Financial Economics 52, 3-46.

Strebulaev, I., and Yang, B., 2013, The mystery of zero-leverage firms. Journal of Financial Economics 109, 1-23.

Welch, I., 2004, Capital structure and stock returns. Journal of Political Economy 112, 106-131. 


\section{Appendix. Variable definitions}

Following Frank and Goyal (2003), we set some Compustat items to zero when they are missing or their Compustat data codes indicate that they are a combined figure or an insignificant figure.

\begin{tabular}{|c|c|}
\hline Variable name & Detailed definition \\
\hline$\overline{\Delta \mathrm{D}}$ & $\begin{array}{l}\text { The change in interest-bearing debt. For firms reporting format codes } 1 \text { to } 3, \Delta \mathrm{D} \\
=\text { Long-Term Debt Issuance (Compustat item DLTIS) - Long-Term Debt } \\
\text { Reduction (DLTR) - Current Debt Changes (DLCCH). For firms reporting } \\
\text { format code } 7, \Delta \mathrm{D}=\text { DLTIS - DLTR + DLCCH. }\end{array}$ \\
\hline$\Delta \mathrm{E}$ & $\begin{array}{l}\text { The change in equity from the statements of cash flow. } \Delta \mathrm{E}=\text { Sale of Common } \\
\text { and Preferred Stock (SSTK) - Purchase of Common and Preferred Stock } \\
\text { (PRSTKC). }\end{array}$ \\
\hline ICF & $\begin{array}{l}\text { Internal Cash Flow. For firms reporting format codes } 1 \text { to } 3, \text { ICF }=\text { Income } \\
\text { Before Extraordinary Items (IBC) + Extraordinary Items and Discontinued } \\
\text { Operations (XIDOC) + Depreciation and Amortization (DPC) + Deferred Taxes } \\
\text { (Changes) (TXDC) + Equity in Net Loss (Earnings) (ESUBC) + Sale of } \\
\text { Property Plant and Equipment and Investments Gain (Loss) (SPPIV) + Funds } \\
\text { from Operations Other (FOPO) + Sources of Funds Other (FSRCO). For firms } \\
\text { reporting format code } 7, \text { ICF = IBC + XIDOC + DPC + TXDC + ESUBC + } \\
\text { SPPIV + FOPO + Accounts Payable and Accrued Liabilities Increase (Decrease) } \\
\text { (APALCH). }\end{array}$ \\
\hline Investments & $\begin{array}{l}\text { For firms reporting format codes 1-3, Investments = Capital Expenditures } \\
\text { (CAPX) + Increase in Investments (IVCH) + Acquisitions (AQC) + Uses of } \\
\text { Funds Other (FUSEO) - Sale of Property (SPPE) - Sale of Investments (SIV). } \\
\text { For firms reporting format code 7, investments = CAPX + IVCH + AQC - SPPE } \\
\text { - SIV - Investing Activities Other (IVACO). }\end{array}$ \\
\hline ash & Cash Divide \\
\hline T & $\begin{array}{l}\text { Change in Net Working Capital. For firms reporting format codes 1-3, } \Delta \mathrm{NWC}= \\
\text { Working Capital Change Other (WCAPC) + Cash and Cash Equivalents } \\
\text { Increase (Decrease) }(\mathrm{CHECH}) \text {. For firms reporting format code } 7, \Delta \mathrm{NWC}=- \\
\text { Accounts Receivable Decrease (Increase) (RECCH) - Inventory Decrease } \\
\text { (Increase) (INVCH) - Accounts Payable and Accrued Liabilities Increase } \\
\text { (Decrease) (APALCH) - Income Taxes Accrued Increase (Decrease) (TXACH) } \\
\text { - Assets and Liabilities Other Net Change (AOLOCH) + Cash and Cash } \\
\text { Equivalents Increase (Decrease) (CHECH) - Change in Short-Term Investments } \\
\text { (IVSTCH) - Financing Activities Other (FIAO). }\end{array}$ \\
\hline ssets $_{\mathrm{t}-}$ & The book value of assets (item AT) at the end of fiscal year $t-1$. \\
\hline $\mathrm{ash}_{\mathrm{t}-1}$ & Cash and Short-Term In \\
\hline $\mathrm{Cash}_{\mathrm{t}}$ & $\mathrm{Cash}_{\mathrm{t}}-\mathrm{Cash}_{\mathrm{t}-1}$ \\
\hline$\Delta$ Non-Cash $\mathrm{NWC}_{\mathrm{t}}$ & $\Delta \mathrm{NWC}_{\mathrm{t}}-\Delta \mathrm{Cash}_{\mathrm{t}}$. \\
\hline Assets $_{\mathrm{t}}$ & Assets $_{t}-$ Assets $_{\mathrm{t}-1}$ \\
\hline$\Delta$ Non-Cash Assets $_{\mathrm{t}}$ & $\Delta$ Assets $_{\mathrm{t}}-\Delta$ Cash $_{\mathrm{t}}$ \\
\hline $\mathrm{NCF}_{\mathrm{t}}$ & $\begin{array}{l}\Delta \text { Cash }_{t}-\Delta D_{t}-\Delta E_{t} \text {, or equivalently, } \mathrm{ICF}_{\mathrm{t}}-\text { Investments }_{\mathrm{t}}-\Delta \text { Non-Cash } \mathrm{NWC}_{\mathrm{t}}- \\
\text { Cash Dividends } \mathrm{s}_{\mathrm{t}} \text { when the cash flow identity is satisfied. }\end{array}$ \\
\hline
\end{tabular}




\begin{tabular}{|c|c|}
\hline Variable name & Detailed definition \\
\hline Cash ex post & $\mathrm{Cash}_{\mathrm{t}-1}+\mathrm{NCF}_{\mathrm{t}}$ or $\mathrm{Cash}_{\mathrm{t}}-\Delta \mathrm{D}_{\mathrm{t}}-\Delta \mathrm{E}_{\mathrm{t}}$ \\
\hline Cash $_{\text {ex ante }}$ & $\operatorname{Cash}_{\mathrm{t}-1}+\mathrm{NCF}_{\mathrm{t}-1}$ or $2 \times \mathrm{Cash}_{\mathrm{t}-1}-\mathrm{Cash}_{\mathrm{t}-2}-\Delta \mathrm{D}_{\mathrm{t}-1}-\Delta \mathrm{E}_{\mathrm{t}-1}$. \\
\hline Tobin's $\mathrm{Q}_{\mathrm{t}-1}$ & $\begin{array}{l}\text { The sum of the market value of equity and the book value of debt (Common } \\
\text { Shares Outstanding (CSHO) } \times \text { Price Close Fiscal Year (PRCC_F) + Total } \\
\text { liabilities (LT) + Liquidating Value of Preferred Stock (PSTKL) - Deferred } \\
\text { Taxes and Investment Tax Credit (TXDITC)) at the end of fiscal year t- } 1 \div \\
\text { Assets }_{\text {t-1 }} \text {. When PSTKL is missing, the redemption value (PSTKRV) is used. } \\
\text { When PSTKRV is also missing, the carrying value (PSTK) is used. }\end{array}$ \\
\hline Return $_{\mathrm{t}-1}$ & The total return on the firm's stock in fiscal year $\mathrm{t}-1$. \\
\hline $\operatorname{Return}_{t+1, t+3}$ & $\begin{array}{l}\text { The total return on the firm's stock from fiscal year } t+1 \text { to fiscal year } t+3 \text {. If the } \\
\text { stock gets delisted before } 3 \text { years, the return until delisting is used. }\end{array}$ \\
\hline $\operatorname{Term~Spread}_{\mathrm{t}-1}(\%)$ & $\begin{array}{l}\text { The percentage yield difference between ten- and one-year constant fixed } \\
\text { maturity treasuries on the day immediately prior to the beginning of fiscal year t. }\end{array}$ \\
\hline $\begin{array}{l}\text { Default Spread } \text { t }-1 \\
(\%)\end{array}$ & $\begin{array}{l}\text { The percentage yield difference between Moody's Baa and Aaa rated corporate } \\
\text { bonds on the day immediately prior to the beginning of fiscal year } t \text {. }\end{array}$ \\
\hline $\operatorname{Ln}(\text { Sales })_{\mathrm{t}-1}$ & $\begin{array}{l}\text { The natural logarithm of net sales (SALE) during fiscal year t-1. Net sales is in } \\
\text { \$millions and is expressed in purchasing power at the end of } 2010 \text {. }\end{array}$ \\
\hline $\operatorname{Ln}(\text { Assets })_{\mathrm{t}-1}$ & $\begin{array}{l}\text { The natural logarithm of assets (item AT) during fiscal year t-1. Assets is in } \\
\text { \$millions and is expressed in purchasing power at the end of } 2010 \text {. }\end{array}$ \\
\hline $\operatorname{Ln}(\text { Age })_{\mathrm{t}}$ & The natural logarithm of the number of years the firm has been listed on CRSP. \\
\hline Leverage $_{t-1}$ & $\begin{array}{l}\text { The book value of debt (Total Liabilities (LT) + Minority Interest (MTB) - } \\
\text { Deferred Taxes and Investment Tax Credit (TXDITC) + Liquidating Value of } \\
\text { Preferred Stock (PSTKL) - Convertible Debt (DCVT)) } \div \text { the book value of total } \\
\text { assets (AT) at the end of fiscal year t- } 1 \text {. Note that DCVT is set to zero if it is } \\
\text { missing in Compustat. }\end{array}$ \\
\hline$R \& D_{t-1}$ & $\begin{array}{l}\text { Research and Development expenses (XRD) in year t-1 scaled by beginning-of- } \\
\text { year assets (AT). Firm-years for which this variable is missing are assigned a } \\
\text { value of zero. }\end{array}$ \\
\hline Industry Volatilityt-1 & $\begin{array}{l}\text { The average standard deviation of cash flow to assets of the firms with the same } \\
\text { two-digit SIC code. Cash flow is defined as (Operating Income Before } \\
\text { Depreciation (OIBDP) - Interest and Related Expense (XINT) - Income Taxes } \\
\text { (TXT) - Common Dividends (DVC)) } \div \text { beginning-of-year assets. For each firm, } \\
\text { the standard deviation of cash flow is computed for the ten years until the end of } \\
\text { year t-1, requiring at least three years of non-missing data. This definition } \\
\text { follows Bates, Kahle, and Stulz (2009). }\end{array}$ \\
\hline Dividend Payer $\mathrm{r}_{\mathrm{t}-1}$ & $\begin{array}{l}\text { A dummy variable that equals one if the firm pays a common dividend (DVC) in } \\
\text { year } t-1 \text {, and zero otherwise. }\end{array}$ \\
\hline $\mathrm{OIBD}_{\mathrm{t}-1}$ & $\begin{array}{l}\text { Operating income before depreciation }(\mathrm{OIBDP}) \text { in fiscal year t-1 scaled by } \\
\text { beginning-of-year assets }(\mathrm{AT}), \mathrm{OIBDP}_{\mathrm{t}-1} \div \text { Assets }_{\mathrm{t}-2} \text {. }\end{array}$ \\
\hline Industry Dummies & $\begin{array}{l}\text { Dummy variables using Ken French's } 17 \text { industry classification at } \\
\text { http://mba.tuck.dartmouth.edu/pages/faculty/ken.french/. The historical SIC } \\
\text { code from Compustat is used from } 1987 \text { and the CRSP historical SIC code is } \\
\text { used prior to } 1987 \text {. If both are missing, we use the header SIC code from } \\
\text { Compustat. }\end{array}$ \\
\hline
\end{tabular}




\section{Figure 1. Likelihood of cash depletion sorted by net issue size}

In Figure 1A, a firm is defined as running out of cash at the end of fiscal year $t$ if Cash ex post $\leqslant 0$, where Cash ex post $=\operatorname{Cash}_{t}-\Delta \mathrm{D}_{\mathrm{t}}-\Delta \mathrm{E}_{\mathrm{t}}=\mathrm{Cash}_{\mathrm{t}-1}+\mathrm{NCF}_{\mathrm{t}}$. In Figure 1B, a firm is defined as running out of cash at the end of fiscal year $t$ if Cash ex ante $\leqslant 0$, where Cash ex ante $=\mathrm{Cash}_{\mathrm{t}-1}+\mathrm{NCF}_{\mathrm{t}-1}$. Net issue size, net equity issue size, and net debt issue size are defined as $\left(\Delta \mathrm{E}_{\mathrm{t}}+\Delta \mathrm{D}_{\mathrm{t}}\right) \div$ Assets $_{\mathrm{t}-1}$, $\Delta \mathrm{E}_{\mathrm{t}} \div$ Assets $_{\mathrm{t}-1}$, and $\Delta \mathrm{D}_{\mathrm{t}} \div$ Assets $_{\mathrm{t}-1}$, respectively. See the Appendix for detailed variable definitions.
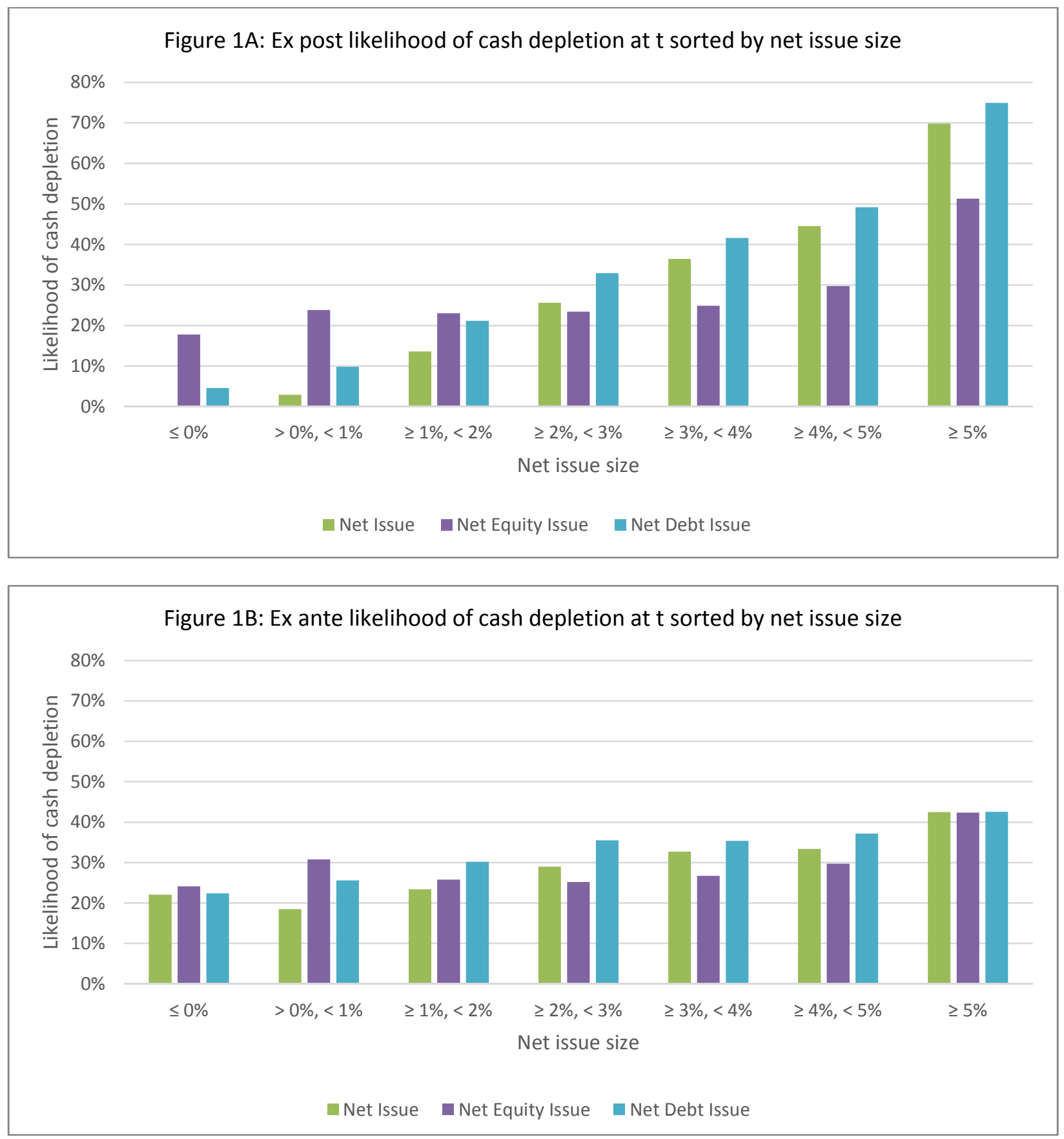


\section{Figure 2. Fraction of issuers that issue equity and average Tobin's $Q$ each year}

This figure shows for each fiscal year of 1972-2010 the fraction of issuers that have an equity issue in the year and the average Tobin's $Q$ at the end of the year for our sample firms. Note that average Tobin's $Q \div 5$ is plotted. The number of issuers in a fiscal year is the number of firms that have a debt issue or an equity issue in the year. A firm is defined to have an equity issue in year $\mathrm{t}$ if $\left(\Delta \mathrm{E}_{\mathrm{t}} \div\right.$ Assets $_{\mathrm{t}-1} \geqslant 0.05$ and $\left.\Delta \mathrm{E}_{\mathrm{t}} \div \mathrm{ME}_{\mathrm{t}-1} \geqslant 0.03\right)$. A firm is defined to have a debt issue if $\left(\Delta \mathrm{D}_{\mathrm{t}} \div\right.$ Assets $_{\mathrm{t}-1} \geqslant 0.05$ and $\left.\Delta \mathrm{D}_{\mathrm{t}} \div \mathrm{ME}_{\mathrm{t}-1} \geqslant 0.03\right)$. Assets $\mathrm{t}_{\mathrm{t}-1}$ and $\mathrm{ME}_{\mathrm{t}-1}$ denote the book value of assets and the market value of equity, respectively, at the end of fiscal year $\mathrm{t}-1$. The fraction of issuers that have an equity issue varies from 0.05 in 1974 to 0.65 in 2009 . The average Tobin's Q varies from 0.92 in 1974 to 2.25 in 1999 . The correlation between the fraction of issuers that have an equity issue and the average Tobin's Q is 0.74 for the 39 annual observations. See the Appendix for the detailed definitions of Tobin's $Q$ and other variables.

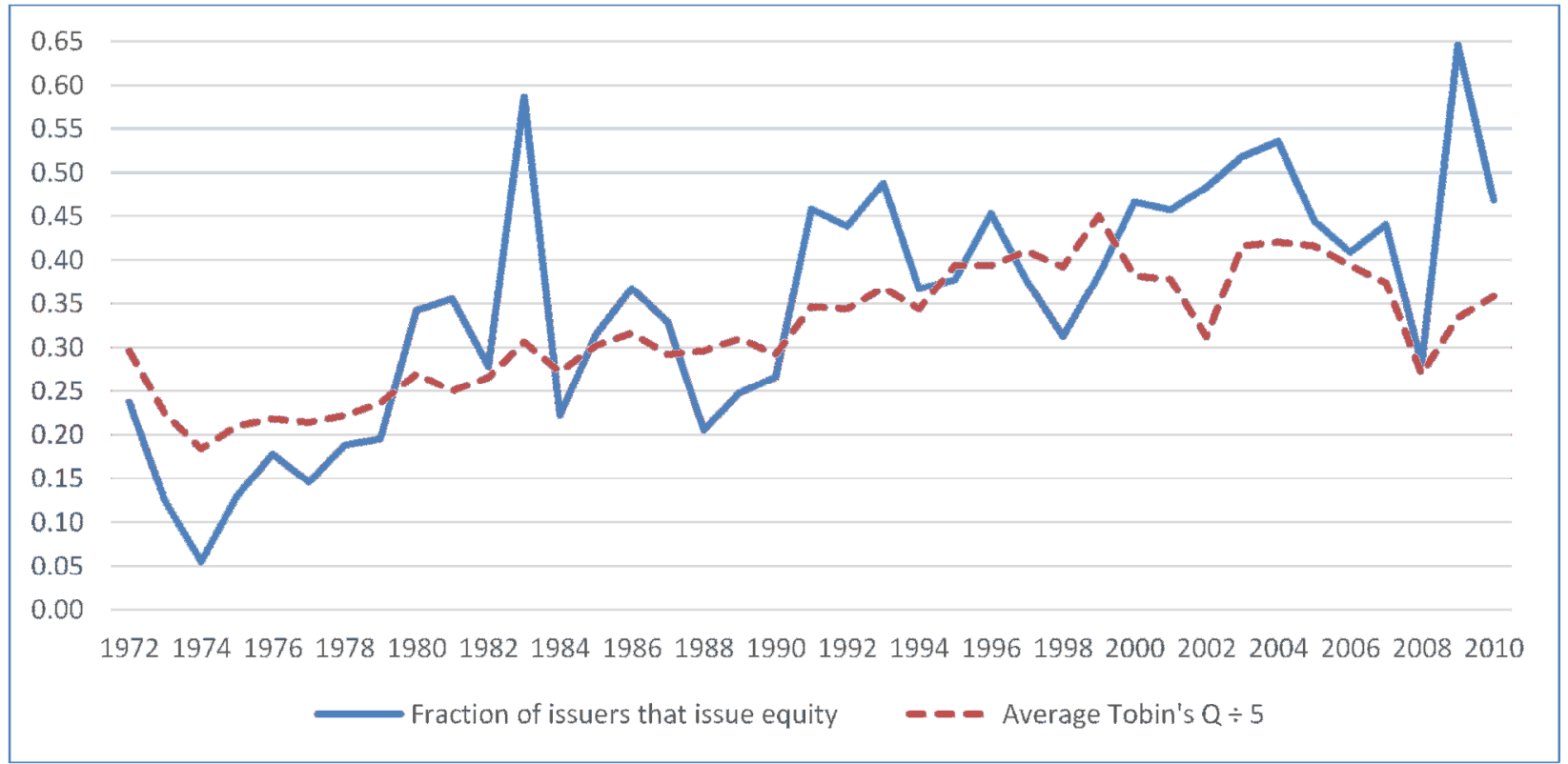




\section{Table 1. Sample distribution}

This table reports the distribution of our sample of CRSP- and Compustat-listed firms from 1972-2010. Utility and financial firms are excluded. Panel A reports the distribution by security issuance and choice. Panel B reports the distribution by cash depletion and issuing a security or not. Panel $\mathrm{C}$ reports the distribution by cash depletion and security choice. Panel D reports the probability of issuing, conditional on cash depletion or not. Panel E reports the probability of issuing debt or equity, conditional on running out of cash and issuing. $\mathrm{N}$ denotes the number of firm-year observations. $\%$ denotes the percent of firm-year observations in a group. A firm is defined to have a pure equity issue if $\left(\Delta \mathrm{E}_{\mathrm{t}} \div\right.$ Assets $_{\mathrm{t}-1} \geqslant 0.05$ and $\left.\Delta \mathrm{E}_{\mathrm{t}} \div \mathrm{ME} \mathrm{E}_{\mathrm{t}-1} \geqslant 0.03\right)$ and $\left(\Delta \mathrm{D}_{\mathrm{t}} \div\right.$ Assets $_{\mathrm{t}-1}<0.05$ or $\left.\Delta \mathrm{D}_{\mathrm{t}} \div \mathrm{ME}_{\mathrm{t}-1}<0.03\right)$. A firm is defined to have a pure debt issue if $\left(\Delta \mathrm{E}_{\mathrm{t}} \div\right.$ Assets $_{\mathrm{t}-1}$ $<0.05$ or $\left.\Delta \mathrm{E}_{\mathrm{t}} \div \mathrm{ME}_{\mathrm{t}-1}<0.03\right)$ and $\left(\Delta \mathrm{D}_{\mathrm{t}} \div\right.$ Assets $_{\mathrm{t}-1} \geqslant 0.05$ and $\left.\Delta \mathrm{D}_{\mathrm{t}} \div \mathrm{ME}_{\mathrm{t}-1} \geqslant 0.03\right)$. A firm is defined to have dual issues of debt and equity if $\left(\Delta \mathrm{E}_{\mathrm{t}} \div\right.$ Assets $_{\mathrm{t}-1} \geqslant 0.05$ and $\left.\Delta \mathrm{E}_{\mathrm{t}} \div \mathrm{ME}_{\mathrm{t}-1} \geqslant 0.03\right)$ and $\Delta \mathrm{D}_{\mathrm{t}} \div$ Assets $_{\mathrm{t}-1} \geqslant 0.05$ and $\Delta \mathrm{D}_{\mathrm{t}} \div \mathrm{ME}_{\mathrm{t}-1} \geqslant 0.03$ ). Assets $\mathrm{t}_{\mathrm{t}-1}$ and $\mathrm{ME}_{\mathrm{t}-1}$ denote the book value of assets and the market value of equity, respectively, at the end of fiscal year $\mathrm{t}-1$. Ex post cash depletion is defined as Cash ex post $\leq 0$, where Cash ex post $=\operatorname{Cash}_{t}-\Delta \mathrm{D}_{\mathrm{t}}-\Delta \mathrm{E}_{\mathrm{t}}$ (or equivalently, $\mathrm{Cash}_{\mathrm{t}-1}+\mathrm{ICF}_{\mathrm{t}}-$ Investments $_{t}-\Delta$ Non-Cash $\mathrm{NWC}_{\mathrm{t}}-$ Cash Dividends $\mathrm{t}_{\mathrm{t}}$ when the cash flow identity is satisfied). Ex ante cash depletion is defined as Cash ex ante $\leq 0$, where Cash ex ante $=\mathrm{Cash}_{\mathrm{t}-1}+\mathrm{NCF}_{\mathrm{t}-1}$. See the Appendix and Table 1 for detailed variable definitions.

Panel A. Distribution by security issuance and choice

\begin{tabular}{lrr}
\hline & $\mathrm{N}$ & $\%$ \\
\hline All firm-years & & \\
No security issue & 116,488 & 100.0 \\
Pure debt issue & 82,297 & 70.7 \\
Dual issues of debt and equity & 21,749 & 18.7 \\
Pure equity issue & 3,110 & 2.7 \\
& 9,332 & 8.0 \\
Conditional on issuing a security & & \\
Pure debt issue & 34,191 & 100.0 \\
Dual issues of debt and equity & 21,749 & 63.6 \\
Pure equity issue & 3,110 & 9.1 \\
\hline
\end{tabular}

Panel B. Distribution by cash depletion and issuing a security or not

\begin{tabular}{|c|c|c|c|c|c|c|c|}
\hline & \multicolumn{2}{|c|}{ All firms } & \multicolumn{2}{|c|}{ No security issue } & \multicolumn{2}{|c|}{ Security issue } \\
\hline & & $\mathrm{N}$ & $\%$ & $\mathrm{~N}$ & $\%$ & $\mathrm{~N}$ & $\%$ \\
\hline All & & 116,488 & 100.0 & 82,297 & 100.0 & 34,191 & 100.0 \\
\hline \multirow[t]{2}{*}{ Ex post cash depletion } & Yes & 28,304 & 24.3 & 5,356 & 6.5 & 22,948 & 67.1 \\
\hline & No & 88,184 & 75.7 & 76,941 & 93.5 & 11,243 & 32.9 \\
\hline \multirow[t]{2}{*}{ Ex ante cash depletion } & Yes & 33,248 & 28.5 & 18,757 & 22.8 & 14,491 & 42.4 \\
\hline & No & 83,240 & 71.5 & 63,540 & 77.2 & 19,700 & 57.6 \\
\hline
\end{tabular}


Panel C. Distribution by cash depletion and security choice

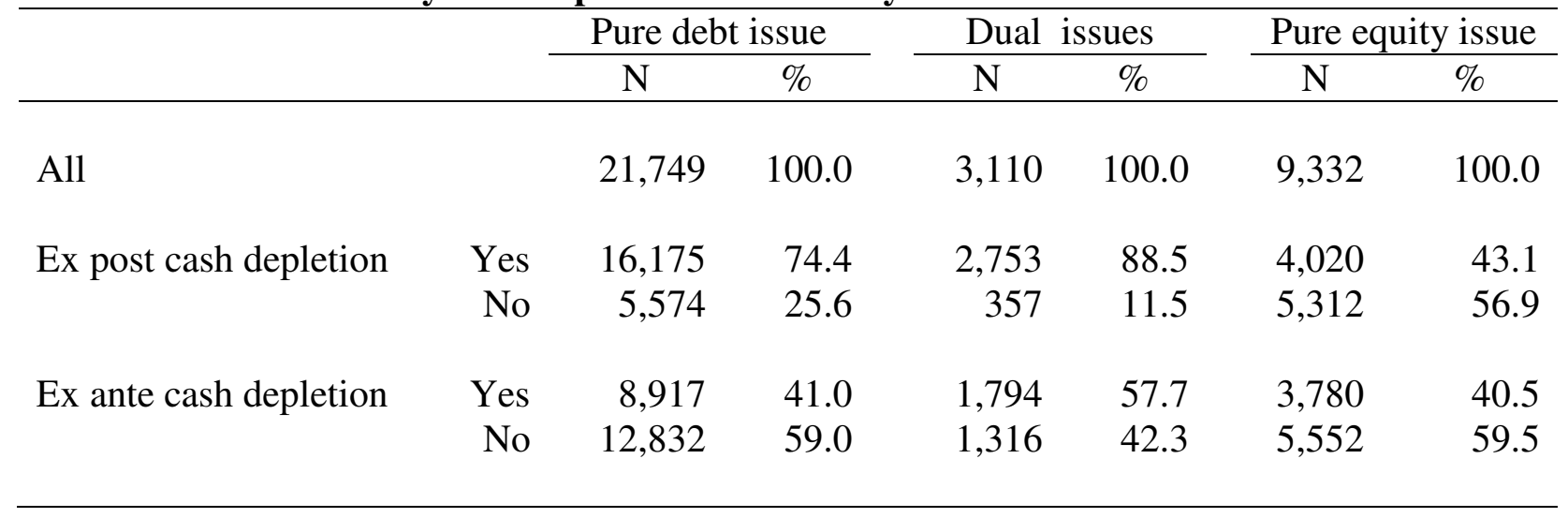

Panel D. Probability of issuing, conditional on cash depletion

\begin{tabular}{lcc}
\hline & Running out of cash & Not running out of cash \\
\hline Ex post measure & $22,948 \div 28,304=81.1 \%$ & $11,243 \div 88,184=12.7 \%$ \\
Ex ante measure & $14,491 \div 33,248=43.6 \%$ & $19,700 \div 83,240=23.7 \%$ \\
\hline
\end{tabular}

Panel E. Probability of issuing debt, equity, or both, conditional on ex post cash depletion and issuing

Debt issue

$18,928 \div 22,948=82.5 \%$

Equity issue

$6,773 \div 22,948=29.5 \%$

Dual issues of debt and equity

$2,753 \div 22,948=12.0 \%$ 


\section{Table 2. Summary statistics of annual cash flows (\%)}

This table reports summary statistics of annual cash flows (\%) for our sample of Compustat- and CRSP-listed firms from 1972-2010. Panel A reports the means and medians of the cash flow items (as a percent of the end of the prior fiscal year's assets). The medians are reported in the parentheses below the means. $\Delta \mathrm{D}_{\mathrm{t}}$ is the change in interest-bearing debt and $\Delta \mathrm{E}_{\mathrm{t}}$ is the change in equity from the statements of cash flow. ICF is internal cash flow, and NWC is net working capital. Panel B reports the summary statistics of cash change as a percent of net equity issue amount for equity issuers and cash change as a percent of net debt issue amount for debt issuers. $\%(\mathrm{X})$ denotes percent of equity issuers with $\Delta \mathrm{Cash}_{\mathrm{t}} \div \Delta \mathrm{E}_{\mathrm{t}}>\mathrm{X}$ or percent of debt issuers with $\Delta \operatorname{Cash}_{t} \div \Delta \mathrm{D}_{\mathrm{t}}>\mathrm{X}$. See the Appendix and Table 1 for detailed variable definitions.

Panel A. Mean and median annual cash flows (\%) sorted by security issues

\begin{tabular}{lccccc}
\hline & $\begin{array}{c}\text { No security } \\
\text { issue }\end{array}$ & $\begin{array}{c}\text { Pure debt } \\
\text { issue }\end{array}$ & $\begin{array}{c}\text { Dual } \\
\text { issues }\end{array}$ & $\begin{array}{c}\text { Pure equity } \\
\text { issue }\end{array}$ & All \\
\hline$\Delta \mathrm{D}_{\mathrm{t}} \div$ Assets $_{\mathrm{t}-1}$ & -1.9 & 18.3 & 30.4 & -4.8 & 2.5 \\
& $(-0.4)$ & $(12.2)$ & $(20.1)$ & $(-1.4)$ & $(0.0)$ \\
$\Delta \mathrm{E}_{\mathrm{t}} \div$ Assets $_{\mathrm{t}-1}$ & -0.4 & -0.7 & 29.3 & 37.7 & 3.4 \\
& $(0.0)$ & $(0.0)$ & $(18.3)$ & $(22.9)$ & $(0.0)$ \\
$\mathrm{ICF}_{\mathrm{t}} \div$ Assets $_{\mathrm{t}-1}$ & 10.3 & 10.4 & 3.7 & -0.5 & 9.3 \\
& $(10.7)$ & $(11.2)$ & $(10.0)$ & $(7.4)$ & $(10.6)$ \\
Investments $_{\mathrm{t}} \div$ Assets $_{\mathrm{t}-1}$ & 6.7 & 20.7 & 41.4 & 14.6 & 10.8 \\
& $(5.5)$ & $(15.4)$ & $(32.1)$ & $(8.8)$ & $(7.0)$ \\
Cash Dividends $_{\mathrm{t}} \div$ Assets $_{\mathrm{t}-1}$ & 1.2 & 1.0 & 0.7 & 0.5 & 1.1 \\
& $(0.1)$ & $(0.0)$ & $(0.0)$ & $(0.0)$ & $(0.0)$ \\
$\Delta \mathrm{NWC}_{\mathrm{t}} \div$ Assets $_{\mathrm{t}-1}$ & 0.3 & 6.3 & 17.9 & 17.4 & 3.3 \\
& $(0.8)$ & $(4.3)$ & $(9.8)$ & $(8.9)$ & $(1.7)$ \\
$\Delta$ Non-Cash $\mathrm{NWC}_{\mathrm{t}} \div$ Assets $_{\mathrm{t}-1}$ & 0.4 & 5.1 & 6.7 & 2.5 & 1.6 \\
& $(0.4)$ & $(3.3)$ & $(4.2)$ & $(1.8)$ & $(1.0)$ \\
$\Delta$ Cash $_{\mathrm{t}} \div$ Assets $_{\mathrm{t}-1}$ & -0.0 & 1.1 & 10.6 & 15.1 & 1.7 \\
& $(0.0)$ & $(0.1)$ & $(2.5)$ & $(4.5)$ & $(0.2)$ \\
\hline
\end{tabular}

Panel B. Cash change as a percent of net issue amount

\begin{tabular}{lrrrrrr}
\hline VARIABLES & Mean & Median & $\%(>25)$ & $\%(>50)$ & $\%(>75)$ & $\%(>100)$ \\
\hline Equity issuers: $\Delta$ Cash $_{\mathrm{t}} \div \Delta \mathrm{E}_{\mathrm{t}}(\%)$ & 31.5 & 19.0 & 46.1 & 32.4 & 21.4 & 13.2 \\
Debt issuers: $\Delta$ Cash $_{\mathrm{t}} \div \Delta \mathrm{D}_{\mathrm{t}}(\%)$ & 5.9 & 1.4 & 23.1 & 14.7 & 9.7 & 6.4 \\
\hline
\end{tabular}


Table 3. Cash, excess cash, and likelihoods of cash depletion

Panel A reports the mean and median cash and excess cash ratios for firms categorized by their security issuance in year $t$. The medians are reported in the parentheses below the means. In computing the excess cash ratios, Median Cash Ratio for a firm at the end of a fiscal year is defined as the median cash ratio for all firms in the same industry (using the two-digit SIC code), the same tercile of Tobin's Q, and the same tercile of assets at the end of the same year as the firm. Panel B reports the likelihoods (in percent) of cash depletion and the likelihoods of a subnormal cash ratio, conditional on the securities that are issued. $\mathrm{NCF}_{\mathrm{t}}=\Delta \mathrm{Cash}_{\mathrm{t}}-\Delta \mathrm{D}_{\mathrm{t}}-\Delta \mathrm{E}_{\mathrm{t}}$ (or equivalently, $\mathrm{ICF}_{\mathrm{t}}-$ Investments $_{\mathrm{t}}-\Delta$ Non-Cash $\mathrm{NWC}_{\mathrm{t}}-$ Cash Dividends $\mathrm{s}_{\mathrm{t}}$ when the cash flow identity is satisfied). $\mathrm{NCF}_{\mathrm{t}-1}, \mathrm{NCF}_{\mathrm{t}+1}$, and $\mathrm{NCF}_{\mathrm{t}+2}$ are similarly defined. By definition, $\mathrm{Cash}_{\mathrm{t}-1}+$ $\mathrm{NCF}_{\mathrm{t}}+\mathrm{NCF}_{\mathrm{t}+1}=\mathrm{Cash}_{\mathrm{t}+1}-\Delta \mathrm{D}_{\mathrm{t}}-\Delta \mathrm{E}_{\mathrm{t}}-\Delta \mathrm{D}_{\mathrm{t}+1}-\Delta \mathrm{E}_{\mathrm{t}+1}$ and $\mathrm{Cash}_{\mathrm{t}-1}+\mathrm{NCF}_{\mathrm{t}}+\mathrm{NCF}_{\mathrm{t}+1}+\mathrm{NCF}_{\mathrm{t}+2}=$ Cash $_{t+2}-\Delta \mathrm{D}_{\mathrm{t}}-\Delta \mathrm{E}_{\mathrm{t}}-\Delta \mathrm{D}_{\mathrm{t}+1}-\Delta \mathrm{E}_{\mathrm{t}+1}-\Delta \mathrm{D}_{\mathrm{t}+2}-\Delta \mathrm{E}_{\mathrm{t}+2}$. Gross Equity Issue $\mathrm{e}_{\mathrm{t}}$ quals Sale of Common and Preferred Stock (Compustat item SSTK) in year t. Median $\mathrm{NCF}_{\mathrm{t}}$ for a firm equals Assets $\mathrm{t}_{\mathrm{t}-1}$ of the firm times the median of $\mathrm{NCF}_{\mathrm{t}} \div$ Assets $_{\mathrm{t}-1}$ of all firms in the same industry (using the two-digit SIC code), the same tercile of Tobin's $\mathrm{Q}_{\mathrm{t}-1}$, and the same tercile of Assets $\mathrm{t}_{\mathrm{t}-1}$. Similarly, Median $\mathrm{NCF}_{t+1}$ equals Assets $\mathrm{t}_{\mathrm{t}-1}$ of the firm times the median of $\mathrm{NCF}_{\mathrm{t}+1} \div$ Assets $_{\mathrm{t}-1}$, and Median $\mathrm{NCF}_{\mathrm{t}+2}$ equals Assets $t_{t-1}$ of the firm times the median of $\mathrm{NCF}_{\mathrm{t}+2} \div$ Assets $_{\mathrm{t}-1}$. Fitted $\mathrm{NCF}_{\mathrm{t}}$ equals Assets $\mathrm{t}_{\mathrm{t}-1}$ times the fitted value from the regression using $\mathrm{NCF}_{\mathrm{t}} \div$ Assets $_{\mathrm{t}-1}$ as the dependent variable in the Internet Appendix Table IA-2. Similarly, Fitted $\mathrm{NCF}_{\mathrm{t}+1}$ equals Assets $\mathrm{t}_{-1}$ times the fitted value from the regression using $\mathrm{NCF}_{t+1} \div$ Assets $_{\mathrm{t}-1}$ as the dependent variable, and Fitted $\mathrm{NCF}_{\mathrm{t}+2}$ equals Assets $\mathrm{t}_{\mathrm{t}-1}$ times the fitted value from the regression using $\mathrm{NCF}_{\mathrm{t}+2} \div$ Assets $_{\mathrm{t}-1}$ as the dependent variable. See the Appendix and Table 1 for detailed variable definitions.

Panel A. Mean and median cash and excess cash ratios (\%)

\begin{tabular}{|c|c|c|c|c|c|c|c|}
\hline & $\begin{array}{c}\text { No } \\
\text { security } \\
\text { issue }\end{array}$ & $\begin{array}{l}\text { Pure } \\
\text { debt } \\
\text { issue }\end{array}$ & $\begin{array}{c}\text { Dual } \\
\text { issues }\end{array}$ & $\begin{array}{l}\text { Pure } \\
\text { equity } \\
\text { issue }\end{array}$ & $\begin{array}{c}\text { All } \\
\text { debt } \\
\text { issue }\end{array}$ & $\begin{array}{l}\text { All } \\
\text { equity } \\
\text { issue }\end{array}$ & All \\
\hline Cash $_{t-1} \div$ Assets $_{t-1}$ & $\begin{array}{l}15.4 \\
(8.2)\end{array}$ & $\begin{array}{c}9.0 \\
(4.6)\end{array}$ & $\begin{array}{l}13.6 \\
(6.4)\end{array}$ & $\begin{array}{l}23.5 \\
(11.9)\end{array}$ & $\begin{array}{c}9.6 \\
(4.8)\end{array}$ & $\begin{array}{c}21.0 \\
(10.1)\end{array}$ & $\begin{array}{l}14.8 \\
(7.4)\end{array}$ \\
\hline Cash $_{t} \div$ Assets $_{t}$ & $\begin{array}{l}15.0 \\
(8.2)\end{array}$ & $\begin{array}{l}7.7 \\
(3.7)\end{array}$ & $\begin{array}{l}14.0 \\
(6.7)\end{array}$ & $\begin{array}{c}27.1 \\
(18.1)\end{array}$ & $\begin{array}{c}8.5 \\
(4.0)\end{array}$ & $\begin{array}{c}23.8 \\
(13.9)\end{array}$ & $\begin{array}{l}14.5 \\
(7.3)\end{array}$ \\
\hline Cash $_{t+1} \div$ Assets $_{t+1}$ & $\begin{array}{l}15.1 \\
(8.3)\end{array}$ & $\begin{array}{c}7.8 \\
(3.8)\end{array}$ & $\begin{array}{l}12.6 \\
(5.5)\end{array}$ & $\begin{array}{c}24.9 \\
(14.8)\end{array}$ & $\begin{array}{c}8.4 \\
(4.0)\end{array}$ & $\begin{array}{c}21.9 \\
(11.4)\end{array}$ & $\begin{array}{l}14.4 \\
(7.3)\end{array}$ \\
\hline $\begin{array}{l}\text { Excess Cash }_{\mathrm{t}-1}: \\
\text { Cash }_{\mathrm{t}-1} \div \text { Assets }_{\mathrm{t}-1}-\text { Median Cash Ratio }_{\mathrm{t}-1}\end{array}$ & $\begin{array}{l}3.8 \\
(0.0)\end{array}$ & $\begin{array}{l}-0.3 \\
(-0.5)\end{array}$ & $\begin{array}{c}-0.3 \\
(-0.5)\end{array}$ & $\begin{array}{c}2.5 \\
(-0.0)\end{array}$ & $\begin{array}{l}-0.3 \\
(-0.5)\end{array}$ & $\begin{array}{c}1.8 \\
(-0.0)\end{array}$ & $\begin{array}{c}2.8 \\
(0.0)\end{array}$ \\
\hline $\begin{array}{l}\text { Excess Cash }_{t}: \\
\text { Cash }_{t} \div \text { Assets }_{t}-\text { Median Cash Ratio }\end{array}$ & $\begin{array}{c}3.4 \\
(0.0)\end{array}$ & $\begin{array}{c}-0.6 \\
(-0.7)\end{array}$ & $\begin{array}{c}0.8 \\
(-0.2)\end{array}$ & $\begin{array}{c}6.0 \\
(1.3)\end{array}$ & $\begin{array}{l}-0.4 \\
(-0.6)\end{array}$ & $\begin{array}{l}4.7 \\
(0.2)\end{array}$ & $\begin{array}{c}2.8 \\
(0.0)\end{array}$ \\
\hline $\begin{array}{l}{\text { Excess } \text { Cash }_{\mathrm{t}+1}:}^{\text {Cash }_{\mathrm{t}+1} \div \text { Assets }_{\mathrm{t}+1}-\text { Median Cash Ratio }_{\mathrm{t}+1}}\end{array}$ & $\begin{array}{c}3.4 \\
(0.0)\end{array}$ & $\begin{array}{c}-0.5 \\
(-0.6)\end{array}$ & $\begin{array}{c}0.4 \\
(-0.4)\end{array}$ & $\begin{array}{c}5.2 \\
(0.4)\end{array}$ & $\begin{array}{c}-0.4 \\
(-0.6)\end{array}$ & $\begin{array}{c}4.0 \\
(0.0)\end{array}$ & $\begin{array}{c}2.8 \\
(0.0)\end{array}$ \\
\hline
\end{tabular}


Panel B: Likelihoods of cash depletion (\%) with alternative NCF and financing assumptions

\begin{tabular}{|c|c|c|c|c|c|c|c|}
\hline & $\begin{array}{c}\text { No } \\
\text { security } \\
\text { issue }\end{array}$ & $\begin{array}{l}\text { Pure } \\
\text { debt } \\
\text { issue }\end{array}$ & $\begin{array}{c}\text { Dual } \\
\text { issues }\end{array}$ & $\begin{array}{l}\text { Pure } \\
\text { equity } \\
\text { issue }\end{array}$ & $\begin{array}{c}\text { All } \\
\text { debt } \\
\text { issue }\end{array}$ & $\begin{array}{l}\text { All } \\
\text { equity } \\
\text { issue }\end{array}$ & All \\
\hline \multicolumn{8}{|c|}{ Immediate cash depletion (running out of cash at the end of $t$ ): } \\
\hline (1) $\operatorname{Cash}_{\mathrm{t}}-\Delta \mathrm{D}_{\mathrm{t}}-\Delta \mathrm{E}_{\mathrm{t}} \leqslant 0 \quad\left(=\mathrm{Cash}_{\mathrm{t}-1}+\mathrm{NCF}_{\mathrm{t}} \leq 0\right)$ & 6.5 & 74.4 & 88.5 & 43.1 & 76.1 & 54.4 & 24.3 \\
\hline $\mathrm{sh}_{\mathrm{t}-1}+\mathrm{NCF}_{\mathrm{t}-1} \leq 0$ & 22.8 & 41.0 & 57.7 & 40.5 & 43.1 & 44.8 & 28.5 \\
\hline $\mathrm{NCF}<$ & 11.0 & 34.4 & 43.2 & 24.6 & 35.5 & 29.2 & 17.3 \\
\hline $5<0$ & 16.9 & 33.5 & 52.3 & 34.5 & 35.8 & 38.9 & 22.3 \\
\hline & 2.9 & 5.1 & 66.9 & 56.8 & 12.8 & 59.3 & 9.3 \\
\hline$(6$ & 6.5 & 78.1 & 67.3 & 2.9 & 76.7 & 19.0 & 21.2 \\
\hline & 3.6 & 56.9 & & 23.3 & 58.4 & 34.7 & 16.9 \\
\hline & 4.6 & 70.5 & 87.7 & 41.8 & 72.7 & 53.3 & 22.1 \\
\hline & 6.1 & 72.2 & 87.3 & 43.2 & 74.0 & 54.2 & 23.6 \\
\hline (10) Cash $_{t}-$ Gross Equity Issue $t \leq 0($ McLean (2011)) & 4.0 & 7.4 & 67.4 & 57.4 & 14.9 & 59.9 & 10.6 \\
\hline
\end{tabular}

Immediate subnormal cash ratio $(\leq$ the industry median cash ratio at the end of $t)$ :

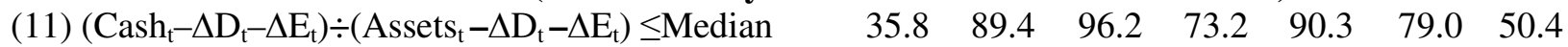

Cash Ratio or Cash $_{\mathrm{t}-1}+\mathrm{NCF}_{\mathrm{t}} \leq 0$

(12) $\left(\operatorname{Cash}_{\mathrm{t}-1}+\mathrm{NCF}_{\mathrm{t}-1}\right) \div\left[\right.$ Assets $_{\mathrm{t}-1}+\left(\Delta\right.$ Assets $_{\mathrm{t}-1}-\Delta \mathrm{D}_{\mathrm{t}-1}-$

$\begin{array}{lllllll}47.8 & 66.6 & 78.3 & 66.1 & 68.1 & 69.1 & 53.6\end{array}$

$\left.\left.\Delta \mathrm{E}_{\mathrm{t}-1}\right)\right] \leq$ Median Cash Ratio t $_{\mathrm{t}}$ or $\mathrm{Cash}_{\mathrm{t}-1}+\mathrm{NCF}_{\mathrm{t}-1} \leq 0$

(13) $\left[\right.$ Cash $\left._{\mathrm{t}}-0.5\left(\Delta \mathrm{D}_{\mathrm{t}}+\Delta \mathrm{E}_{\mathrm{t}}\right)\right] \div\left[\right.$ Assets $\left._{\mathrm{t}}-0.5\left(\Delta \mathrm{D}_{\mathrm{t}}+\Delta \mathrm{E}_{\mathrm{t}}\right)\right]$

$\begin{array}{lllllll}39.0 & 83.6 & 87.3 & 59.6 & 84.1 & 66.5 & 50.3\end{array}$

$\leq$ Median Cash Ratio or Cash $_{\mathrm{t}}-0.5\left(\Delta \mathrm{D}_{\mathrm{t}}+\Delta \mathrm{E}_{\mathrm{t}}\right) \leq 0$

Near-term cash depletion (running out of cash at the end of $t$ or $\mathbf{t}+1$ ):

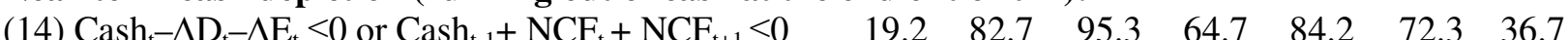

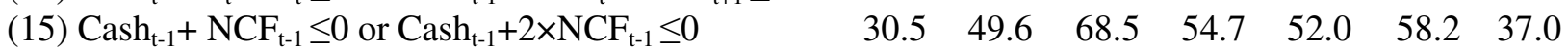

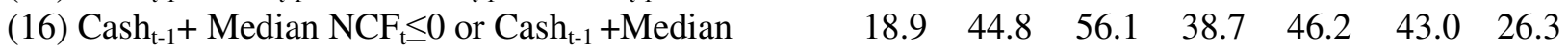

$\mathrm{NCF}_{\mathrm{t}}+$ Median $\mathrm{NCF}_{\mathrm{t}+1} \leq 0$

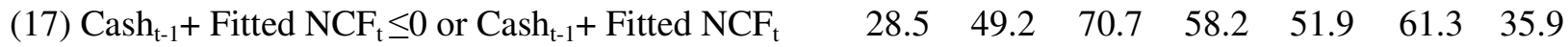

+ Fitted $\mathrm{NCF}_{\mathrm{t}+1} \leq 0$

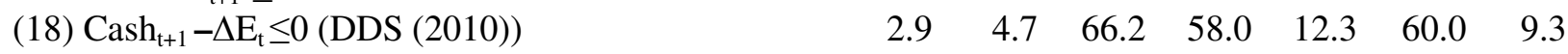

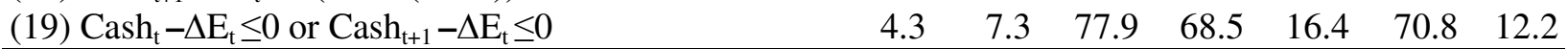

Near-future cash depletion (running out of cash at the end of $t+1$ but not at the end of $t$ ):

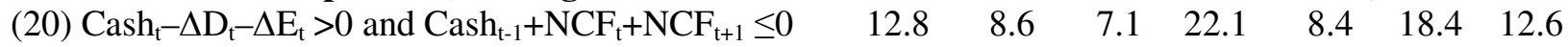

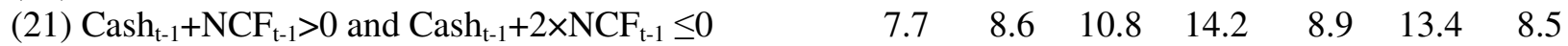

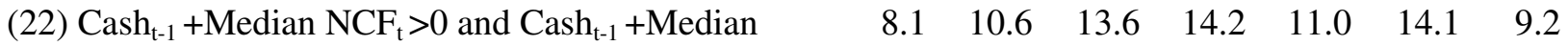

$\mathrm{NCF}_{\mathrm{t}}+$ Median $\mathrm{NCF}_{\mathrm{t}+1} \leq 0$

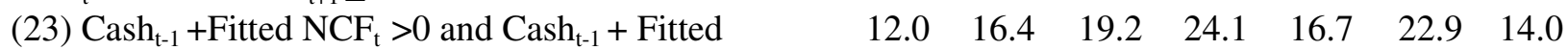

$\mathrm{NCF}_{\mathrm{t}}+$ Fitted $\mathrm{NCF}_{\mathrm{t}+1} \leq 0$

Remote-future cash depletion (running out of cash at the end of $t+2$ but not at the end of $t$ or $t+1$ ):

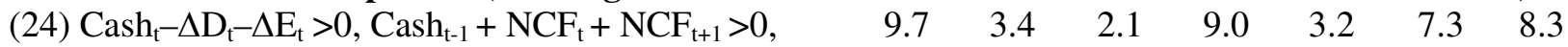

and $\mathrm{Cash}_{\mathrm{t}-1}+\mathrm{NCF}_{\mathrm{t}}+\mathrm{NCF}_{\mathrm{t}+1}+\mathrm{NCF}_{\mathrm{t}+2} \leq 0$

(25) $\mathrm{Cash}_{\mathrm{t}-1}+\mathrm{NCF}_{\mathrm{t}-1}>0, \mathrm{Cash}_{\mathrm{t}-1}+2 \times \mathrm{NCF}_{\mathrm{t}-1}>0$, and $\quad \begin{array}{lllllll}4.4 & 3.8 & 3.6 & 6.2 & 3.8 & 5.6 & 4.4\end{array}$

$\mathrm{Cash}_{\mathrm{t}-1}+3 \times \mathrm{NCF}_{\mathrm{t}-1} \leq 0$

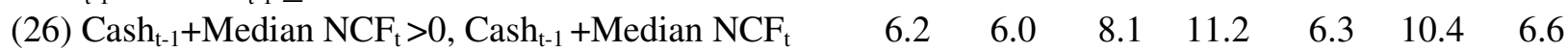

+ Median $\mathrm{NCF}_{\mathrm{t}+1}>0$, and $\mathrm{Cash}_{\mathrm{t}-1}+$ Median $\mathrm{NCF}_{\mathrm{t}}$

+ Median $\mathrm{NCF}_{\mathrm{t}+1}+$ Median $\mathrm{NCF}_{\mathrm{t}+2} \leq 0$

(27) $\mathrm{Cash}_{\mathrm{t}-1}+$ Fitted $\mathrm{NCF}_{\mathrm{t}}>0$, $\mathrm{Cash}_{\mathrm{t}-1}+$ Fitted $\mathrm{NCF}_{\mathrm{t}}$

+ Fitted $\mathrm{NCF}_{\mathrm{t}+1}>0$, and $\mathrm{Cash}_{\mathrm{t}-1}+$ Fitted $\mathrm{NCF}_{\mathrm{t}}+$ Fitted

$\begin{array}{lllllll}9.9 & 9.0 & 7.8 & 14.1 & 8.9 & 12.6 & 10.0\end{array}$

$\mathrm{NCF}_{\mathrm{t}+1}+$ Fitted $\mathrm{NCF}_{\mathrm{t}+2} \leq 0$ 
Table 4. Means and medians of control variables sorted by security issues

This table reports the means and medians of the control variables. The medians are reported in the parentheses below the means. See the Appendix and Table 1 for detailed variable definitions.

Panel A. All firms $(\mathrm{N}=116,488)$

\begin{tabular}{|c|c|c|c|c|c|}
\hline VARIABLES & No security issue & Pure debt issue & Dual issues & Pure equity issue & All \\
\hline Tobin's $\mathrm{Q}_{\mathrm{t}-1}$ & $\begin{array}{c}1.6 \\
(1.2)\end{array}$ & $\begin{array}{c}1.6 \\
(1.3)\end{array}$ & $\begin{array}{c}2.1 \\
(1.7)\end{array}$ & $\begin{array}{c}2.6 \\
(1.9)\end{array}$ & $\begin{array}{r}1.7 \\
(1.3)\end{array}$ \\
\hline $\operatorname{Return}_{\mathrm{t}-1}(\%)$ & $\begin{array}{l}17.1 \\
(5.0)\end{array}$ & $\begin{array}{c}23.0 \\
(11.3)\end{array}$ & $\begin{array}{c}46.7 \\
(20.7)\end{array}$ & $\begin{array}{c}44.8 \\
(14.8)\end{array}$ & $\begin{array}{l}21.2 \\
(7.0)\end{array}$ \\
\hline Return $_{\mathrm{t}+1, \mathrm{t}+3}(\%)$ & $\begin{array}{c}60.3 \\
(28.8)\end{array}$ & $\begin{array}{c}44.5 \\
(14.4)\end{array}$ & $\begin{array}{c}10.5 \\
(-24.8)\end{array}$ & $\begin{array}{c}14.9 \\
(-18.8)\end{array}$ & $\begin{array}{r}52.4 \\
(21.8)\end{array}$ \\
\hline Term Spread $_{t-1}(\%)$ & $\begin{array}{c}1.1 \\
(1.0)\end{array}$ & $\begin{array}{c}1.0 \\
(0.8)\end{array}$ & $\begin{array}{l}1.0 \\
(0.9)\end{array}$ & $\begin{array}{c}1.2 \\
(1.1)\end{array}$ & $\begin{array}{r}1.1 \\
(1.0)\end{array}$ \\
\hline 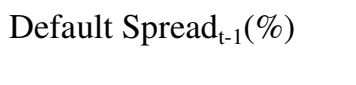 & $\begin{array}{c}1.1 \\
(1.0)\end{array}$ & $\begin{array}{c}1.1 \\
(1.0)\end{array}$ & $\begin{array}{c}1.1 \\
(1.0)\end{array}$ & $\begin{array}{c}1.1 \\
(1.0)\end{array}$ & $\begin{array}{r}1.1 \\
(1.0)\end{array}$ \\
\hline $\operatorname{Ln}(\text { Sales })_{t-1}$ & $\begin{array}{c}5.9 \\
(5.8)\end{array}$ & $\begin{array}{c}5.9 \\
(5.8)\end{array}$ & $\begin{array}{c}4.7 \\
(4.7)\end{array}$ & $\begin{array}{c}4.3 \\
(4.3)\end{array}$ & $\begin{array}{r}5.8 \\
(5.7)\end{array}$ \\
\hline $\operatorname{Ln}(\text { Age })_{t}$ & $\begin{array}{c}2.5 \\
(2.5)\end{array}$ & $\begin{array}{c}2.3 \\
(2.3)\end{array}$ & $\begin{array}{c}2.0 \\
(2.0)\end{array}$ & $\begin{array}{c}2.1 \\
(2.0)\end{array}$ & $\begin{array}{r}2.4 \\
(2.4)\end{array}$ \\
\hline Leverage $_{t-1}(\%)$ & $\begin{array}{c}44.9 \\
(43.7)\end{array}$ & $\begin{array}{c}49.4 \\
(48.1)\end{array}$ & $\begin{array}{c}54.3 \\
(52.3)\end{array}$ & $\begin{array}{c}47.5 \\
(44.6)\end{array}$ & $\begin{array}{r}46.2 \\
(45.0)\end{array}$ \\
\hline $\mathrm{R} \& \mathrm{D}_{\mathrm{t}-1}(\%)$ & $\begin{array}{c}3.8 \\
(0.0)\end{array}$ & $\begin{array}{c}2.6 \\
(0.0)\end{array}$ & $\begin{array}{c}6.2 \\
(0.0)\end{array}$ & $\begin{array}{l}11.6 \\
(2.7)\end{array}$ & $\begin{array}{r}4.2 \\
(0.0)\end{array}$ \\
\hline Industry Volatility $_{\mathrm{t}-1}(\%)$ & $\begin{array}{c}17.9 \\
(11.8)\end{array}$ & $\begin{array}{c}15.2 \\
(10.5)\end{array}$ & $\begin{array}{c}19.3 \\
(14.2)\end{array}$ & $\begin{array}{c}24.4 \\
(20.5)\end{array}$ & $\begin{array}{r}17.9 \\
(12.0)\end{array}$ \\
\hline Dividend Payer $_{\mathrm{t}-1}(\%)$ & 47.7 & 45.8 & 24.0 & 17.4 & 44.3 \\
\hline
\end{tabular}

Panel B. Firms that are running out of cash and issuing a security in $t$

\begin{tabular}{|c|c|c|c|c|c|c|c|c|}
\hline \multirow[b]{2}{*}{ VARIABLES } & \multicolumn{4}{|c|}{ Cash $_{\text {ex post }} \leqslant 0(\mathrm{~N}=22,948)$} & \multicolumn{4}{|c|}{ Cash $_{\text {ex ante }} \leqslant 0(\mathrm{~N}=14,491)$} \\
\hline & $\begin{array}{l}\text { Pure debt } \\
\text { issue }\end{array}$ & $\begin{array}{l}\text { Dual } \\
\text { issues }\end{array}$ & $\begin{array}{c}\text { Pure equity } \\
\text { issue }\end{array}$ & All & $\begin{array}{c}\text { Pure debt } \\
\text { issue }\end{array}$ & $\begin{array}{l}\text { Dual } \\
\text { issues }\end{array}$ & $\begin{array}{c}\text { Pure equity } \\
\text { issue }\end{array}$ & All \\
\hline Tobin's $\mathrm{Q}_{\mathrm{t}-1}$ & $\begin{array}{c}1.5 \\
(1.3)\end{array}$ & $\begin{array}{c}2.1 \\
(1.6)\end{array}$ & $\begin{array}{c}2.8 \\
(1.9)\end{array}$ & $\begin{array}{c}1.8 \\
(1.4)\end{array}$ & $\begin{array}{c}1.6 \\
(1.3)\end{array}$ & $\begin{array}{c}2.1 \\
(1.7)\end{array}$ & $\begin{array}{c}2.6 \\
(1.8)\end{array}$ & $\begin{array}{c}1.9 \\
(1.4)\end{array}$ \\
\hline $\operatorname{Return}_{\mathrm{t}-1}(\%)$ & $\begin{array}{c}23.2 \\
(11.3)\end{array}$ & $\begin{array}{c}46.7 \\
(22.0)\end{array}$ & $\begin{array}{c}48.8 \\
(16.7)\end{array}$ & $\begin{array}{c}30.5 \\
(13.0)\end{array}$ & $\begin{array}{l}16.0 \\
(5.7)\end{array}$ & $\begin{array}{c}36.6 \\
(15.0)\end{array}$ & $\begin{array}{l}25.6 \\
(2.3)\end{array}$ & $\begin{array}{l}21.1 \\
(5.9)\end{array}$ \\
\hline $\operatorname{Return}_{\mathrm{t}+1, \mathrm{t}+3}(\%)$ & $\begin{array}{c}42.7 \\
(11.7)\end{array}$ & $\begin{array}{c}8.7 \\
(-25.8)\end{array}$ & $\begin{array}{c}2.8 \\
(-31.9)\end{array}$ & $\begin{array}{l}31.6 \\
(0.5)\end{array}$ & $\begin{array}{l}37.7 \\
(6.0)\end{array}$ & $\begin{array}{c}5.0 \\
(-33.3)\end{array}$ & $\begin{array}{c}10.7 \\
(-26.9)\end{array}$ & $\begin{array}{l}26.6 \\
(-6.0)\end{array}$ \\
\hline $\operatorname{Term}_{\operatorname{Spread}_{\mathrm{t}-1}(\%)}$ & $\begin{array}{c}0.9 \\
(0.8)\end{array}$ & $\begin{array}{c}1.0 \\
(0.8)\end{array}$ & $\begin{array}{c}1.1 \\
(0.9)\end{array}$ & $\begin{array}{c}0.9 \\
(0.8)\end{array}$ & $\begin{array}{c}0.9 \\
(0.7)\end{array}$ & $\begin{array}{c}0.9 \\
(0.7)\end{array}$ & $\begin{array}{c}1.1 \\
(0.9)\end{array}$ & $\begin{array}{c}0.9 \\
(0.8)\end{array}$ \\
\hline Default Spread $_{\mathrm{t}-1}(\%)$ & $\begin{array}{c}1.0 \\
(1.0)\end{array}$ & $\begin{array}{c}1.1 \\
(1.0)\end{array}$ & $\begin{array}{c}1.1 \\
(0.9)\end{array}$ & $\begin{array}{c}1.1 \\
(0.9)\end{array}$ & $\begin{array}{c}1.0 \\
(0.9)\end{array}$ & $\begin{array}{c}1.1 \\
(0.9)\end{array}$ & $\begin{array}{c}1.1 \\
(0.9)\end{array}$ & $\begin{array}{c}1.1 \\
(0.9)\end{array}$ \\
\hline $\operatorname{Ln}(\text { Sales })_{t-1}$ & $\begin{array}{c}5.8 \\
(5.7)\end{array}$ & $\begin{array}{c}4.7 \\
(4.7)\end{array}$ & $\begin{array}{c}4.1 \\
(4.1)\end{array}$ & $\begin{array}{c}5.4 \\
(5.4)\end{array}$ & $\begin{array}{c}5.6 \\
(5.6)\end{array}$ & $\begin{array}{c}4.5 \\
(4.5)\end{array}$ & $\begin{array}{c}4.2 \\
(4.1)\end{array}$ & $\begin{array}{c}5.1 \\
(5.1)\end{array}$ \\
\hline $\operatorname{Ln}(\text { Age })_{t}$ & $\begin{array}{c}2.3 \\
(2.3)\end{array}$ & $\begin{array}{c}2.0 \\
(2.0)\end{array}$ & $\begin{array}{c}2.0 \\
(1.9)\end{array}$ & $\begin{array}{c}2.2 \\
(2.2)\end{array}$ & $\begin{array}{c}2.2 \\
(2.2)\end{array}$ & $\begin{array}{c}1.9 \\
(1.9)\end{array}$ & $\begin{array}{c}2.0 \\
(2.0)\end{array}$ & $\begin{array}{c}2.1 \\
(2.1)\end{array}$ \\
\hline Leverage $_{\mathrm{t}-1}(\%)$ & $\begin{array}{c}50.9 \\
(49.6)\end{array}$ & $\begin{array}{c}55.5 \\
(53.7)\end{array}$ & $\begin{array}{c}51.1 \\
(48.9)\end{array}$ & $\begin{array}{c}51.5 \\
(49.9)\end{array}$ & $\begin{array}{c}53.0 \\
(51.7)\end{array}$ & $\begin{array}{c}57.7 \\
(55.4)\end{array}$ & $\begin{array}{c}54.4 \\
(51.8)\end{array}$ & $\begin{array}{c}54.0 \\
(52.1)\end{array}$ \\
\hline $\mathrm{R} \& \mathrm{D}_{\mathrm{t}-1}(\%)$ & $\begin{array}{c}2.1 \\
(0.0)\end{array}$ & $\begin{array}{c}5.2 \\
(0.0)\end{array}$ & $\begin{array}{c}9.6 \\
(0.4)\end{array}$ & $\begin{array}{c}3.8 \\
(0.0)\end{array}$ & $\begin{array}{c}2.4 \\
(0.0)\end{array}$ & $\begin{array}{c}5.8 \\
(0.0)\end{array}$ & $\begin{array}{l}9.8 \\
(0.8)\end{array}$ & $\begin{array}{c}4.7 \\
(0.0)\end{array}$ \\
\hline Industry Volatility $_{\mathrm{t}-1}(\%)$ & $\begin{array}{l}14.0 \\
(9.9)\end{array}$ & $\begin{array}{c}18.1 \\
(13.8)\end{array}$ & $\begin{array}{c}21.0 \\
(16.3)\end{array}$ & $\begin{array}{c}15.7 \\
(11.2)\end{array}$ & $\begin{array}{c}14.0 \\
(10.3)\end{array}$ & $\begin{array}{c}19.1 \\
(14.4)\end{array}$ & $\begin{array}{c}22.3 \\
(16.9)\end{array}$ & $\begin{array}{c}16.8 \\
(11.9)\end{array}$ \\
\hline Dividend Payer $_{\mathrm{t}-1}(\%)$ & 45.5 & 25.2 & 18.2 & 38.3 & 40.9 & 20.7 & 17.5 & 32.3 \\
\hline
\end{tabular}




\section{Table 5. Likelihood of security issues sorted by firm characteristics}

This table reports the likelihoods (in percent) of security issues in year $t$ for the subgroups sorted by firm characteristics. The cutoff points are determined each fiscal year. The likelihoods for all debt issues are the sums of the likelihoods of pure debt issues and dual issues. The likelihoods for all equity issues are the sums of the likelihoods of pure equity issues and dual issues. See the Appendix and Table 1 for detailed variable definitions.

\begin{tabular}{|c|c|c|c|c|c|c|}
\hline & $\begin{array}{l}\text { No security } \\
\text { issue }\end{array}$ & $\begin{array}{l}\text { Pure debt } \\
\text { issue }\end{array}$ & $\begin{array}{l}\text { Dual } \\
\text { issues }\end{array}$ & $\begin{array}{l}\text { Pure equity } \\
\text { issue }\end{array}$ & $\begin{array}{l}\text { All debt } \\
\text { issue }\end{array}$ & $\begin{array}{l}\text { All equity } \\
\text { issue }\end{array}$ \\
\hline All & 70.7 & 18.7 & 2.7 & 8.0 & 21.4 & 10.7 \\
\hline \multicolumn{7}{|c|}{ Cash $_{\mathrm{t}-1} \div$ Assets $_{\mathrm{t}-1}$ Quartile: } \\
\hline 1 (low) & 66.3 & 24.6 & 2.8 & 6.4 & 27.4 & 9.2 \\
\hline 2 & 67.6 & 22.8 & 3.0 & 6.7 & 25.8 & 9.7 \\
\hline 3 & 72.6 & 17.6 & 2.7 & 7.1 & 20.3 & 9.8 \\
\hline 4 (high) & 76.1 & 9.8 & 2.3 & 11.9 & 12.1 & 14.2 \\
\hline \multicolumn{7}{|c|}{ Cash $_{\text {ex post }} \div$ Assets $_{\mathrm{t}-1}$ Quartile: } \\
\hline 1 & 22.1 & 54.4 & 9.5 & 14.1 & 63.9 & 23.6 \\
\hline 2 & 82.9 & 11.1 & 0.5 & 5.5 & 11.6 & 6.0 \\
\hline 3 & 88.6 & 5.6 & 0.4 & 5.5 & 6.0 & 5.9 \\
\hline 4 & 89.0 & 3.6 & 0.3 & 7.0 & 3.9 & 7.3 \\
\hline \multicolumn{7}{|c|}{ Cash $_{\text {ex ante }} \div$ Assets $_{\mathrm{t}-1}$ Quartile: } \\
\hline 1 & 56.1 & 26.3 & 5.5 & 12.1 & 31.8 & 17.6 \\
\hline 2 & 70.4 & 21.4 & 2.1 & 6.1 & 23.5 & 8.2 \\
\hline 3 & 75.4 & 17.0 & 1.6 & 6.0 & 18.6 & 7.6 \\
\hline 4 & 80.7 & 10.0 & 1.4 & 7.9 & 11.4 & 9.3 \\
\hline \multicolumn{7}{|c|}{$\mathrm{NCF}_{\mathrm{t}-1} \div$ Assets $_{\mathrm{t}-1}$ Quartile: } \\
\hline 1 (low) & 55.3 & 22.6 & 6.0 & 16.1 & 28.6 & 22.1 \\
\hline 2 & 70.4 & 20.7 & 2.2 & 6.7 & 22.9 & 8.9 \\
\hline 3 & 77.1 & 17.2 & 1.3 & 4.5 & 18.5 & 5.8 \\
\hline 4 (high) & 79.8 & 14.3 & 1.2 & 4.7 & 15.5 & 5.9 \\
\hline \multicolumn{7}{|c|}{$\mathrm{NCF}_{\mathrm{t}} \div$ Assets $_{\mathrm{t}-1}$ Quartile: } \\
\hline 1 (low) & 27.1 & 45.6 & 10.0 & 17.3 & 55.6 & 27.3 \\
\hline 2 & 70.8 & 22.3 & 0.4 & 6.5 & 22.7 & 6.9 \\
\hline 3 & 92.2 & 4.1 & 0.1 & 3.6 & 4.2 & 3.7 \\
\hline 4 (high) & 92.5 & 2.7 & 0.2 & 4.6 & 2.9 & 4.8 \\
\hline \multicolumn{7}{|c|}{$\mathrm{NCF}_{\mathrm{t}+1} \div$ Assets $_{\mathrm{t}-1}$ Quartile: } \\
\hline 1 (low) & 54.1 & 22.3 & 6.3 & 17.3 & 28.6 & 23.6 \\
\hline 2 & 73.4 & 19.1 & 1.5 & 6.0 & 20.6 & 7.5 \\
\hline 3 & 79.5 & 15.8 & 0.9 & 3.7 & 16.7 & 4.6 \\
\hline 4 (high) & 75.7 & 17.5 & 1.8 & 5.0 & 19.3 & 6.8 \\
\hline \multicolumn{7}{|c|}{$\mathrm{NCF}_{\mathrm{t}+2} \div$ Assets $_{\mathrm{t}-1}$ Quartile: } \\
\hline 1 (low) & 58.5 & 20.2 & 5.5 & 15.9 & 25.7 & 21.4 \\
\hline 2 & 75.0 & 17.7 & 1.7 & 5.7 & 19.4 & 7.4 \\
\hline 3 & 77.4 & 17.3 & 1.2 & 4.1 & 18.5 & 5.3 \\
\hline 4 (high) & 72.4 & 19.5 & 2.0 & 6.1 & 21.5 & 8.1 \\
\hline
\end{tabular}




\begin{tabular}{|c|c|c|c|c|c|c|}
\hline & $\begin{array}{c}\text { No security } \\
\text { issue }\end{array}$ & $\begin{array}{l}\text { Pure debt } \\
\text { issue }\end{array}$ & $\begin{array}{l}\text { Dual } \\
\text { issues }\end{array}$ & $\begin{array}{l}\text { Pure equity } \\
\text { issue }\end{array}$ & $\begin{array}{l}\text { All debt } \\
\text { issue }\end{array}$ & $\begin{array}{l}\text { All equity } \\
\text { issue }\end{array}$ \\
\hline \multicolumn{7}{|c|}{ OIBD $_{\mathrm{t}-1}$ Quartile: } \\
\hline 1 (low) & 67.4 & 13.4 & 3.9 & 15.3 & 17.3 & 19.2 \\
\hline 2 & 75.0 & 18.0 & 1.8 & 5.2 & 19.8 & 7.0 \\
\hline 3 & 70.6 & 22.2 & 2.3 & 5.0 & 24.5 & 7.3 \\
\hline 4 (high) & 69.6 & 21.1 & 2.8 & 6.5 & 23.9 & 9.3 \\
\hline \multicolumn{7}{|c|}{$\mathrm{ICF}_{\mathrm{t}-1} \div$ Assets $_{\mathrm{t}-2}$ Quartile: } \\
\hline 1 (low) & 67.4 & 13.8 & 3.8 & 15.1 & 17.6 & 18.9 \\
\hline 2 & 73.8 & 19.1 & 1.9 & 5.2 & 21.0 & 7.1 \\
\hline 3 & 71.6 & 21.3 & 2.2 & 4.9 & 23.5 & 7.1 \\
\hline 4 (high) & 69.8 & 20.5 & 2.8 & 6.9 & 23.3 & 9.7 \\
\hline \multicolumn{7}{|c|}{ Investments $_{\mathrm{t}} \div$ Assets $_{\mathrm{t}-1}$ Quartile: } \\
\hline 1 (low) & 84.2 & 7.8 & 0.8 & 7.2 & 8.6 & 8.0 \\
\hline 2 & 82.3 & 10.5 & 0.8 & 6.4 & 11.3 & 7.2 \\
\hline 3 & 74.7 & 17.2 & 1.1 & 7.0 & 18.3 & 8.1 \\
\hline 4 (high) & 41.4 & 39.3 & 8.0 & 11.4 & 47.3 & 19.4 \\
\hline \multicolumn{7}{|c|}{$\Delta \operatorname{Cash}_{t} \div$ Assets $_{\mathrm{t}-1}$ Quartile: } \\
\hline 1 (low) & 75.4 & 16.7 & 2.0 & 5.9 & 18.7 & 7.9 \\
\hline 2 & 73.2 & 20.8 & 1.7 & 4.3 & 22.5 & 6.0 \\
\hline 3 & 71.3 & 21.4 & 2.1 & 5.2 & 23.5 & 7.3 \\
\hline 4 (high) & 62.7 & 15.8 & 4.8 & 16.7 & 20.6 & 21.5 \\
\hline \multicolumn{7}{|c|}{$\Delta$ Non-Cash Assets $_{\mathrm{t}} \div$ Assets $_{\mathrm{t}-1}$ Quartile: $^{-}$} \\
\hline 1 (low) & 84.9 & 7.0 & 1.0 & 7.2 & 8.0 & 8.2 \\
\hline 2 & 84.7 & 9.2 & 0.6 & 5.5 & 9.8 & 6.1 \\
\hline 3 & 72.5 & 19.9 & 1.0 & 6.7 & 20.9 & 7.7 \\
\hline 4 (high) & 40.5 & 38.7 & 8.1 & 12.6 & 46.8 & 20.7 \\
\hline \multicolumn{7}{|c|}{ Tobin's $\mathrm{Q}_{\mathrm{t}-1}$ Quartile: } \\
\hline 1 (low) & 79.3 & 16.4 & 1.1 & 3.2 & 17.5 & 4.3 \\
\hline 2 & 72.0 & 20.4 & 2.1 & 5.4 & 22.5 & 7.5 \\
\hline 3 & 67.2 & 21.4 & 3.4 & 8.1 & 24.8 & 11.5 \\
\hline 4 (high) & 64.1 & 16.4 & 4.2 & 15.3 & 20.6 & 19.5 \\
\hline \multicolumn{7}{|c|}{ Stock Return $_{\mathrm{t}-1}$ Quartile: } \\
\hline 1 (low) & 72.8 & 16.2 & 2.4 & 8.6 & 18.6 & 11.0 \\
\hline 2 & 73.6 & 18.6 & 2.0 & 5.8 & 20.6 & 7.8 \\
\hline 3 & 72.0 & 19.5 & 2.4 & 6.1 & 21.9 & 8.5 \\
\hline 4 (high) & 64.2 & 20.4 & 4.0 & 11.5 & 24.4 & 15.5 \\
\hline \multicolumn{7}{|c|}{ Stock Return $_{\mathrm{t}+1, \mathrm{t}+3}$ Quartile: } \\
\hline 1 (low) & 60.0 & 21.3 & 4.9 & 13.8 & 26.2 & 18.7 \\
\hline 2 & 72.1 & 18.5 & 2.2 & 7.2 & 20.7 & 9.4 \\
\hline 3 & 75.5 & 17.6 & 1.8 & 5.1 & 19.4 & 6.9 \\
\hline 4 (high) & 75.0 & 17.4 & 1.8 & 5.8 & 19.2 & 7.6 \\
\hline
\end{tabular}


Table 5 Continued:

\begin{tabular}{|c|c|c|c|c|c|c|}
\hline & $\begin{array}{l}\text { No security } \\
\text { issue }\end{array}$ & $\begin{array}{l}\text { Pure debt } \\
\text { issue }\end{array}$ & $\begin{array}{l}\text { Dual } \\
\text { issues }\end{array}$ & $\begin{array}{l}\text { Pure equity } \\
\text { issue }\end{array}$ & $\begin{array}{l}\text { All debt } \\
\text { issue }\end{array}$ & $\begin{array}{l}\text { All equity } \\
\text { issue }\end{array}$ \\
\hline \multicolumn{7}{|l|}{ Term Spread $_{\mathrm{t}-1}$ Quartile: } \\
\hline 1 (low) & 71.3 & 18.2 & 2.6 & 8.0 & 20.8 & 10.6 \\
\hline 2 & 73.6 & 19.5 & 1.8 & 5.1 & 21.3 & 6.9 \\
\hline 3 & 65.5 & 22.4 & 3.7 & 8.4 & 26.1 & 12.1 \\
\hline 4 (high) & 70.8 & 17.4 & 2.7 & 9.0 & 20.1 & 11.7 \\
\hline \multicolumn{7}{|c|}{ Default Spread $_{\mathrm{t}-1}$ Quartile: } \\
\hline 1 (low) & 71.3 & 18.2 & 2.4 & 8.0 & 20.6 & 10.4 \\
\hline 2 & 68.5 & 20.1 & 3.0 & 8.4 & 23.1 & 11.4 \\
\hline 3 & 67.6 & 22.4 & 3.0 & 6.9 & 25.4 & 9.9 \\
\hline 4 (high) & 71.7 & 17.5 & 2.6 & 8.1 & 20.1 & 10.7 \\
\hline \multicolumn{7}{|l|}{$\operatorname{Ln}(\text { Sales })_{\mathrm{t}-1}$ Quartile: } \\
\hline 1 (low) & 63.2 & 16.0 & 4.5 & 16.2 & 20.5 & 20.7 \\
\hline 2 & 70.5 & 19.4 & 2.6 & 7.5 & 22.0 & 10.1 \\
\hline 3 & 72.2 & 20.5 & 2.1 & 5.2 & 22.6 & 7.3 \\
\hline 4 (high) & 76.6 & 18.8 & 1.4 & 3.2 & 20.2 & 4.6 \\
\hline \multicolumn{7}{|l|}{ Age $_{t}$ Quartile: } \\
\hline 1 (young) & 63.4 & 19.8 & 4.3 & 12.5 & 24.1 & 16.8 \\
\hline 2 & 68.7 & 18.9 & 3.1 & 9.3 & 22.0 & 12.4 \\
\hline 3 & 72.6 & 18.3 & 2.1 & 7.0 & 20.4 & 9.1 \\
\hline 4 (old) & 77.7 & 17.7 & 1.2 & 3.4 & 18.9 & 4.6 \\
\hline \multicolumn{7}{|l|}{ Leverage $_{t-1}$ Quartile: } \\
\hline 1 (low) & 77.1 & 12.4 & 1.6 & 8.8 & 14.0 & 10.4 \\
\hline 2 & 70.3 & 20.2 & 2.4 & 7.2 & 22.6 & 9.6 \\
\hline 3 & 68.6 & 21.6 & 2.8 & 7.0 & 24.4 & 9.8 \\
\hline 4 (high) & 66.6 & 20.5 & 3.9 & 9.0 & 24.4 & 12.9 \\
\hline \multicolumn{7}{|l|}{$\mathrm{R} \& \mathrm{D}_{\mathrm{t}-1}$ Group: } \\
\hline 0 (zero or missing) & 68.8 & 21.9 & 3.1 & 6.2 & 25.0 & 9.3 \\
\hline 1 (low) & 75.7 & 17.5 & 1.6 & 5.2 & 19.1 & 6.8 \\
\hline 2 (high) & 69.4 & 13.1 & 2.8 & 14.7 & 15.9 & 17.5 \\
\hline \multicolumn{7}{|c|}{ Industry Volatility ${ }_{\mathrm{t}-1}$ Quartile: } \\
\hline 1 (low) & 73.2 & 20.6 & 1.9 & 4.3 & 22.5 & 6.2 \\
\hline 2 & 70.8 & 19.5 & 2.7 & 7.0 & 22.2 & 9.7 \\
\hline 3 & 69.7 & 17.4 & 3.0 & 9.8 & 20.4 & 12.8 \\
\hline 4 (high) & 68.4 & 16.7 & 3.2 & 11.8 & 19.9 & 15.0 \\
\hline \multicolumn{7}{|l|}{ Dividend Payer $r_{t-1}$ : } \\
\hline 0 (Non-payer) & 66.3 & 18.2 & 3.6 & 11.9 & 21.8 & 15.5 \\
\hline 1 (Payer) & 76.1 & 19.3 & 1.4 & 3.1 & 20.7 & 4.5 \\
\hline
\end{tabular}


Table 6. Sample distribution by profitability, leverage, cash depletion, and securities issuance: Is there a pecking order?

This table reports the sample distribution by profitability, leverage, cash depletion, and securities issuance. Firm-years are then placed into one of four panels based on this $2 \times 2$ sort of profitability and leverage. Industry median leverage $t_{t-1}$ for a firm is the median Leverage $t_{t-1}$ of all firms in the same industry (using the two-digit SIC code). Ex post cash depletion is defined as Cash ex post $\leq 0$, where Cash ex post $=\operatorname{Cash}_{t}-\Delta \mathrm{D}_{\mathrm{t}}-\Delta \mathrm{E}_{\mathrm{t}} . \mathrm{N}$ denotes the number of firm-years. $\%$ denotes the percent of firm-years in a group. An equity issue in year $t$ is defined as consistent with the pecking order if the equity issuer is running out of cash at the end of year $t$ and has higher leverage than the industry median leverage or negative profitability or both. Firm-years consistent with the pecking order among equity issuers are in italics, representing $41.3 \%$ of all equity issues. A debt issue is defined as consistent with the pecking order if the debt issuer is running out of cash. By this definition, $76.1 \%$ of all debt issues are consistent with the pecking order. The total number of firm-years in this table is 116,326 rather than 116,488 because this table requires a non-missing value of $\mathrm{OIBD}_{\mathrm{t}-1}$. See the Appendix and Table 1 for additional variable definitions.

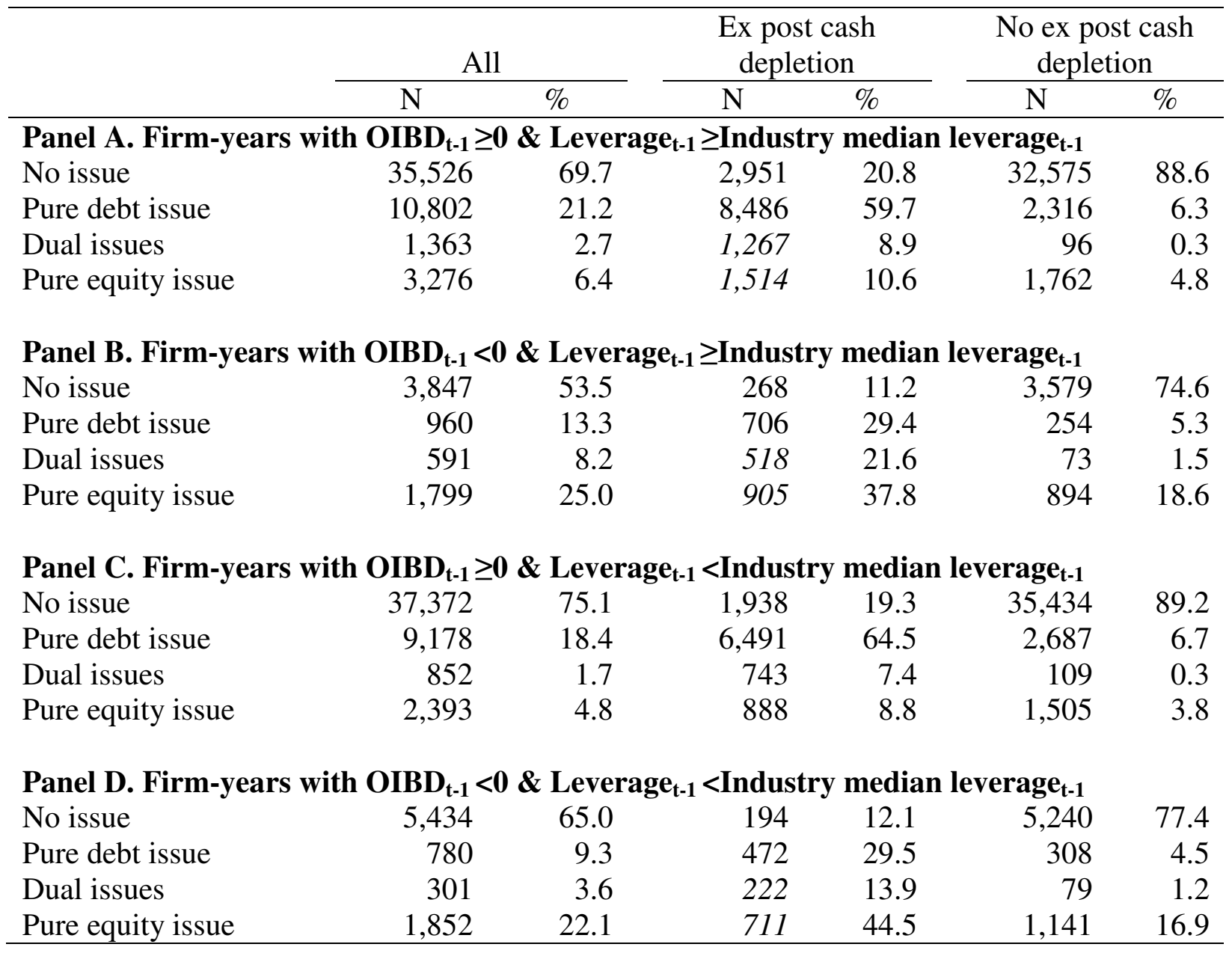




\section{Table 7. Multinomial logit for the issuance and choice of securities}

This table reports the results for the multinomial logit regressions for the decision to issue only debt, only equity, both debt and equity, or neither debt nor equity (the base case). A firm is defined to have a pure equity issue if $\left(\Delta \mathrm{E}_{\mathrm{t}} \div\right.$ Assets $_{\mathrm{t}-1} \geqslant 0.05$ and $\left.\Delta \mathrm{E}_{\mathrm{t}} \div \mathrm{ME}_{\mathrm{t}-1} \geqslant 0.03\right)$ and $\left(\Delta \mathrm{D}_{\mathrm{t}} \div\right.$ Assets $_{\mathrm{t}-1}<0.05$ or $\left.\Delta \mathrm{D}_{\mathrm{t}} \div \mathrm{ME}_{\mathrm{t}-1}<0.03\right)$. A firm is defined to have a pure debt issue if $\left(\Delta \mathrm{E}_{\mathrm{t}} \div\right.$ Assets $_{\mathrm{t}-1}<0.05$ or $\left.\Delta \mathrm{E}_{\mathrm{t}} \div \mathrm{ME}_{\mathrm{t}-1}<0.03\right)$ and $\left(\Delta \mathrm{D}_{\mathrm{t}} \div\right.$ Assets $_{\mathrm{t}-1} \geqslant 0.05$ and $\left.\Delta \mathrm{D}_{\mathrm{t}} \div \mathrm{ME}_{\mathrm{t}-1} \geqslant 0.03\right)$. A firm is defined to have dual issues of debt and equity if $\left(\Delta \mathrm{E}_{\mathrm{t}} \div\right.$ Assets $_{\mathrm{t}-1} \geqslant 0.05$ and $\Delta \mathrm{E}_{\mathrm{t}} \div \mathrm{ME}_{\mathrm{t}-1} \geqslant$ $0.03)$ and $\left(\Delta \mathrm{D}_{\mathrm{t}} \div\right.$ Assets $_{\mathrm{t}-1} \geqslant 0.05$ and $\left.\Delta \mathrm{D}_{\mathrm{t}} \div \mathrm{ME}_{\mathrm{t}-1} \geqslant 0.03\right)$. Assets $\mathrm{t}_{\mathrm{t}-1}$ and $\mathrm{ME}_{\mathrm{t}-1}$ denote the book value of assets and the market value of equity, respectively, at the end of fiscal year $\mathrm{t}-1$. Current Depletion Dummy equals one if $\mathrm{Cash}_{\mathrm{t}-1}+\mathrm{NCF}_{\mathrm{t}} \leqslant 0$ and zero otherwise. Near Depletion Dummy equals one if $\mathrm{Cash}_{\mathrm{t}-1}+\mathrm{NCF}_{\mathrm{t}}>0$ and $\mathrm{Cash}_{\mathrm{t}-1}+\mathrm{NCF}_{\mathrm{t}}+\mathrm{NCF}_{\mathrm{t}+1} \leqslant 0$, and equals zero otherwise. Remote Depletion Dummy equals one if $\mathrm{Cash}_{\mathrm{t}-1}+\mathrm{NCF}_{\mathrm{t}}>0, \mathrm{Cash}_{\mathrm{t}-1}+\mathrm{NCF}_{\mathrm{t}}+\mathrm{NCF}_{\mathrm{t}+1}>0$, and $\mathrm{Cash}_{\mathrm{t}-1}+\mathrm{NCF}_{\mathrm{t}}+\mathrm{NCF}_{\mathrm{t}+1}+\mathrm{NCF}_{\mathrm{t}+2} \leqslant 0$, and equals zero otherwise. Note that by definition, $\mathrm{Cash}_{\mathrm{t}-}$ ${ }_{1}+\mathrm{NCF}_{\mathrm{t}}=\mathrm{Cash}_{\mathrm{t}+1}-\Delta \mathrm{D}_{\mathrm{t}}-\Delta \mathrm{E}_{\mathrm{t}}, \mathrm{Cash}_{\mathrm{t}-1}+\mathrm{NCF}_{\mathrm{t}}+\mathrm{NCF}_{\mathrm{t}+1}=\mathrm{Cash}_{\mathrm{t}+1}-\Delta \mathrm{D}_{\mathrm{t}}-\Delta \mathrm{E}_{\mathrm{t}}-\Delta \mathrm{D}_{\mathrm{t}+1}-\Delta \mathrm{E}_{\mathrm{t}+1}$, and $\mathrm{Cash}_{\mathrm{t}-1}+\mathrm{NCF}_{\mathrm{t}}+\mathrm{NCF}_{\mathrm{t}+1}+\mathrm{NCF}_{\mathrm{t}+2}=\mathrm{Cash}_{\mathrm{t}+2}-\Delta \mathrm{D}_{\mathrm{t}}-\Delta \mathrm{E}_{\mathrm{t}}-\Delta \mathrm{D}_{\mathrm{t}+1}-\Delta \mathrm{E}_{\mathrm{t}+1}-\Delta \mathrm{D}_{\mathrm{t}+2}-\Delta \mathrm{E}_{\mathrm{t}+2}$. Ex ante measures of cash depletion are similarly defined. Current Depletion Dummy ex ante equals one if $\mathrm{Cash}_{\mathrm{t}-1}+\mathrm{NCF}_{\mathrm{t}-1} \leqslant 0$ and equals zero otherwise. Near Depletion Dummy ex ante equals one if $\mathrm{Cash}_{\mathrm{t}-1}+\mathrm{NCF}_{\mathrm{t}-1}>0$ and $\mathrm{Cash}_{\mathrm{t}-1}+2 \times \mathrm{NCF}_{\mathrm{t}-1} \leqslant 0$, and equals zero otherwise. Remote Depletion Dummy ex ante equals one if $\mathrm{Cash}_{\mathrm{t}-1}+\mathrm{NCF}_{\mathrm{t}-1}>0, \mathrm{Cash}_{\mathrm{t}-1}+2 \times \mathrm{NCF}_{\mathrm{t}-1}>0$, and $\mathrm{Cash}_{\mathrm{t}-1}+3 \times \mathrm{NCF}_{\mathrm{t}-1} \leqslant$ 0 , and equals zero otherwise. Returns are measured as decimals (e.g., a $20 \%$ return is measured as 0.20) and spreads are measured as annual percentages. Panel A reports the coefficients and zstatistics, with the base category consisting of firm-years with no security issues. Panel B reports the economic effects, with Regression (1) using an ex post measure, and Regression (2) using an ex ante measure. To compute the economic effect of an independent variable on a pure equity issue, for example, we first add one standard deviation of the variable's sample values to its actual value for each observation in our sample, without changing the actual values of other independent variables, and compute the predicted average likelihood of a pure equity issue for all observations using the regressions coefficients. We also subtract its actual value by one standard deviation, without changing the actual values of other variables, and compute the predicted average likelihood of a pure equity issue. We then compute the change in the predicted average likelihood as the economic effect of this variable on a pure equity issue. For brevity, Panel B only reports the changes in the predicted average likelihoods but not the starting and ending values. For example, the economic effect of Current Depletion Dummy is 63.5\% (reported in Panel B), which is the difference between the predicted average likelihoods of $69.8 \%$ and $6.3 \%$ (not reported in Panel B) when the variable equals one and zero, respectively, using the actual values of other independent variables. In the last two columns of Panel B, the subtotal economic effects are reported. For example, the subtotal economic effect of Tobin's $\mathrm{Q}_{\mathrm{t}-1}$ on all debt issues is the sum of the economic effects of Tobin's $\mathrm{Q}_{\mathrm{t}-1}$ on pure debt issues and dual issues of debt and equity. See the Appendix for other variable definitions. Z-statistics are in parentheses, calculated using robust standard errors corrected for heteroskedasticity and clustering at the company level. $* * *, * *$, and $*$ indicates significance at the $1 \%, 5 \%$, and $10 \%$ level. 
Panel A: Coefficients and z-statistics

\begin{tabular}{|c|c|c|c|c|c|c|}
\hline \multirow[b]{2}{*}{ VARIABLES } & \multicolumn{3}{|c|}{ (1) Ex post cash need } & \multicolumn{3}{|c|}{ (2) Ex ante cash need } \\
\hline & $\begin{array}{l}\text { Pure debt } \\
\text { issue }\end{array}$ & $\begin{array}{l}\text { Dual } \\
\text { issues }\end{array}$ & $\begin{array}{l}\text { Pure } \\
\text { equity } \\
\text { issue }\end{array}$ & $\begin{array}{l}\text { Pure debt } \\
\text { issue }\end{array}$ & $\begin{array}{l}\text { Dual } \\
\text { issues }\end{array}$ & $\begin{array}{l}\text { Pure } \\
\text { equity } \\
\text { issue }\end{array}$ \\
\hline \multirow[t]{2}{*}{ Current Depletion Dummy } & $4.09 * * *$ & $5.87 * * *$ & $2.85 * * *$ & & & \\
\hline & $(133.02)$ & $(45.81)$ & $(73.95)$ & & & \\
\hline \multirow[t]{2}{*}{ Near Depletion Dummy } & $1.22 * * *$ & $2.53 * * *$ & $1.31 * * *$ & & & \\
\hline & $(34.58)$ & $(17.34)$ & $(32.54)$ & & & \\
\hline \multirow[t]{2}{*}{ Remote Depletion Dummy } & $0.56 * * *$ & $1.58 * * *$ & $0.69 * * *$ & & & \\
\hline & $(12.00)$ & $(8.40)$ & $(13.68)$ & & & \\
\hline \multirow{2}{*}{ Current Depletion Dummy ex ante } & & & & $0.79 * * *$ & $1.46 * * *$ & $0.89 * * *$ \\
\hline & & & & $(39.81)$ & (29.74) & $(30.27)$ \\
\hline \multirow[t]{2}{*}{ Near Depletion Dummy ex ante } & & & & $0.45 * * *$ & $0.96 * * *$ & $0.75 * * *$ \\
\hline & & & & (15.09) & (14.26) & $(18.71)$ \\
\hline \multirow{2}{*}{ Remote Depletion Dummy ex ante } & & & & $0.21 * * *$ & $0.42 * * *$ & $0.47 * * *$ \\
\hline & & & & $(5.26)$ & $(4.06)$ & $(8.99)$ \\
\hline \multirow[t]{2}{*}{ Tobin's $\mathrm{Q}_{\mathrm{t}-1}$} & $-0.09 * * *$ & -0.02 & $0.09 * * *$ & $-0.05 * * *$ & $0.04 * *$ & $0.12 * * *$ \\
\hline & $(-6.82)$ & $(-0.74)$ & $(8.18)$ & $(-5.39)$ & $(2.39)$ & $(13.11)$ \\
\hline \multirow[t]{2}{*}{ Return $_{t-1}$} & $0.07 * * *$ & $0.20 * * *$ & $0.14 * * *$ & $0.18 * * *$ & $0.27 * * *$ & $0.21 * * *$ \\
\hline & $(2.97)$ & $(2.77)$ & $(5.65)$ & (11.64) & $(5.90)$ & (9.90) \\
\hline \multirow{2}{*}{$\operatorname{Return}_{t+1, t+3}$} & -0.00 & $-0.10 * * *$ & $-0.10 * * *$ & $-0.06 * * *$ & $-0.20 * * *$ & $-0.15 * * *$ \\
\hline & $(-0.70)$ & $(-4.20)$ & $(-7.81)$ & $(-8.11)$ & $(-6.95)$ & $(-10.82)$ \\
\hline \multirow[t]{2}{*}{ Term Spread $_{\mathrm{t}-1}(\%)$} & 0.03 & $0.15 * * *$ & 0.05 & 0.01 & $0.14 * * *$ & 0.03 \\
\hline & $(1.33)$ & (3.03) & $(1.52)$ & $(0.47)$ & (3.29) & (1.12) \\
\hline \multirow[t]{2}{*}{ Default Spread $_{\mathrm{t}-1}(\%)$} & $-0.10 * *$ & $0.35 * * *$ & $0.35 * * *$ & $-0.18 * * *$ & $0.18 * *$ & $0.28 * * *$ \\
\hline & $(-2.21)$ & (3.79) & $(8.01)$ & $(-5.38)$ & (2.33) & (7.11) \\
\hline \multirow{2}{*}{$\operatorname{Ln}(\text { Sales })_{\mathrm{t}-1}$} & $0.04 * * *$ & $-0.12 * * *$ & $-0.18 * * *$ & -0.00 & $-0.17 * * *$ & $-0.22 * * *$ \\
\hline & $(4.20)$ & $(-6.81)$ & $(-18.62)$ & $(-0.63)$ & $(-12.67)$ & $(-24.16)$ \\
\hline \multirow[t]{2}{*}{$\operatorname{Ln}(\text { Age })_{t}$} & $-0.13 * * *$ & $-0.39 * * *$ & $-0.25 * * *$ & $-0.16 * * *$ & $-0.40 * * *$ & $-0.25 * * *$ \\
\hline & $(-7.55)$ & $(-11.24)$ & $(-11.60)$ & $(-13.76)$ & $(-13.48)$ & $(-12.60)$ \\
\hline \multirow[t]{2}{*}{ Leverage $_{t-1}$} & -0.07 & $1.16 * * *$ & $0.83 * * *$ & $0.50 * * *$ & $1.56 * * *$ & $1.10 * * *$ \\
\hline & $(-1.22)$ & $(11.86)$ & (13.30) & $(11.27)$ & $(20.21)$ & (19.78) \\
\hline \multirow[t]{2}{*}{$R \& D_{t-1}$} & -0.18 & $2.30 * * *$ & $2.76 * * *$ & $-1.62 * * *$ & $1.21 * * *$ & $2.30 * * *$ \\
\hline & $(-0.87)$ & $(8.43)$ & (18.88) & $(-8.73)$ & $(5.18)$ & (18.35) \\
\hline \multirow[t]{2}{*}{ Industry Volatility $\mathrm{t}_{\mathrm{t}-1}$} & $0.51 * * *$ & $1.35 * * *$ & $1.03 * * *$ & $-0.55 * * *$ & -0.16 & $0.42 * * *$ \\
\hline & (3.67) & $(4.84)$ & $(6.42)$ & $(-5.42)$ & $(-0.71)$ & $(2.97)$ \\
\hline \multirow[t]{2}{*}{ Dividend Payer $_{\mathrm{t}-1}$} & $-0.15 * * *$ & $-0.40 * * *$ & $-0.52 * * *$ & -0.03 & $-0.24 * * *$ & $-0.46 * * *$ \\
\hline & $(-4.69)$ & $(-5.80)$ & $(-12.15)$ & $(-1.34)$ & $(-4.12)$ & $(-11.63)$ \\
\hline \multirow[t]{2}{*}{ Constant } & $-2.77 * * *$ & $-6.77 * * *$ & $-2.91 * * *$ & $-1.42 * * *$ & $-3.82 * * *$ & $-2.27 * * *$ \\
\hline & $(-23.12)$ & $(-22.94)$ & $(-18.69)$ & $(-15.51)$ & $(-16.47)$ & $(-15.88)$ \\
\hline Industry dummies & Yes & & & Yes & & \\
\hline Year dummies & Yes & & & Yes & & \\
\hline Observations & 102,773 & & & 116,488 & & \\
\hline Pseudo $\mathrm{R}^{2}(\%)$ & 32.90 & & & 10.51 & & \\
\hline
\end{tabular}


Panel B. Economic effects (\%) of a 2 standard dev. change in the explanatory variable

\begin{tabular}{|c|c|c|c|c|c|c|}
\hline VARIABLES & $\begin{array}{c}\text { No } \\
\text { security } \\
\text { issue }\end{array}$ & $\begin{array}{l}\text { Pure } \\
\text { debt } \\
\text { issue }\end{array}$ & $\begin{array}{c}\text { Dual } \\
\text { issues }\end{array}$ & $\begin{array}{c}\text { Pure } \\
\text { equity } \\
\text { issue } \\
\end{array}$ & $\begin{array}{c}\text { All } \\
\text { debt } \\
\text { issues } \\
\end{array}$ & $\begin{array}{c}\text { All } \\
\text { equity } \\
\text { issues } \\
\end{array}$ \\
\hline \multicolumn{7}{|l|}{ (ex post) Regression (1): } \\
\hline Current Depletion Dummy & -70.4 & 52.0 & 11.5 & 6.9 & 63.5 & 18.4 \\
\hline Near Depletion Dummy & -16.3 & 5.6 & 5.6 & 5.0 & 11.2 & 10.6 \\
\hline Remote Depletion Dummy & -7.9 & 1.7 & 3.8 & 2.4 & 5.5 & 6.2 \\
\hline Tobin's $\mathrm{Q}_{\mathrm{t}-1}$ & 0.8 & -2.8 & 0.1 & 2.0 & -2.7 & 2.1 \\
\hline Return $_{\mathrm{t}-1}$ & -2.3 & 0.4 & 0.6 & 1.3 & 1.0 & 1.9 \\
\hline $\operatorname{Return}_{\mathrm{t}+1, \mathrm{t}+3}$ & 2.0 & 1.1 & -0.7 & -2.3 & 0.4 & -3.0 \\
\hline $\operatorname{Term~Spread}_{\mathrm{t}-1}(\%)$ & -1.2 & 0.1 & 0.7 & 0.4 & 0.8 & 1.1 \\
\hline Default Spread $_{\mathrm{t}-1}(\%)$ & -0.9 & -2.1 & 0.8 & 2.2 & -1.3 & 3.0 \\
\hline $\operatorname{Ln}(\text { Sales })_{t-1}$ & 2.1 & 3.6 & -0.9 & -4.7 & 2.7 & -5.6 \\
\hline $\operatorname{Ln}(\text { Age })_{t}$ & 3.5 & -0.6 & -1.0 & -1.9 & -1.6 & -2.9 \\
\hline Leverage $_{t-1}$ & -1.5 & -1.7 & 1.1 & 2.1 & -0.6 & 3.2 \\
\hline $\mathrm{R} \& \mathrm{D}_{\mathrm{t}-1}$ & -1.9 & -1.7 & 0.7 & 2.9 & -1.0 & 3.6 \\
\hline Industry Volatility $_{\mathrm{t}-1}$ & -2.5 & 0.5 & 0.6 & 1.4 & 1.1 & 2.0 \\
\hline Dividend Payer $\mathrm{t}_{\mathrm{t}-1}$ & 3.2 & -0.1 & -0.5 & -2.6 & -0.6 & -3.1 \\
\hline \multicolumn{7}{|l|}{ (ex ante) Regression (2): } \\
\hline Current Depletion Dummy ex ante & -17.6 & 10.2 & 3.2 & 4.3 & 13.4 & 7.5 \\
\hline Near Depletion Dummy ex ante & -11.4 & 4.9 & 2.3 & 4.3 & 7.2 & 6.6 \\
\hline Remote Depletion Dummy ex ante & -5.8 & 2.2 & 0.8 & 2.8 & 3.0 & 3.6 \\
\hline Tobin's $\mathrm{Q}_{\mathrm{t}-1}$ & 0.1 & -2.5 & 0.2 & 2.2 & -2.3 & 2.4 \\
\hline Return $_{t-1}$ & -7.5 & 4.5 & 1.0 & 2.0 & 5.5 & 3.0 \\
\hline Return $_{t+1, t+3}$ & 7.0 & -2.2 & -1.6 & -3.1 & -3.8 & -4.7 \\
\hline Term Spread $_{\mathrm{t}-1}(\%)$ & -1.1 & 0.0 & 0.8 & 0.3 & 0.8 & 1.1 \\
\hline Default Spread $_{\mathrm{t}-1}(\%)$ & 0.8 & -3.2 & 0.5 & 2.0 & -2.7 & 2.5 \\
\hline $\operatorname{Ln}(\text { Sales })_{t-1}$ & 5.3 & 1.4 & -1.4 & -5.3 & 0.0 & -6.7 \\
\hline $\operatorname{Ln}(\text { Age })_{t}$ & 6.3 & -2.9 & -1.4 & -2.0 & -4.3 & -3.4 \\
\hline Leverage $_{t-1}$ & -6.3 & 2.2 & 1.5 & 2.6 & 3.7 & 4.1 \\
\hline $\mathrm{R} \& \mathrm{D}_{\mathrm{t}-1}$ & 1.5 & -5.0 & 0.5 & 3.0 & -4.5 & 3.5 \\
\hline Industry Volatility $_{\mathrm{t}-1}$ & 1.6 & -2.6 & -0.1 & 1.1 & -2.7 & 1.0 \\
\hline Dividend Payer $_{\mathrm{t}-1}$ & 2.7 & 0.3 & -0.4 & -2.6 & -0.1 & -3.0 \\
\hline
\end{tabular}


Table 8. Cash needs, cash changes, and cash sources

This table reports the results for the firm fixed effects regressions for cash changes. In Panel A, the dependent variable is $\Delta \operatorname{Cash}_{t} \times 100 \div$ Assets $_{t-1}$. The explanatory variables measure firm fundamentals. The dependent variable in Panel B is Res $\Delta$ Cash $_{t} \times 100 \div$ Assets $_{t-1}$, or the residuals from the regressions in Panel A. The explanatory variables measure market conditions. In regressions (1), (5), and (9) of Panel C, the dependent variable is $\Delta$ Cash $_{t} \div$ Asset $_{t-1}$. In regressions (2), (6), and (10) of Panel C, the dependent variable is Fitted $\Delta$ Cash $_{t} \times 100 \div$ Assets $_{t-1}$, or the fitted values from the regressions in Panel A (the $\Delta \mathrm{Cash}_{t}$ due to fundamentals). In regressions (3), (7), and (11), the dependent variable is Fitted Res $\Delta$ Cash $_{t} \times 100 \div$ Asset $_{t-1}$, or the fitted values from the regressions in Panel B (the $\Delta C_{a s h_{t}}$ due to market conditions). In regressions (4), (8), and (12), the dependent variable is Res Res $\Delta \operatorname{Cash}_{t} \times 100 \div$ Assets $_{t-1}$, or the residuals from the regressions in Panel B (the unexplained $\Delta \operatorname{Cash}_{t}$ ). A firm is defined to have an equity issue in year $\mathrm{t}$ if $\Delta \mathrm{E}_{\mathrm{t}} \div$ Assets $_{\mathrm{t}-1} \geqslant 0.05$ and $\Delta \mathrm{E}_{\mathrm{t}} \div \mathrm{ME}_{\mathrm{t}-1} \geqslant 0.03$. A firm is defined to have a debt issue in year $\mathrm{t}$ if $\Delta \mathrm{D}_{\mathrm{t}} \div$ Assets $_{\mathrm{t}-1} \geqslant 0.05$ and $\Delta \mathrm{D}_{\mathrm{t}} \div \mathrm{ME}_{\mathrm{t}-1} \geqslant 0.03$. Assets $\mathrm{t}_{\mathrm{t}-1}$ and $\mathrm{ME}_{\mathrm{t}-1}$ denote the book value of assets and the market value of equity, respectively, at the end of fiscal year $\mathrm{t}-1$. Assets $\mathrm{t}_{\mathrm{t}-1}$ in rows (5a) and (5b) of Panel $\mathrm{C}$ is expressed in purchasing power at the end of 2010. Returns are measured as decimals (e.g., a $20 \%$ return is measured as 0.20) and spreads are measured as annual percentages. See the Appendix for other variable definitions. $\mathrm{N}$ denotes the number of observations. Adjusted within $\mathrm{R}^{2}$ s for the firm fixed effects regressions are reported. T-statistics are calculated using robust standard errors corrected for heteroskedasticity and clustering at the company level. ***, **, and * indicates significance at the $1 \%, 5 \%$, and $10 \%$ level.

Panel A: Dependent variable is $\Delta \operatorname{Cash}_{t} \times 100 \div$ Assets $_{t-1}$

\begin{tabular}{|c|c|c|c|c|c|c|}
\hline & \multicolumn{2}{|c|}{ (1) Full Sample } & \multicolumn{2}{|c|}{ (2) Equity Issue Sample } & \multicolumn{2}{|c|}{ (3) Debt Issue Sample } \\
\hline Variables & Coeff. & t-Stat. & Coeff. & t-Stat. & Coeff. & t-Stat. \\
\hline Cash $_{\mathrm{t}-1} \div$ Assets $_{\mathrm{t}-1}$ & $-44.3 * * *$ & -43.1 & $-42.3 * * *$ & -10.4 & $-52.6 * * *$ & -20.3 \\
\hline$\Delta$ Non-Cash Assets $_{t} \div$ Assets $_{\mathrm{t}-1}$ & $2.1 * * *$ & 6.7 & $5.1 * * *$ & 5.4 & $1.9 * * *$ & 4.6 \\
\hline $\mathrm{NCF}_{\mathrm{t}+1} \div$ Assets $_{\mathrm{t}-1}$ & $-13.2 * * *$ & -26.0 & $-18.4 * * *$ & -13.8 & $-9.5 * * *$ & -11.8 \\
\hline $\mathrm{NCF}_{\mathrm{t}+2} \div$ Assets $_{\mathrm{t}-1}$ & $-5.5 * * *$ & -14.8 & $-7.6 * * *$ & -7.6 & $-3.1 * * *$ & -5.2 \\
\hline $\operatorname{Ln}(\text { Assets })_{\mathrm{t}-1}$ & $-5.5 * * *$ & -21.3 & $-7.9 * * *$ & -7.7 & $-2.9 * * *$ & -5.5 \\
\hline $\operatorname{Ln}(\text { Sales })_{t-1}$ & $3.0 * * *$ & 11.8 & $4.4^{* * *}$ & 5.5 & $1.7 * * *$ & 3.4 \\
\hline $\operatorname{Ln}(\text { Age })_{t}$ & 0.2 & 1.5 & 0.2 & 0.2 & 0.4 & 1.5 \\
\hline Leverage $_{t-1}$ & -0.4 & -0.7 & $-4.6 * *$ & -2.0 & 0.7 & 0.7 \\
\hline $\mathrm{R} \& \mathrm{D}_{\mathrm{t}-1}$ & $27.9 * * *$ & 10.7 & $29.2 * * *$ & 5.0 & $21.7 * * *$ & 3.1 \\
\hline Industry Volatility $_{\mathrm{t}-1}$ & 1.5 & 1.6 & -7.1 & -1.0 & $3.5^{*}$ & 1.9 \\
\hline Dividend Payer $_{\mathrm{t}-1}$ & -0.3 & -1.6 & -0.6 & -0.4 & 0.0 & 0.0 \\
\hline Constant & $21.9 * * *$ & 22.7 & $36.4 * * *$ & 7.1 & $11.1 * * *$ & 6.2 \\
\hline Year Dummies & Yes & & Yes & & Yes & \\
\hline $\mathrm{N}$ & 102,773 & & 10,792 & & 21,842 & \\
\hline Adjusted Within $\mathrm{R}^{2}(\%)$ & 17.9 & & 20.1 & & 17.1 & \\
\hline
\end{tabular}


Panel B: Dependent variable is Res $\Delta \operatorname{Cash}_{t} \times 100 \div$ Assets $_{t-1}$, the residuals from the Panel A regressions

\begin{tabular}{|c|c|c|c|c|c|c|}
\hline & \multicolumn{2}{|c|}{ (1) Full Sample } & \multicolumn{2}{|c|}{ (2) Equity Issue Sample } & \multicolumn{2}{|c|}{ (3) Debt Issue Sample } \\
\hline Variables & Coeff. & t-Stat. & Coeff. & t-Stat. & Coeff. & t-Stat. \\
\hline Tobin's $\mathrm{Q}_{\mathrm{t}-1}$ & $2.3 * * *$ & $(19.4)$ & $4.2 * * *$ & $(10.3)$ & $2.2 * * *$ & $(6.9)$ \\
\hline Return $_{\mathrm{t}-1}$ & $0.3 * * *$ & (4.6) & 0.2 & $(0.6)$ & 0.3 & (1.4) \\
\hline $\operatorname{Return}_{\mathrm{t}+1, t+3}$ & $-0.2 * *$ & $(-2.5)$ & $-1.7 * * *$ & $(-7.7)$ & $-0.3 * * *$ & $(-3.2)$ \\
\hline $\operatorname{Term~Spread~}_{\mathrm{t}-1}(\%)$ & 0.1 & (1.4) & 0.4 & (1.4) & 0.0 & $(0.3)$ \\
\hline Default Spread $_{t-1}(\%)$ & $0.9 * * *$ & (9.9) & $2.0 * * *$ & (3.2) & $0.6^{* *}$ & $(2.4)$ \\
\hline Constant & $-4.9 * * *$ & $(-19.4)$ & $-13.0 * * *$ & $(-10.3)$ & $-4.2 * * *$ & $(-6.8)$ \\
\hline $\mathrm{N}$ & 102,773 & & 10,792 & & 21,842 & \\
\hline Adjusted Within $\mathrm{R}^{2}(\%)$ & 3.4 & & 7.2 & & 2.2 & \\
\hline
\end{tabular}

Panel C: Sources of the cash change

\begin{tabular}{|c|c|c|c|c|c|c|c|c|c|c|}
\hline \multirow{2}{*}{$\begin{array}{l}\text { Dependent } \\
\text { variable }\end{array}$} & \multicolumn{2}{|c|}{$\begin{array}{c}\Delta \mathrm{E}_{\mathrm{t}} \\
\div \text { Assets }_{\mathrm{t}-1}\end{array}$} & \multicolumn{2}{|c|}{$\begin{array}{c}\Delta \mathrm{D}_{\mathrm{t}} \\
\div \text { Assets }_{\mathrm{t}-1}\end{array}$} & \multicolumn{2}{|c|}{$\begin{array}{c}\mathrm{ICF}_{\mathrm{t}} \\
\div \text { Assets }_{\mathrm{t}-1}\end{array}$} & \multicolumn{2}{|c|}{ Constant } & \multirow[b]{2}{*}{$\mathrm{N}$} & \multirow{2}{*}{$\begin{array}{c}\text { Within } \\
\text { Adj. } \\
\mathrm{R}^{2}(\%)\end{array}$} \\
\hline & Coeff. & t-Stat & Coeff. & t-Stat & Coeff. & t-Stat & Coeff. & t-Stat & & \\
\hline \multicolumn{11}{|l|}{ Full Sample } \\
\hline (1) $\Delta$ Cash $_{t} \times 100 \div$ Assets $_{t-1}$ & $59.8 * * *$ & 73.7 & $10.8 * * *$ & 14.1 & $26.8 * * *$ & 32.4 & $-3.0 * * *$ & -33.0 & 102,773 & 39.7 \\
\hline (2) Fitted $\triangle C_{a s h}$ & $13.6 * * *$ & 50.1 & $4.9 * * *$ & 19.5 & $5.6 * * *$ & 14.0 & $0.7 * * *$ & 18.3 & 102,773 & 12.1 \\
\hline (3) Fitted Res $\Delta \mathrm{Cash}_{t}$ & $4.2 * * *$ & 33.3 & $1.9 * * *$ & 19.7 & $4.3 * * *$ & 21.5 & $-0.6^{* * *}$ & -32.4 & 102,773 & 10.7 \\
\hline (4) Unexplained $\Delta C a s h_{t}$ & $41.9 * * *$ & 52.4 & $4.0 * * *$ & 5.7 & $16.9 * * *$ & 18.9 & $-3.1 * * *$ & -32.2 & 102,773 & 23.8 \\
\hline \multicolumn{11}{|l|}{ Equity Issue Sample } \\
\hline (5) $\Delta$ Cash $_{t} \times 100 \div$ Assets $_{t-1}$ & $65.4 * * *$ & 48.7 & $10.1 * * *$ & 5.0 & $32.2 * * *$ & 15.7 & $-9.5^{* * *}$ & -19.0 & 10,792 & 53.7 \\
\hline$(5 \mathrm{a})\left(\right.$ Assets $\left._{t-1}>\$ 200 \mathrm{~mm}\right)$ & $40.6 * * *$ & 8.5 & $13.3 * * *$ & 4.4 & $15.7 * *$ & 2.6 & $-2.4 * *$ & -2.3 & 3,947 & 24.9 \\
\hline$(5 \mathrm{~b})\left(\operatorname{Assets}_{t-1} \leq \$ 200 \mathrm{~mm}\right)$ & $69.3 * * *$ & 46.3 & $12.2 * * *$ & 4.3 & $37.5 * * *$ & 16.5 & $-11.4 * * *$ & -16.4 & 6,845 & 58.0 \\
\hline (6) Fitted $\Delta$ Cash $_{t}$ & $18.0 * * *$ & 28.2 & $9.3 * * *$ & 10.3 & $6.4 * * *$ & 5.2 & $7.9 * * *$ & 34.1 & 10,792 & 21.7 \\
\hline (7) Fitted Res $\Delta$ Cash $_{t}$ & $9.1 * * *$ & 23.0 & $2.5 * * *$ & 5.4 & 0.8 & 1.1 & $-3.4 * * *$ & -23.6 & 10,792 & 17.8 \\
\hline (8) Unexplained $\Delta C a s h_{t}$ & $38.2 * * *$ & 27.1 & -1.7 & -0.9 & $25.0 * * *$ & 10.7 & $-14.0 * * *$ & -27.0 & 10,792 & 25.5 \\
\hline \multicolumn{11}{|l|}{ Debt Issue Sample } \\
\hline (9) $\Delta$ Cash $_{t} \times 100 \div$ Assets $_{t-1}$ & $29.6 * * *$ & 13.8 & $14.1 * * *$ & 12.2 & $12.5 * * *$ & 6.5 & $-2.5^{* * *}$ & -8.5 & 21,842 & 16.5 \\
\hline (10) Fitted $\Delta C a s h_{t}$ & $8.8 * * *$ & 13.8 & $0.8 * *$ & 2.0 & $5.8 * * *$ & 8.1 & $1.5 * * *$ & 15.0 & 21,842 & 6.3 \\
\hline (11) Fitted Res $\Delta C a s h_{t}$ & $1.9 * * *$ & 7.7 & $2.3 * * *$ & 16.4 & $1.8 * * *$ & 6.3 & $-0.7 * * *$ & -18.8 & 21,842 & 10.5 \\
\hline (12) Unexplained $\Delta \operatorname{Cash}_{t}$ & $18.8 * * *$ & 9.6 & $11.0 * * *$ & 9.9 & $4.8 * *$ & 2.6 & $-3.2 * * *$ & -11.7 & 21,842 & 9.0 \\
\hline
\end{tabular}




\section{Table 9: Mulitinomial logit for the debt vs. equity choice, conditional on issuing, and conditional on issuing and running out of cash}

This table reports the results for the multinomial logit regressions for the decision to issue only debt, only equity, or both debt and equity. A firm is defined to have a pure equity issue if $\left(\Delta \mathrm{E}_{\mathrm{t}} \div\right.$ Assets $_{\mathrm{t}-1} \geqslant 0.05$ and $\left.\Delta \mathrm{E}_{\mathrm{t}} \div \mathrm{ME}_{\mathrm{t}-1} \geqslant 0.03\right)$ and $\left(\Delta \mathrm{D}_{\mathrm{t}} \div\right.$ Assets $_{\mathrm{t}-1}<0.05$ or $\left.\Delta \mathrm{D}_{\mathrm{t}} \div \mathrm{ME}_{\mathrm{t}-1}<0.03\right)$. $\mathrm{A}$ firm is defined to have a pure debt issue if $\left(\Delta \mathrm{E}_{\mathrm{t}} \div\right.$ Assets $_{\mathrm{t}-1}<0.05$ or $\left.\Delta \mathrm{E}_{\mathrm{t}} \div \mathrm{ME}_{\mathrm{t}-1}<0.03\right)$ and $\left(\Delta \mathrm{D}_{\mathrm{t}}\right.$ $\div$ Assets $_{\mathrm{t}-1} \geqslant 0.05$ and $\left.\Delta \mathrm{D}_{\mathrm{t}} \div \mathrm{ME}_{\mathrm{t}-1} \geqslant 0.03\right)$. A firm is defined to have dual issues of debt and equity if $\left(\Delta \mathrm{E}_{\mathrm{t}} \div\right.$ Assets $_{\mathrm{t}-1} \geqslant 0.05$ and $\left.\Delta \mathrm{E}_{\mathrm{t}} \div \mathrm{ME}_{\mathrm{t}-1} \geqslant 0.03\right)$ and $\left(\Delta \mathrm{D}_{\mathrm{t}} \div\right.$ Assets $_{\mathrm{t}-1} \geqslant 0.05$ and $\Delta \mathrm{D}_{\mathrm{t}} \div \mathrm{ME}_{\mathrm{t}-1} \geqslant$ 0.03 . Assets $\mathrm{t}_{\mathrm{t}-1}$ and $\mathrm{ME}_{\mathrm{t}-1}$ denote the book value of assets and the market value of equity, respectively, at the end of fiscal year t-1. Regression (1) uses the subsample of firms that issue a security, regression (2) uses the subsample of security issuers that are running out of cash using an ex post measure (Cash ex post $\leqslant 0$ ), and regression (3) uses the subsample of security issuers that are running out of cash using an ex ante measure (Cash ex ante $\leqslant 0)$. Returns are measured as decimals (e.g., a $20 \%$ return is measured as 0.20) and spreads are measured as annual percentages. Panel A reports the coefficients and z-statistics, with the base category consisting of firm-years with pure debt issues. Panel B reports the economic effects (see Table 7 for details). In the last two columns of Panel B, the subtotal economic effects are reported. For example, the subtotal economic effect of Tobin's $\mathrm{Q}_{\mathrm{t}-1}$ on all debt issues is the sum of the economic effects of Tobin's $\mathrm{Q}_{\mathrm{t}-1}$ on pure debt issues and dual issues of debt and equity. See the Appendix for other variable definitions. Z-statistics are in parentheses, calculated using robust standard errors corrected for heteroskedasticity and clustering at the company level.

Pseudo $\mathrm{R}^{2}$ w/o year dummy variables is the pseudo $\mathrm{R}^{2}$ of the multinomial logit regression for which the independent variables include the timing, lifecycle, precautionary saving, and tradeoff proxies and the industry dummy variables but exclude (w/o stands for without) the year variables. Pseudo $\mathrm{R}^{2}$ w/o industry dummy variables is the pseudo $\mathrm{R}^{2}$ of the multinomial logit regression for which the independent variables include the timing, lifecycle, precautionary saving, and tradeoff proxies and the year dummy variables but exclude the industry dummy variables. Pseudo $\mathrm{R}^{2}$ w/o timing is the pseudo $\mathrm{R}^{2}$ of the multinomial logit regression that excludes Tobin's $\mathrm{Q}_{\mathrm{t}-1}$, $\operatorname{Return}_{\mathrm{t}-1}$, Return $_{\mathrm{t}+1, \mathrm{t}+3}$, Term $\operatorname{Spread}_{\mathrm{t}-1}$, and Default $\operatorname{Spread}_{\mathrm{t}-1}$ from the set of independent variables. Alternatively stated, pseudo $\mathrm{R}^{2}$ w/o timing is the pseudo $\mathrm{R}^{2}$ of the multinomial logit regression for which the independent variables include the lifecycle, precautionary saving, and tradeoff proxies, as well as the year and industry dummy variables but exclude the proxies for market conditions. Pseudo $\mathrm{R}^{2}$ w/o lifecycle is the pseudo $\mathrm{R}^{2}$ of the multinomial logit regression that excludes $\operatorname{Ln}(\text { Sales })_{\mathrm{t}-1}$ and $\operatorname{Ln}(\text { Age })_{\mathrm{t}-1}$ from the set of independent variables. Pseudo $\mathrm{R}^{2} \mathrm{w} / \mathrm{o}$ precautionary saving is the pseudo $\mathrm{R}^{2}$ of the multinomial logit regression that excludes $R \& \mathrm{D}_{t-1}$, Industry Volatility $\mathrm{t}_{\mathrm{t}-1}$, and Dividend Payer $_{\mathrm{t}-1}$ from the set of independent variables. Pseudo $\mathrm{R}^{2} \mathrm{w} / \mathrm{o}$ tradeoff is the pseudo $\mathrm{R}^{2}$ of the multinomial logit regression that excludes Leverage $\mathrm{t}_{\mathrm{t}-1}$ from the set of independent variables. $* * *, * *$, and * indicates significance at the $1 \%, 5 \%$, and $10 \%$ level. 
Panel A: Coefficients and z-statistics

\begin{tabular}{|c|c|c|c|c|c|c|}
\hline \multirow[b]{2}{*}{ VARIABLES } & \multicolumn{2}{|c|}{ (1) All issuers } & \multicolumn{2}{|c|}{$\begin{array}{l}\text { (1) Issuers with } \\
\text { Cash } \\
\text { ex post } \leqslant 0\end{array}$} & \multicolumn{2}{|c|}{$\begin{array}{l}\text { (3) Issuers with } \\
\text { Cash }_{\text {ex ante }} \leqslant 0\end{array}$} \\
\hline & Dual issues & $\begin{array}{c}\text { Pure equity } \\
\text { issue }\end{array}$ & Dual issues & $\begin{array}{l}\text { Pure equity } \\
\text { issue }\end{array}$ & Dual issues & $\begin{array}{c}\text { Pure equity } \\
\text { issue }\end{array}$ \\
\hline Cash $_{t-1} \div$ Assets $_{t-1}$ & $\begin{array}{l}0.45^{* * * *} \\
(2.61)\end{array}$ & $\begin{array}{l}1.55^{* * *} \\
(12.41)\end{array}$ & & & & \\
\hline $\mathrm{ICF}_{\mathrm{t}-1} \div$ Assets $_{\mathrm{t}-1}$ & $\begin{array}{l}-2.69 * * * \\
(-16.01)\end{array}$ & $\begin{array}{l}-1.74 * * * \\
(-12.45)\end{array}$ & & & & \\
\hline Investments $_{\mathrm{t}-1} \doteqdot$ Assets $_{\mathrm{t}-1}$ & $\begin{array}{l}1.72 * * * \\
(10.34)\end{array}$ & $\begin{array}{l}-0.25^{* *} \\
(-2.00)\end{array}$ & & & & \\
\hline Tobin's $\mathrm{Q}_{\mathrm{t}-1}$ & $\begin{array}{l}0.08^{* * * *} \\
(3.82)\end{array}$ & $\begin{array}{l}0.20^{* * * *} \\
(11.56)\end{array}$ & $\begin{array}{l}0.14 * * * \\
(5.87)\end{array}$ & $\begin{array}{l}0.29 * * * \\
(13.59)\end{array}$ & $\begin{array}{l}0.11 * * * \\
(3.80)\end{array}$ & $\begin{array}{l}0.25^{* * *} \\
(9.59)\end{array}$ \\
\hline Return $_{t-1}$ & $\begin{array}{l}0.29 * * * \\
(11.57)\end{array}$ & $\begin{array}{l}0.20 * * * \\
(9.65)\end{array}$ & $\begin{array}{l}0.21 * * * \\
(7.85)\end{array}$ & $\begin{array}{l}0.14 * * * \\
(5.75)\end{array}$ & $\begin{array}{l}0.25^{* * *} \\
(7.43)\end{array}$ & $\begin{array}{l}0.11^{* * *} \\
(3.70)\end{array}$ \\
\hline Return $_{t+1, t+3}$ & $\begin{array}{l}-0.10^{* * * *} \\
(-4.41)\end{array}$ & $\begin{array}{l}-0.06 * * * \\
(-5.08)\end{array}$ & $\begin{array}{l}-0.12 * * * \\
(-5.12)\end{array}$ & $\begin{array}{l}-0.12 * * * \\
(-6.08)\end{array}$ & $\begin{array}{l}-0.10 * * * \\
(-3.64)\end{array}$ & $\begin{array}{l}-0.05 * * * \\
(-3.35)\end{array}$ \\
\hline Term Spread $_{t-1}(\%)$ & $\begin{array}{l}0.12^{* * * *} \\
(2.62)\end{array}$ & $\begin{array}{c}0.01 \\
(0.18)\end{array}$ & $\begin{array}{l}0.13 * * * \\
(2.69)\end{array}$ & $\begin{array}{c}0.07 \\
(1.44)\end{array}$ & $\begin{array}{l}0.25^{* * * *} \\
(4.04)\end{array}$ & $\begin{array}{l}0.12^{* *} \\
(2.36)\end{array}$ \\
\hline Default Spread $_{\mathrm{t}-1}(\%)$ & $\begin{array}{l}0.41 * * * \\
(4.94)\end{array}$ & $\begin{array}{l}0.54 * * * \\
(10.00)\end{array}$ & $\begin{array}{l}0.34 * * * \\
(3.36)\end{array}$ & $\begin{array}{l}0.33^{* * * *} \\
(3.82)\end{array}$ & $\begin{array}{l}0.29 * * \\
(2.44)\end{array}$ & $\begin{array}{l}0.44 * * * \\
(5.08)\end{array}$ \\
\hline $\operatorname{Ln}(\text { Sales })_{t-1}$ & $\begin{array}{l}-0.11 * * * \\
(-6.90)\end{array}$ & $\begin{array}{l}-0.14 * * * \\
(-12.14)\end{array}$ & $\begin{array}{l}-0.16^{* * *} \\
(-9.94)\end{array}$ & $\begin{array}{l}-0.26^{* * *} \\
(-17.29)\end{array}$ & $\begin{array}{l}-0.19 * * * \\
(-9.67)\end{array}$ & $\begin{array}{l}-0.20^{* * *} \\
(-12.28)\end{array}$ \\
\hline $\operatorname{Ln}(\text { Age })_{t}$ & $\begin{array}{l}-0.25 * * * \\
(-8.05)\end{array}$ & $\begin{array}{l}-0.13 * * * \\
(-5.79)\end{array}$ & $\begin{array}{l}-0.26 * * * \\
(-7.89)\end{array}$ & $\begin{array}{l}-0.18 * * * \\
(-5.87)\end{array}$ & $\begin{array}{l}-0.28 * * * \\
(-6.70)\end{array}$ & $\begin{array}{l}-0.09 * * * \\
(-2.75)\end{array}$ \\
\hline Leverage $_{t-1}$ & $\begin{array}{l}1.02 * * * \\
(11.21)\end{array}$ & $\begin{array}{l}0.61 * * * \\
(7.78)\end{array}$ & $\begin{array}{l}1.20 * * * \\
(12.50)\end{array}$ & $\begin{array}{l}0.66^{* * * *} \\
(7.04)\end{array}$ & $\begin{array}{l}1.14 * * * \\
(9.80)\end{array}$ & $\begin{array}{l}0.62 * * * \\
(5.94)\end{array}$ \\
\hline$R \& D_{t-1}$ & $\begin{array}{l}1.21^{* * * *} \\
(4.19)\end{array}$ & $\begin{array}{l}2.03^{* * *} \\
(8.74)\end{array}$ & $\begin{array}{l}2.51 * * * \\
(7.77)\end{array}$ & $\begin{array}{l}2.93 * * * \\
(10.16)\end{array}$ & $\begin{array}{l}2.21 * * * \\
(6.08)\end{array}$ & $\begin{array}{l}2.79 * * * \\
(8.77)\end{array}$ \\
\hline Industry Volatility ${ }_{\mathrm{t}-1}$ & $\begin{array}{c}0.45^{*} \\
(1.81)\end{array}$ & $\begin{array}{l}0.84 * * * \\
(4.73)\end{array}$ & $\begin{array}{l}0.86^{* * * *} \\
(3.05)\end{array}$ & $\begin{array}{l}0.95^{* * * *} \\
(3.70)\end{array}$ & $\begin{array}{l}0.78^{* *} \\
(2.17)\end{array}$ & $\begin{array}{l}1.47 * * * \\
(5.27)\end{array}$ \\
\hline Dividend Payer ${ }_{t-1}$ & $\begin{array}{l}-0.19 * * * \\
(-3.28)\end{array}$ & $\begin{array}{l}-0.40 * * * \\
(-9.50)\end{array}$ & $\begin{array}{l}-0.15^{* *} \\
(-2.38)\end{array}$ & $\begin{array}{l}-0.22 * * * \\
(-3.82)\end{array}$ & $\begin{array}{l}-0.12 \\
(-1.43)\end{array}$ & $\begin{array}{l}-0.25 * * * \\
(-3.86)\end{array}$ \\
\hline Constant & $\begin{array}{l}-2.61 * * * \\
(-10.54)\end{array}$ & $\begin{array}{l}-1.36 * * * \\
(-7.67)\end{array}$ & $\begin{array}{l}-2.10 * * * \\
(-7.97)\end{array}$ & $\begin{array}{l}-1.01 * * * \\
(-4.21)\end{array}$ & $\begin{array}{l}-1.76 * * * \\
(-5.16)\end{array}$ & $\begin{array}{l}-1.25 * * * \\
(-4.54)\end{array}$ \\
\hline Industry dummies & Yes & & Yes & & Yes & \\
\hline Year dummies & Yes & & Yes & & Yes & \\
\hline Observations & 34,191 & & 22,948 & & 14,491 & \\
\hline Pseudo $\mathrm{R}^{2}(\%)$ & 17.54 & & 15.22 & & 13.73 & \\
\hline $\begin{array}{l}\text { Pseudo } \mathrm{R}^{2}(\%) \text { w/o year } \\
\text { dummy variables }\end{array}$ & 15.90 & & 13.50 & & 12.06 & \\
\hline $\begin{array}{l}\text { Pseudo } \mathrm{R}^{2}(\%) \text { w/o industry } \\
\text { dummy variables }\end{array}$ & 16.89 & & 14.51 & & 13.12 & \\
\hline Pseudo $\mathrm{R}^{2}(\%)$ w/o timing & 16.26 & & 13.46 & & 12.42 & \\
\hline Pseudo $\mathrm{R}^{2}(\%)$ w/o lifecycle & 16.92 & & 13.55 & & 12.50 & \\
\hline $\begin{array}{l}\text { Pseudo } \mathrm{R}^{2}(\%) \text { w/o } \\
\text { precautionary saving }\end{array}$ & 17.06 & & 14.60 & & 12.97 & \\
\hline Pseudo $\mathrm{R}^{2}(\%)$ w/o tradeoff & 17.27 & & 14.72 & & 13.30 & \\
\hline
\end{tabular}


Panel B. Economic effects (\%) of a 2 standard dev. change in the explanatory variable

\begin{tabular}{|c|c|c|c|c|c|}
\hline VARIABLES & $\begin{array}{c}\text { Pure debt } \\
\text { issue }\end{array}$ & $\begin{array}{c}\text { Dual } \\
\text { issues }\end{array}$ & $\begin{array}{l}\text { Pure equity } \\
\text { issue }\end{array}$ & $\begin{array}{c}\text { All debt } \\
\text { issues }\end{array}$ & $\begin{array}{l}\text { All equity } \\
\text { issues }\end{array}$ \\
\hline \multicolumn{6}{|l|}{ Regression (1): } \\
\hline $\operatorname{Cash}_{\mathrm{t}-1} \div$ Assets $_{\mathrm{t}-1}$ & -7.9 & -0.4 & 8.3 & -8.3 & 7.9 \\
\hline $\mathrm{ICF}_{\mathrm{t}-1} \div$ Assets $_{\mathrm{t}-1}$ & 12.6 & -5.8 & -6.7 & 6.8 & -12.5 \\
\hline Investments $_{\mathrm{t}-1} \div$ Assets $_{\mathrm{t}-1}$ & -1.4 & 3.7 & -2.3 & 2.3 & 1.4 \\
\hline Tobin's $\mathrm{Q}_{\mathrm{t}-1}$ & -8.4 & 0.1 & 8.3 & -8.3 & 8.4 \\
\hline Return $_{\mathrm{t}-1}$ & -8.0 & 3.4 & 4.6 & -4.6 & 8.0 \\
\hline $\operatorname{Return}_{\mathrm{t}+1, \mathrm{t}+3}$ & 3.9 & -1.9 & -2.0 & 2.0 & -3.9 \\
\hline $\operatorname{Term~Spread~}_{\mathrm{t}-1}(\%)$ & -1.5 & 2.1 & -0.6 & 0.6 & 1.5 \\
\hline Default Spread $_{t-1}(\%)$ & -8.6 & 1.6 & 7.0 & -7.0 & 8.6 \\
\hline $\operatorname{Ln}(\text { Sales })_{t-1}$ & 9.4 & -1.7 & -7.6 & 7.7 & -9.3 \\
\hline $\operatorname{Ln}(\text { Age })_{t}$ & 4.6 & -2.6 & -2.0 & 2.0 & -4.6 \\
\hline Leverage $_{t-1}$ & -6.0 & 3.0 & 3.0 & -3.0 & 6.0 \\
\hline $\mathrm{R} \& \mathrm{D}_{\mathrm{t}-1}$ & -7.4 & 0.8 & 6.5 & -6.6 & 7.3 \\
\hline Industry Volatility $_{\mathrm{t}-1}$ & -3.8 & 0.3 & 3.5 & -3.5 & 3.8 \\
\hline Dividend Payer $r_{t-1}$ & 5.9 & -0.4 & -5.5 & 5.5 & -5.9 \\
\hline \multicolumn{6}{|l|}{ Regression (2): } \\
\hline Tobin's $Q_{t-1}$ & -10.2 & 1.6 & 8.6 & -8.6 & 10.2 \\
\hline Return $_{\mathrm{t}-1}$ & -5.5 & 3.3 & 2.1 & -2.2 & 5.4 \\
\hline Return $_{t+1, t+3}$ & 6.0 & -2.6 & -3.5 & 3.4 & -6.1 \\
\hline Term Spread $_{\mathrm{t}-1}(\%)$ & -3.4 & 2.5 & 0.9 & -0.9 & 3.4 \\
\hline Default Spread $_{t-1}(\%)$ & -5.0 & 2.3 & 2.7 & -2.7 & 5.0 \\
\hline $\operatorname{Ln}(\text { Sales })_{t-1}$ & 14.2 & -3.6 & -10.5 & 10.6 & -14.1 \\
\hline $\operatorname{Ln}(\text { Age })_{t}$ & 5.9 & -3.5 & -2.4 & 2.4 & -5.9 \\
\hline Leverage $_{t-1}$ & -6.7 & 4.7 & 2.0 & -2.0 & 6.7 \\
\hline $\mathrm{R} \& \mathrm{D}_{\mathrm{t}-1}$ & -8.8 & 3.4 & 5.4 & -5.4 & 8.8 \\
\hline Industry Volatility $_{\mathrm{t}-1}$ & -3.9 & 1.6 & 2.3 & -2.3 & 3.9 \\
\hline Dividend Payer $_{\mathrm{t}-1}$ & 3.1 & -0.9 & -2.2 & 2.2 & -3.1 \\
\hline \multicolumn{6}{|l|}{ Regression (3): } \\
\hline Tobin's $Q_{t-1}$ & -10.9 & 0.6 & 10.3 & -10.3 & 10.9 \\
\hline Return $_{\mathrm{t}-1}$ & -5.2 & 3.7 & 1.5 & -1.5 & 5.2 \\
\hline Return $_{t+1, t+3}$ & 4.0 & -2.6 & -1.5 & 1.4 & -4.1 \\
\hline Term Spread $_{\mathrm{t}-1}(\%)$ & -6.8 & 4.6 & 2.2 & -2.2 & 6.8 \\
\hline Default Spread $_{t-1}(\%)$ & -7.4 & 1.3 & 6.1 & -6.1 & 7.4 \\
\hline $\operatorname{Ln}(\text { Sales })_{t-1}$ & 14.7 & -4.8 & -9.8 & 9.9 & -14.6 \\
\hline $\operatorname{Ln}(\text { Age })_{t}$ & 4.8 & -4.2 & -0.6 & 0.6 & -4.8 \\
\hline Leverage $_{t-1}$ & -7.2 & 4.5 & 2.7 & -2.7 & 7.2 \\
\hline $\mathrm{R} \& \mathrm{D}_{\mathrm{t}-1}$ & -11.1 & 2.8 & 8.3 & -8.3 & 11.1 \\
\hline Industry Volatility $\mathrm{t}_{\mathrm{t}-1}$ & -6.4 & 0.7 & 5.7 & -5.7 & 6.4 \\
\hline Dividend Payer $_{\mathrm{t}-1}$ & 3.8 & -0.3 & -3.4 & 3.5 & -3.7 \\
\hline
\end{tabular}

